
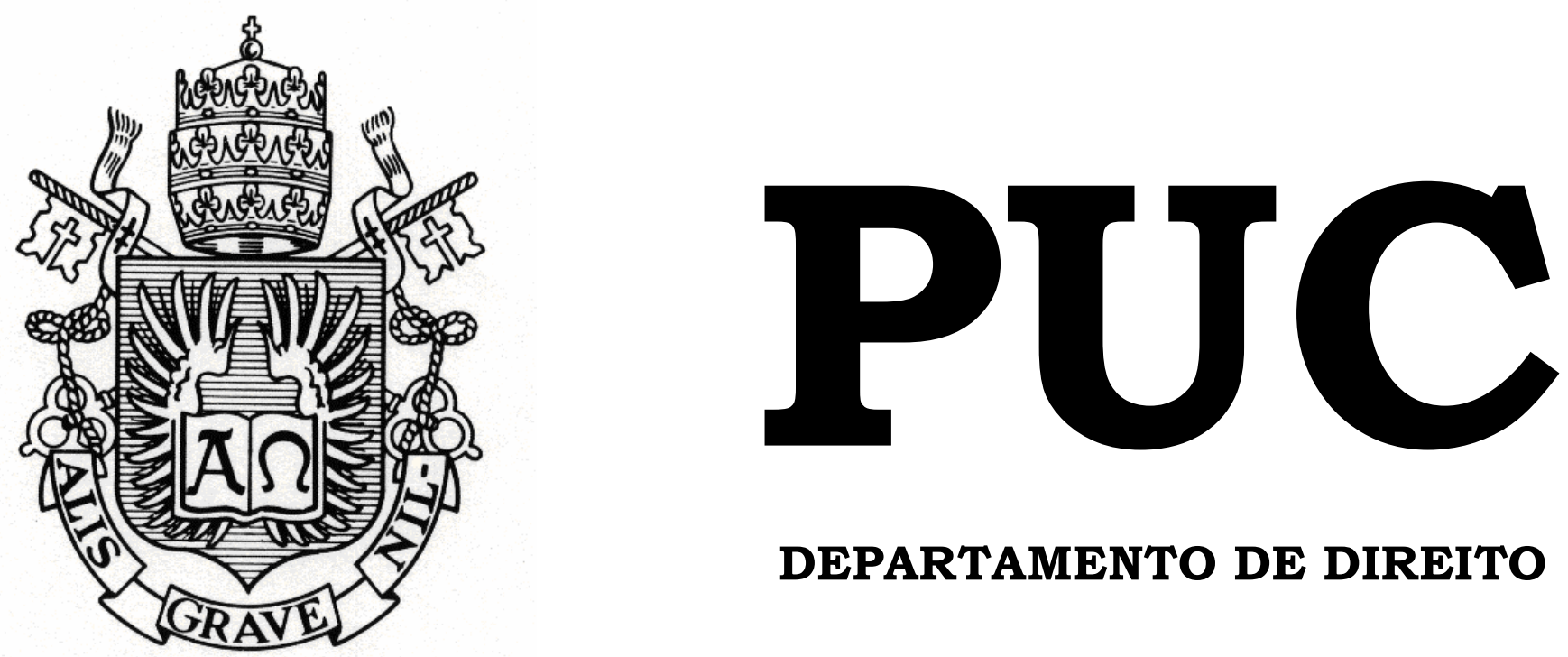

DEPARTAMENTO DE DIREITO

\title{
RESPONSABILIDADE CIVIL PELO DANO AMBIENTAL: PROBLEMÁTICA REFERENTE CONCEITO DE POLUIDOR INDIRETO
}

por

GABRIELA BERRO MARINS

ORIENTADOR(A): DANIELLE DE A. MOREIRA

2007.2

PONTIFÍCIA UNIVERSIDADE CATÓLICA DO RIO DE JANEIRO

RUA MARQUÊS DE SÃO VICENTE, 225 - CEP 22453-900

RIO DE JANEIRO - BRASIL 


\title{
RESPONSABILIDADE CIVIL PELO DANO AMBIENTAL: PROBLEMÁTICA REFERENTE AO CONCEITO DE POLUIDOR INDIRETO
}

\author{
por
}

GABRIELA BERRO MARINS

Monografia

apresentada

ao

Departamento de Direito da Pontificia Universidade Católica do Rio de Janeiro (PUC-Rio) para a obtenção do Título de Bacharel em Direito.

Orientador(a): Danielle de A. Moreira 
Ao meu pai, com amor, por todas as lições de vida que me deixou. 


\section{Agradecimentos}

A minha mãe Beatriz e ao meu pai Carlos, pelo apoio, incentivo, cuidados, compreensão, esforço, carinho e amor.

À minha orientadora, Professora Danielle de A. Moreira, pela paciência, amizade, grandeza intelectual e, sobretudo, pela orientação competente, imprescindível para a realização desta monografia.

Ao Professor Fernando Walcacer e aos companheiros de NIMAJUR, pela riqueza dos debates.

Aos amigos: Thiago Franco, Sarah Braga, Rafaella Braga e João Alvarez, pelo companheirismo ao longo desta trajetória.

Aos amigos: Tamara Sanches, Pedro Peixoto, Patrícia Xavier, Gabriela Mourelle, Jimena Leon, Frederico Cavalcanti, Fernanda e Renata Cruz e Luisa Schuback, pelo carinho ao longo da vida.

Devo, ainda, palavras de agradecimento aos funcionários do Departamento de Direito da PUC-RJ. 


\section{Resumo}

MARINS, Gabriela Berro. Responsabilidade civil pelo dano ambiental: problemática referente ao conceito de poluidor indireto. Rio de Janeiro. 112 p. 2007. Monografia de final de curso - Departamento de Direito, Pontifícia Universidade Católica do Rio de Janeiro.

$\mathrm{O}$ direito ao meio ambiente ecologicamente equilibrado, fruto de uma evolução de direitos e de uma revisão de paradigmas em que a ética antropocêntrica, contrapondo-se à ética biocêntrica, passa a ser discutida, vem em resposta a necessidades do homem do final do século $\mathrm{XX}$, nascendo a percepção de que o desenvolvimento não pode se dar a qualquer custo e, muito menos, em detrimento à vida, humana ou não. Assim, diversos instrumentos são utilizados visando a proteção de tal bem, autonomamente considerado, dentre eles, a responsabilidade civil. Todavia, devido a dificuldades em sua implementação e tendo em vista as peculiaridades do bem jurídico tutelado e do dano ambiental, tal instituto sofre adaptações. A adoção do regime da responsabilidade objetiva, baseada na teoria do risco, e a ampliação do rol de sujeitos passivos da ação reparatória ambiental, incluindo o poluidor indireto, se, por um lado, garantem a reparação do dano, por outro, acabam por trazer grande

insegurança jurídica tendo em vista a possibilidade de se chegar a uma responsabilização infinita de acordo com a modalidade do risco adotado e a teoria do nexo causal escolhida. O presente trabalho pretende, assim, analisar a problemática relacionada ao conceito de poluidor indireto no que concerne à responsabilidade civil pelo dano ambiental.

\section{Palavras - chave}

Meio Ambiente. Dano ambiental. Responsabilidade civil ambiental. Poluidor indireto. 


\section{Sumário}

Introdução. 6

1. Tutela jurídica do Meio Ambiente e os princípios inerentes ao Direito Ambiental.......................................... 10

1.1 A evolução normativa........................................................... 10

1.2 A Constituição Federal de 1988, a Política Nacional de Meio Ambiente e os Princípios Inerentes ao Direito Ambiental ...12

2 Responsabilidade Civil Ambiental............................... 29

2.1 Fundamentos legais e Funções da Responsabilidade Civil

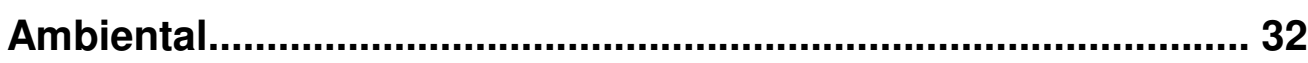

2.2 Pressupostos da Responsabilidade Ambiental.................... 38

2.2.1 O Dano Ambiental......................................................... 41

2.2.2 Nexo de Causalidade................................................... 47

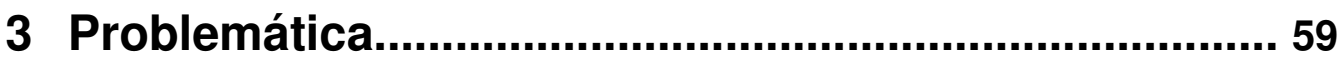

4 A Responsabilidade Civil Ambiental do Poluidor

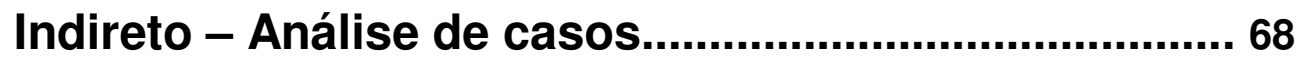

4.1 A co-responsabilidade dos poluidores indiretos …..............68

4.2 A co-responsabilidade das instituições financeiras por danos ambientais..................................................................... 72

4.3 Responsabilidade do Poder Público....................................... 76

4.4 A responsabilidade da agroindústria diante do dano ambiental originado no âmbito da propriedade do produtor integrado

4.5 A responsabilização dos produtores e fornecedores pela destinação final dos resíduos: a responsabilidade pósconsumo 93

Conclusão.............................................................................99

Referências Bibliográficas........................................... 102 


\section{Introdução}

O presente pretende analisar a problemática relacionada ao conceito de poluidor indireto no que concerne à responsabilidade civil pelo dano ambiental.

Conforme ensina José Luis Serrano Moreno, pode-se perceber no sistema jurídico "un impacto de la crisis ecológica en el derecho, un impacto legal sobre la crisis ecológicas y una crisis ecológica susceptible de ser leída en el interior del sistema jurídico". ${ }^{1}$

Trata-se, portanto, de premissa inegável que o direito ao meio ambiente ecologicamente equilibrado vem em resposta a necessidades do homem do final do século XX, sendo considerado fruto de uma evolução de direitos e de uma revisão de paradigmas em que a ética antropocêntrica, contrapondo-se à ética biocêntrica, passa a ser discutida. Nasce a percepção de que o desenvolvimento não pode se dar a qualquer custo e, muito menos, em detrimento à vida, humana ou não. Todavia, devido a dificuldades em sua implementação, a evolução do Direito Ambiental não ocorre de forma plena.

A Constituição Federal, em seu art. 225, dispõe que todos têm direito a um meio ambiente ecologicamente equilibrado, bem de uso comum do povo, essencial à sadia qualidade de vida, impondo à coletividade e ao Poder Público o dever de preservá-lo às presentes e futuras gerações.

Contudo, as características intrínsecas do Direito Ambiental e de seu objeto, meio ambiente entendido como macrobem, quais sejam o seu caráter difuso, supraindividual, indivisível e indisponível, fazem com que determinados instrumentos tenham sido adaptados para serem utilizados visando à efetiva proteção ambiental.

\footnotetext{
${ }^{1}$ SERRANO MORENO, José Luis. Cuatro métodos para leer el derecho ambiental. p.39 apud BORGES, Roxana Cardoso Brasileiro. Direito ambiental e Teoria Jurídica no final do século XX. In VARELLA, Marcelo Dias e BORGES, Roxana Cardodo (orgs.). O novo em Direito Ambiental. Belo Horizonte: Del Rey, 1998.
} 
Conforme leciona Álvaro Luiz Valery Mirra, a Carta Magna busca, em tal dispositivo, a proteção do “...meio ambiente globalmente considerado, entendido não só como mero agregado dos elementos da natureza acima indicados, mas principalmente como o conjunto de relações, interações e interdependências que se estabelecem entre todos os seres vivos uns com os outros (incluindo o homem) e entre eles o meio físico no qual vivem." ${ }^{2}$, abrangendo ainda o meio ambiente cultural.

De acordo com o mesmo autor ${ }^{3}$, a defesa do patrimônio cultural implica tanto a preservação do meio físico, compreendido pelos monumentos de valor histórico, turístico, paisagístico ou artístico e pela memória social e antropológica do homem.

Por sua vez, o dano ambiental, imensurável, transfronteiriço, intergeracional, sinergético e não necessariamente atual, se demonstra de difícil ou, na maioria das vezes, impossível reparação.

Devido à percepção de que os recursos ambientais não são infinitos e inesgotáveis e às peculiaridades do Direito Ambiental, principalmente no que diz respeito a) à difícil identificação dos sujeitos da relação jurídica obrigacional, b) à árdua tarefa quanto à determinação e valoração da lesão ao meio ambiente e c) à complexidade e ao caráter fluido do nexo causal, a responsabilidade civil tradicional sofreu adaptações de modo a alcançar a tão almejada reparação do dano.

Assim como difícil é a identificação das vítimas de um dano ambiental, também o é identificar as fontes da degradação, ou seja, os poluidores. Necessário se faz, portanto, que se amplie o rol de sujeitos passíveis de responsabilização para que, de modo a superar mais esta dificuldade, não quede o dano ambiental sem reparação, seja pela inexistência de sujeito passivo direto determinado na relação obrigacional, seja pela insolvência do poluidor direto.

\footnotetext{
${ }^{2}$ MIRRA, Álvaro Luiz Valery. Fundamentos do Direito Ambiental no Brasil. Revista dos Tribunais, São Paulo, v. 706, 1994. p.7

${ }^{3}$ Ibid. p.13
} 
Conceituado pelo art. $3^{\circ}$, inciso VI, da Lei $n^{\circ}$. 6.938/81, será poluidor a pessoa física ou jurídica de direito privado ou público, responsável direta ou indiretamente por atividade causadora de degradação ambiental, surgindo então a figura do poluidor indireto, que, de uma forma genérica, será aquele que de forma indireta contribui para o dano ambiental.

Tendo em vista a amplitude de tal conceito, é mister que se limite quem poderá ser responsabilizado pelos danos ambientais de forma a nortear aquele que busca a reparação do mesmo no momento da propositura de uma ação em juízo. Importa ressalvar que não se busca através deste deixar o dano ambiental irreparável. Tampouco, se almeja que a sociedade suporte o ônus tanto da reparação quanto da perda de um direito seu. O que se visa, apenas, é ressaltar a problemática referente ao conceito de poluidor indireto e realçar a necessidade de se impor limite ao mesmo, sob pena de se ter uma cadeia infinita de poluidores, gerando uma responsabilização infinita e, por vezes, injusta.

Para tanto, o primeiro capítulo abordará a tutela constitucional do meio ambiente fazendo uma análise dos princípios inerentes ao Direto Ambiental e pertinentes ao presente trabalho.

No tópico seguinte, será abordado o tema da responsabilidade civil demonstrando-se as peculiaridades existentes quando se trata de responsabilidade civil pelo dano ambiental e realizando ainda uma breve exposição sobre as teorias relacionadas à causalidade.

No terceiro capítulo, será abordada a problemática existente quanto à aplicação de tal instrumento e as dificuldades inerentes à reparação do dano ambiental, enfatizando, sobretudo, à questão do conceito de poluidor indireto.

Através do estudo de jurisprudência e doutrina existente sobre o assunto, em um quarto capítulo, será realizada análise de casos tendo em vista a busca pelos limites ao conceito de poluidor indireto.

Por fim, a partir das análises anteriores e, buscando-se uma maior segurança jurídica, sem pretensão de esgotar os debates acerca do assunto, 
procura-se demonstrar as dificuldades relacionadas à identificação de quem poderá ser considerado responsável pela reparação dos danos ambientais na condição de poluidor indireto. 


\section{Tutela Jurídica do Meio Ambiente e os princípios inerentes ao Direito Ambiental}

\subsection{A evolução normativa}

É inegável a importância da década de 70 no que diz respeito às questões ambientais. A Conferência da ONU em 1972, originando a Declaração de Estocolmo, abriu caminho para o posterior reconhecimento do meio ambiente ecologicamente equilibrado como direito fundamental a ser juridicamente tutelado. Todavia, a oposição do Brasil e de outros países em desenvolvimento quanto às diretrizes internacionais de controle à poluição, sob a justificativa que de a pior poluição seria pobreza, e que, por isso, o desenvolvimento a qualquer custo seria o necessário, marcou tal encontro.

Em 31.10.1981, sob a pressão imposta pela sociedade civil e internacional, editou-se a Lei ${ }^{\circ}$. 6938/81, a qual dispõe sobre a Política Nacional do Meio Ambiente, estabelecendo normas gerais de proteção ao meio ambiente.

Tal lei originou o art. 225 da Constituição Federal de 1988, acatando a idéia da estreita relação entre o equilíbrio os recursos ambientais e o desenvolvimento econômico.

Em junho de 1992, foi realizada no Rio de Janeiro a Conferência das Nações Unidas sobre o Meio Ambiente e Desenvolvimento, trazendo à tona a questão ambiental. Contrapondo-se ao conflito existente 20 anos antes, prevalecendo o ideal de cooperação, foram reafirmados os princípios estabelecidos em 1972 e incluiu-se ainda a idéia de desenvolvimento sustentável, combinando assim as aspirações, compartilhadas por todos os países, ao progresso econômico à necessidade de uma consciência ecológica, respondendo assim, ainda que tardiamente, às reivindicações de Estocolmo. 
De uma forma brilhante, Álvaro Luiz Valery Mirra ${ }^{4}$ faz uma analogia entre o Direito Ambiental Brasileiro e uma bacia hidrografia. Tal bacia corresponde a um rio principal e por seus afluentes.

O rio principal é formado pela Constituição Federal, pela Lei da Política Nacional do Meio Ambiente (Lei nº 6938/81), pelas Constituições dos Estados e pelas Declarações Internacionais de Princípios de Estocolmo de 1972 e do Rio de Janeiro de 1992.

Já seus afluentes constituem-se pela legislação ambiental setorial abarcando o Código Florestal, a Lei de Proteção à Fauna, legislação sobre poluição, legislação sobre parques ${ }^{5}$ dentre outras.

Como conseqüência, leciona o autor que, devido à apresentada modalidade de sistema, há um integração e interdependência permanente entre os elementos e normas da bacia. Por isso, não se pode dar efetiva proteção aos elementos setoriais sem a observância das disposições existentes na legislação mais ampla.

Tampouco, a proteção do meio ambiente globalmente considerado será eficaz sem a proteção dos elementos setoriais respeitando-se as normas a eles correspondentes.

Deste modo, em meio a leis esparsas que dificultam o conhecimento e a aplicação dos instrumentos legislativos do Direito Ambiental, embora destas se possa extrair um sistema coerente e lógico, balizadas pelo "rio principal", como nos ensina Mirra ${ }^{6}$, o paradigma do desenvolvimento a qualquer preço é modificado.

\footnotetext{
${ }^{4}$ Ibid. p. 11.

${ }^{5}$ Atualmente, tendo em vista que tal informação fora retirada do texto "Fundamentos do Direito Ambiental no Brasil", elaborado pelo autor em 1994, tem-se que a legislação sobre parques mencionada pelo autor, corresponde a atual Lei $n^{\circ}$. 9985/2000, a qual regulamenta o art. 225, $\S 1^{\circ}$, incisos I, II, III e VII, institui o sistema nacional das unidades de conservação (SNUC) e dá outras providências.

${ }^{6}$ MIRRA, Álvaro Luiz Valery. Op. Cit., p.11.
} 


\subsection{A Constituição Federal de 1988, a Política Nacional de Meio Ambiente e os Princípios Inerentes ao Direito Ambiental.}

Conforme demonstra Carlos Roberto de Siqueira Castro ${ }^{7}$, o constituinte de 1988, antes de chegar ao art. 225, trata difusamente da questão ambiental ao longo do texto, fazendo menção expressa ao tipificar a ação popular e a ação civil pública, enunciar as competências dos entes federativos, abrigar o ambiente de trabalho no conceito de meio ambiente, incluir os sítios de valor ecológico no patrimônio cultural brasileiro e ao declinar os princípios específicos da Ordem Econômica e Financeira.

Inserto no título "Da Ordem Social”, a Constituição Federal de 1998 dispensa um capítulo ao tratamento "Do Meio Ambiente", sendo inaugurado pelo artigo 225, caput, o qual dispõe que:

Todos têm direito ao meio ambiente ecologicamente equilibrado, bem de uso comum do povo e essencial à sadia qualidade de vida, impondo-se ao Poder Público e à coletividade o dever de defendê-lo e preservá-lo para as presentes e futuras gerações.

Deste modo, tem-se que o direito ao meio ambiente ecologicamente equilibrado, bem de uso comum do povo, é um direito fundamental reconhecido a uma quantidade indeterminada e indeterminável de pessoas, incluídas no rol de titulares, além da coletividade, as futuras gerações, evidenciando-se seu caráter difuso e supraindividual.

É direito fundamental ao passo que é forma de preservação da vida, direito inviolável de acordo com o art. $5^{\circ}$, caput, da $\mathrm{CF} / 88$, e da dignidade da pessoa humana, fundamento do Estado Democrático de Direito, tal qual previsto pelo art. $1^{\circ}$, inciso III, da Lei Maior. Além disto, é fator de transformação social na medida em que só há Estado Democrático de Direito se preservados os atributos essenciais da pessoa humana.

\footnotetext{
${ }^{7}$ BARROSO, Luís Roberto. A proteção do meio ambiente na Constituição Brasileira. O direito ambiental e o novo humanismo ecológico. Revista de Direito da Procuradoria Geral, Rio de Janeiro, n. 44, 1992. p. 51
} 
Há que se entender ainda que a $\mathrm{CF} / 88$ refere-se ao meio ambiente com um macrobem não se limitando aos bens corpóreos em sua individualidade. De acordo com o art. $3^{\circ}$, inciso I da L. 6938/81:

Art $3^{\circ}$ - Para os fins previstos nesta Lei, entende-se por:

I - meio ambiente, o conjunto de condições, leis, influências e interações de ordem física, química e biológica, que permite, abriga e rege a vida em todas as suas formas;

Poder-se perceber, deste modo, a existência da tutela a um bem jurídico autônomo entendido como um conjunto agregado de microbens que se inter-relacionam condicionando a vida em todas as suas formas, possuindo o macrobem natureza imaterial e incorpórea, insuscetível de apropriação $^{8}$.

Todavia, o que pode, eventualmente, ser apropriado, sobretudo para fins econômicos, são os elementos corpóreos que compõem o meio ambiente e possuem um regime jurídico próprio estando submetidos a uma legislação setorial.

Ainda assim, tal apropriação só pode ser dar de acordo com limitações e critérios previstos em lei e desde que tal utilização não leve à apropriação individual do meio ambiente como bem imaterial ${ }^{9}$.

Ademais, deve-se observar sempre o princípio do desenvolvimento econômico sustentável, previsto no art. 170, inciso VI da CF/88 de modo que a propriedade apenas subsistirá se obedecida e preservada sua função socioambiental, tal qual previsto nos arts. $5^{\circ}$, inciso XXIII, 170, inc. III e 186, inc. II da Constituição de 1988, beneficiando tanto a coletividade quanto o meio ambiente.

Tendo em vista seu caráter difuso e fundamental, o direito ao meio ambiente é indisponível, não cabendo a sua transação por particulares e, nem mesmo, pelo poder público o qual atua apenas como administrador - e não como proprietário - de um bem pertencente a toda a coletividade

\footnotetext{
${ }^{8}$ MIRRA, Álvaro Luiz Valery.Op. cit., p. 13.

${ }^{9}$ Id., Princípios fundamentais do direito ambiental. Revista de Direito Ambiental, São Paulo, n. 2, 1996. p. 56.
} 
orientando-se pelo princípio da indisponibilidade do interesse público na proteção do meio ambiente.

Constituindo idéias centrais de um sistema jurídico - dando ao mesmo um sentido lógico, harmônico, coerente e racional, permitindo a visualização global do sistema para uma melhor aplicação de suas normas os princípios, de acordo com os ensinamentos de Álvaro Luiz Valery Mirra $^{10}$, podem ser extraídos do ordenamento jurídico brasileiro, e, no que tange à matéria ambiental, principalmente da CF/88, da Lei $n^{\circ} .6938 / 81$, das Constituições Estaduais e, também, das Declarações Internacionais de Princípios, sendo diretrizes básicas que auxiliarão no entendimento e na identificação da coerência das normas que compõem o sistema legislativo ambiental.

Embora não haja classificação uniforme dos mesmos, serão evidenciados neste trabalho alguns deles, cuja apresentação mister se faz para uma melhor compreensão do tema abordado.

Do texto expresso pela Carta Magna, pode-se extrair os princípios da intervenção estatal obrigatória na preservação do meio ambiente e o princípio da supremacia do interesse público na defesa do mesmo.

Isto ocorre tendo em vista o poder-dever dado ao Poder Público de defender e proteger o meio ambiente, de acordo com disposto no caput e parágrafo $1^{\mathrm{o}}$ do art. 225 da $\mathrm{CF} / 88$, podendo-se utilizar, para tanto, instrumentos como (a) o licenciamento (art. $9^{\circ}$, inciso IV, da Lei $n^{\circ}$. 6938/81); (b) zoneamento (art. $9^{\circ}$, inciso II da Lei n ${ }^{\circ} .6938 / 81$ e arts. 21, IX; 30, VIII, 182 da CF/88); (c) estudo de impacto ambiental (art. 9º, III, L6938/81 e art. $225 \S 1^{\circ}$, IV da CF/88); (d) a educação ambiental (art. 225, $\S 1^{\text {o }}, \mathrm{VI}$ da CF) e (e) o poder de polícia. ${ }^{11}$

De acordo com Toshio Mukai ${ }^{12}$, o poder de polícia é o instrumento principal de defesa do meio ambiente pelo Estado, possuindo como meios

\footnotetext{
${ }^{10}$ Ibid. p. 51.

11 MICHELS, Ruanda Schlickmann. Instrumentos administrativos de prevenção ao dano ambiental. Revista de Direito Ambiental, São Paulo, n. 45, 2007. p.218 a 230

${ }^{12}$ MUKAI, Toshio. Direito Ambiental Sistematizado. 4. ed. Rio de Janeiro: Forense Universitária, 2002. p.42 a 46.
} 
de atuação (a) as ordens, proibições e restrições - autorizadas por leis administrativas que impõem as normas restritivas e as sanções -, (b) os alvarás, de licença ou de autorização - instrumentos preventivos de controle ambiental por excelência - e, por fim, (c) a fiscalização das atividades e bens sujeitos ao poder de polícia administrativa.

Conforme ensina Paulo Affonso Leme Machado ${ }^{13}$, o Poder Público passa a figurar como gestor que administra bens que não são dele, devendo, por isto, explicar convincentemente sua gestão através da prestação de contas à sociedade sobre a utilização dos bens de uso comum do povo. Os Estados passam, então, a ter a responsabilidade de um controle que apresente bons resultados, sendo considerados responsáveis pela ineficiência na implementação de sua legislação. A co-responsabilidade dos Estados atinge ainda seus entes políticos e funcionários de modo a evitar que os custos da ineficiência ou das infrações recaiam sobre a população contribuinte e não sobre os autores dos danos ambientais provocados.

Todavia, não é apenas ao Poder Público que se incumbe a responsabilidade pela proteção do meio ambiente. De acordo com o art. $1^{\circ}$, inciso II, da Lei Maior, à coletividade pertence o direito-dever de proteção e defesa de tal bem jurídico vez que a cidadania encontra-se como fundamento do Estado Democrático de Direito e seu efetivo exercício inclui, dentre outras práticas, a participação popular na proteção ao meio ambiente. Além disto, o próprio artigo 225, caput, impõe à sociedade o dever de atuar em tal sentido.

De acordo com MIRRA ${ }^{14}$, o direito brasileiro reconhece a existência três mecanismos de participação direta da população na proteção da qualidade ambiental. O primeiro deles é a participação no processo de criação do Direito Ambiental através da iniciativa popular nos procedimentos legislativos (art. 61, caput e $\$ 2$ da CF), da realização de referendos sobre leis (art. 14, inc. II as CF) e da atuação de representantes

\footnotetext{
${ }^{13}$ LEME MACHADO, Paulo Affonso. Direito Ambiental Brasileiro. $15^{\mathrm{a}}$ edição. São Paulo: Malheiros 2007. p. 98 a 103.

${ }^{14}$ MIRRA, Princípios..., op. cit., p. 57.
} 
da sociedade civil em órgãos colegiados dotados de poderes normativos ( $\mathrm{p}$. ex, o CONAMA - art. $6^{\circ}$ L. 6368/81).

Um segundo mecanismo é a participação na formulação e na execução de políticas ambientais por intermédio de representantes da sociedade civil em órgãos colegiados e pelo acompanhamento da execução de políticas públicas, na realização de plebiscitos e na discussão de estudos de impacto ambiental em audiências públicas.

Tem-se ainda, como terceiro mecanismo, a intervenção através do Poder Judiciário utilizando-se instrumentos processuais que permitam a obtenção da prestação jurisdicional na área ambiental. Como exemplo, há a ação civil pública ambiental, prevista pela Lei no ${ }^{\circ} \cdot 7.347 / 85^{15}$.

Como pressupostos de tal participação, temos a informação, direito de todos previsto pelo art. $5^{\circ}$, incs. XIV, XXXIII e XXXIV da CF, art. 14, inciso I do Decreto 99.274/90 e art. $8^{\circ}$ da Lei n ${ }^{\circ}$. 7.347/85.

Paralelo a este direito, há dever de o poder público informar periodicamente à população sobre as ocorrências ambientais importantes e sobre o estado do meio ambiente dando publicidade aos atos praticados, tal qual previsto pelos arts. $4^{\circ}$, inciso $\mathrm{V}$, e $9^{\circ}$, incisos. $\mathrm{X}$ e XI, da Lei $\mathrm{n}^{\circ}$. 6.938/81, e art. $6^{\circ}$ da Lei $n^{\circ} .7 .347 / 85$, e a educação, prevista nos arts. 225, $\S 1^{\circ}$, inciso VI, da CF e art. $2^{\circ}$, inciso X, da Lei 6.938/81.

Traduzindo a realidade segundo a qual os danos ambientais são em regra de difícil, ou até mesmo impossível, reparação devido ao caráter frequentemente irreversível dos prejuízos causados ao meio ambiente e dos limites inerentes aos mecanismos de reparação deste tipo de dano, há ainda a) os princípios da precaução e da prevenção de danos e degradações ambientais, que preconizam a atenção do Direito Ambiental ao momento anterior à consumação do dano e b) o princípio do poluidor-pagador o qual possui efeito preventivo e curativo, atuando também em momento posterior à consumação do dano.

\footnotetext{
${ }^{15}$ Ibid. p. 58
} 
Assim, demonstra o autor Paulo Affonso Leme Machado que "o dever jurídico de evitar a consumação de danos ao meio ambiente vem sendo salientado em convenções, declarações e sentenças de tribunais internacionais, como na maioria das legislações internacionais" ${ }^{16}$. Tais convenções apontam para a necessidade de se prever, prevenir e evitar, na origem, as transformações prejudiciais ao meio ambiente e, consequentemente, à saúde humana.

"Prevenir", cuja raiz latina significa agir antecipadamente, consiste, primeiramente, em se conhecer o que prevenir para, após, tomar as medidas cabíveis de modo a evitar a conhecida possibilidade de ocorrência de um dano ambiental. Paulo Affonso Leme Machado, ensina que não há prevenção, todavia, sem informação organizada e sem pesquisa, dividindo, em cinco itens a aplicação do princípio da prevenção:

$1^{\circ}$ ) identificação e inventário das espécies animais e vegetais de um território, quanto à conservação da natureza e identificação das fontes contaminantes das águas e do mar, quanto ao controle da poluição; $2^{\circ}$ ) identificação e inventário dos ecossistemas, com a elaboração de um mapa ecológico; $3^{\circ}$ ) planejamentos ambiental e econômico integrados; $4^{\circ}$ ) ordenamento territorial ambiental para a valorização das áreas de acordo com a sua aptidão; e $5^{\circ}$ ) Estudo de impacto ambiental. ${ }^{17}$

Torna-se importante, portanto, a realização do Estudo de Impacto Ambiental de modo que, diagnosticados os riscos existentes, se possa ponderar sobre os meios de se evitar o prejuízo. Contudo, os meios a serem utilizados para a realização da prevenção podem variar de acordo com o desenvolvimento do país ou das tecnologias disponíveis ${ }^{18}$.

No Brasil, o art. $2^{\circ}$ da Lei $n^{\circ}$. 6.938/81, ao dispor em seus incisos IV e X que a Política Nacional do Meio Ambiente observará como princípios a "proteção dos ecossistemas, com a preservação de áreas representativas" e "a proteção das áreas ameaçadas de degradação", indica, de forma

\footnotetext{
${ }^{16}$ LEME MACHADO, op. cit., p. 82

${ }^{17}$ Ibid. p. 84

${ }^{18}$ Ibid. p. 84
} 
específica onde aplicar-se o princípio da prevenção ${ }^{19}$. Além disto, inserindo como objetivos de tal política "a compatibilização do desenvolvimento econômico-social com a preservação da qualidade do meio ambiente e do equilíbrio ecológico e a preservação dos recursos ambientais, com vistas à sua utilização racional e disponibilidade permanente (art. $4^{\circ}$, I e VI)" ${ }^{20}$, o princípio da prevenção passa a ter fundamento no Direito Positivo nesta lei pioneira na América Latina.

Conseguinte, incontestável é a obrigação de prevenir ou evitar o dano ambiental da forma mais eficiente possível quando o mesmo puder ser detectado antecipadamente protegendo tanto as presentes quanto as futuras gerações.

Todavia, nem sempre há a certeza científica acerca da existência do risco da ocorrência de um dano. Ainda assim, de acordo com o Princípio 15 da Declaração do Rio de Janeiro, votada na Conferência das Nações Unidas para o Meio Ambiente e o Desenvolvimento, em 1992,

de modo a proteger o meio ambiente, o princípio da precaução deve ser amplamente observado pelos estados de acordo com suas capacidades. Quando houver ameaça de danos sérios ou irreversíveis, a ausência de absoluta certeza científica não deve ser utilizada como razão para postergar medidas eficazes e economicamente viáveis para prevenir a degradação ambiental.

Do latim precautio-onis, precaução significa cautela antecipada, caracterizando-se pela ação antecipada diante da incerteza quanto à existência de risco ou perigo não se aguardando que esta se torne certeza. A precaução visa gerir a espera de informação, nascendo da diferença temporal entre a necessidade de uma ação imediata e o momento de modificação do conhecimento científico protegendo-se contra os riscos possíveis.

Sobre o assunto, afirma Álvaro Mirra que

mesmo que haja controvérsias no plano científico com relação aos efeitos nocivos de determinadas atividades sobre o meio ambiente, em atenção ao princípio da precaução, essas atividades deverão ser evitadas ou rigorosamente controladas. ${ }^{21}$

\footnotetext{
${ }^{19}$ Ibid. p. 84

${ }^{20}$ Ibid. p. 63 e 64

${ }^{21}$ MIRRA, Fundamentos..., op. cit., p.17 e 18.
} 
Deste modo, as medidas de precaução não devem ser postergadas tendo em vista que a pressa e a rapidez insensatas, correntes na sociedade contemporânea, devem ser suplantadas por tal princípio evitando-se o dano ambiental através da prevenção realizada no tempo correto.

Ressalta-se, contudo, que o princípio da precaução não visa a evitar a audácia saudável, e nem imobilizar as atividades humanas "mas se materializa na busca da segurança do meio ambiente e da continuidade da vida" ${ }^{22}$. Visa-se, portanto, à durabilidade da sadia qualidade de vida das gerações humanas e a continuidade da natureza existente no planeta.

Ao Poder Público, conforme leciona Machado, incumbe também as medidas de precaução de modo que

a necessidade do adiamento das medidas de precaução em acordos administrativos ou em acordos efetuados pelo Ministério Público deve ser exaustivamente provada pelo órgão público ambiental ou pelo próprio Ministério Público. Na dúvida, opta-se pela solução que proteja imediatamente o ser humano e conserve o meio ambiente (in dubio pro salute ou in dubio pro natura) ${ }^{23}$.

Tal princípio deve ainda ser aplicado pela Administração pública no cumprimento dos princípios expostos pelo art. 37, caput, da CF/88 legalidade, impessoalidade, moralidade, publicidade e eficiência - tendo em vista que

contraria a moralidade e a legalidade administrativas o adiamento de medidas de precaução que devam ser tomadas imediatamente. Violam o princípio da publicidade e o da impessoalidade administrativas os acordos e/ou licenciamentos em que o cronograma da execução de projetos ou execução de obras não são apresentados previamente ao público, possibilitando que setores interessados possam participar do procedimento das decisões ${ }^{24}$.

O princípio da precaução entra então no domínio do poder de polícia da administração podendo, em nome do mesmo, ser suspensa determinada liberdade ainda que tal decisão não possa ser apoiada em uma certeza científica. Conforme demonstra Denise Hammerschmidt,

a precaução estende seus efeitos permitindo em seu nome denegar uma autorização ou impor prescrições adicionais à difusão de novos produtos, técnicas,

\footnotetext{
${ }^{22}$ LEME MACHADO, op. cit., p. 77.

${ }^{23}$ Ibid. p. 77

${ }^{24}$ Ibid. p. 78
} 
procedimentos ou à implementação de um projeto em razão do grau de incerteza de que sejam portadores ${ }^{25}$.

Assim, a Administração Publica que, possuindo mecanismos para tanto, deixa de prevenir os danos ao meio ambiente e ao ser humano, omitindo-se quanto à exigência e à prática de medidas de precaução, ocasionando prejuízos, será considerada co-responsável pelos mesmos, devendo ser aplicadas medidas de responsabilização cabíveis.

Visando ainda a precaver-se quanto à existência de riscos da ocorrência de danos ambientais, utiliza-se como medida, a inversão do ônus da prova, impondo-se ao autor potencial provar, com anterioridade, e sem sombra de dúvida, que sua ação não é efetiva ou potencialmente degradante da qualidade ambiental, vez que são eles que pretendem alterar o status quo ambiental. Consequentemente, para que não sejam adotadas medidas corretivas ou preventivas, necessária será a comprovação por parte dos empreendedores de que tal atividade não danifica de forma irreversível ou, até mesmo, de forma grave, o meio ambiente, provando, portanto, que os limites dos riscos e das incertezas não foram ultrapassados.

De acordo com Mirra ${ }^{26}$, a adoção de tal posicionamento tem motivo simples: "como se constata frequentemente, uma vez consumada uma degradação ambiental, a sua reparação é sempre incerta e, quando possível, excessivamente custosa" ${ }^{27}$ de modo que, em determinadas hipóteses, no dia em que se puder ter certeza absoluta dos efeitos prejudiciais das atividades questionadas, os danos por ela provocados ao meio ambiente poderão ter proporção tamanha que inviabilize a sua reparação ou reversão. Nestes casos, a cessação de atividades potencialmente degradantes mesmo que diante de controvérsias científicas com relação a seus efeitos nocivos, é a única forma de se evitar danos de tamanha magnitude, cumprindo-se o

\footnotetext{
${ }^{25}$ HAMMERSCHMIDT, Denise. O risco na sociedade contemporânea e o princípio da precaução no direito ambiental. Revista de Direito Ambiental, São Paulo, n. 31, 2003. p. 146.

${ }^{26}$ MIRRA, Princípios..., op. cit., p. 62

${ }^{27}$ Id. Direito Ambiental: o princípio da precaução e sua aplicação judicial. Revista de Direito Ambiental, São Paulo, n. 21, 2001.p. 92 e 93.
} 
disposto no art. 225 da CF quando dispõe como direito das futuras gerações o meio ambiente ecologicamente equilibrado.

A consagração do princípio da precaução impôs, em definitivo, a adoção do enfoque da prudência e da vigilância, em detrimento do enfoque da tolerância, na aplicação do Direto Ambiental às condutas lesivas ao meio ambiente, estendendo-se sua aplicação até o judiciário. Este deverá julgar procedente a ação coletiva em defesa do meio ambiente diante de elementos indiciários quanto à ocorrência efetiva ou potencial de degradação ambiental, amparados cientificamente ou demonstrados, que não forem contrariados pelo degradados. ${ }^{28}$

Em síntese, em nome do princípio da precaução, o conflito de interesses econômicos com interesses ambientais deverá sempre ser decidido em prol do meio ambiente (in dubio pro natura).

Além dos princípios mencionados, há o princípio do poluidorpagador (PPP), expresso no art. 16 da Declaração do Rio de Janeiro de 1992, que, de acordo com José Rubens Morato Leite, sinteticamente, visa “à internalização dos custos externos de deterioração ambiental” 29 resultando, na medida em que a cautela estaria presente em situações de potencial poluição, em maior precaução e prevenção. ${ }^{30}$

Em seu aspecto econômico, como leciona o referido autor,

tem ligações subjacentes ou como auxiliar ao instituto da responsabilidade, pois é um princípio multifuncional na medida em que visa à precaução e à prevenção de atentados ambientais e também à redistribuição dos custos da poluição. ${ }^{31}$

Tal princípio vem contemplado no direito brasileiro pelo art. $4^{\circ}$, inciso VII, da Lei nº. 6938/81, o qual prevê a instituição de contribuições pela utilização de recursos ambientais. No mesmo sentido, a Lei $n^{\circ}$. 9.433/97 prevê a cobrança pela utilização de recursos hídricos. Ressalva

\footnotetext{
${ }^{28}$ Ibid.p. 102

${ }^{29}$ LEITE, José Rubens Morato. Dano Ambiental: do individual ao coletivo extrapatrimonial. São Paulo: Editora Revista dos Tribunais, 2000. p. 58.

${ }^{30}$ Princípio 16 em sua íntegra: As autoridades nacionais deverão esforçar-se por promover a internalização dos custos ambientais e a utilização de instrumentos econômicos, tendo em conta o princípio de que o poluidor deverá, em princípio, suportar o custo da poluição, com o devido respeito pelo interesse público e sem distorcer o comércio e investimento internacionais.

${ }^{31}$ LEITE, op. cit., p. 58.
} 
Bessa Antunes ${ }^{32}$ que, em ambos os casos, o PPP mescla-se com o princípio da compensação pela utilização dos recursos ambientais estando ambos longe de terem atingido a maturidade.

De acordo com Benjamin ${ }^{33}$, tal princípio também foi contemplado pela Constituição Federal, fazendo referência a Fiorillo e Abelha $^{34}$, os quais, ao determinar a sujeição dos poluidores, pessoas físicas ou jurídicas, às sanções administrativas e penais, independentemente da obrigação de reparar os danos causados, anotam que o parágrafo $3^{\circ}$ do art.225, abraçou o PPP.

Steigleder também partilha do mesmo entendimento apontando o acolhimento do PPP pelos $\S \S 2^{\circ}$ e $3^{\circ}$ da Carta Magna na medida em que se referem à responsabilização por danos ambientais e à obrigação de recuperar o meio ambiente em virtude de degradação ambiental decorrente da mineração. ${ }^{35}$

Primeiramente, há que se ressaltar que os recursos ambientais são escassos e que seu uso na produção e no consumo acaba por acarretar-lhe degradação e redução ${ }^{36}$. Além disto, a existência de recursos naturais gratuitos, sem que seja imputado um ônus pela utilização dos mesmos, leva, inexoravelmente, a uma situação de degradação ambiental ${ }^{37}$.

Consequentemente, nas palavras de Paulo de Bessa Antunes, "se o custo da redução dos recursos naturais não for considerado no sistema de preços, o mercado não será capaz de refletir a escassez" ${ }^{38}$, sendo necessária a adoção de políticas públicas capazes de eliminar as falhas de mercado assegurando que os custos ambientais estejam refletidos nos preços dos produtos.

\footnotetext{
32 ANTUNES, Paulo de Bessa. Dano Ambiental: Uma Abordagem conceitual. Rio de Janeiro: Editora Lumen Juris, 2000. p. 222.

${ }^{33}$ BENJAMIN, Antônio Herman. Responsabilidade civil pelo dano ambiental. Revista de Direito Ambiental, São Paulo, v.9, ano3, jan./mar. 1998. p. 18.

${ }^{34}$ Antonio Herman Benjamin faz menção aos autores Celso Antonio Pacheco Fiorillo e Marcelo Abelha Rodrigues.

${ }^{35}$ STEIGLEDER, Annelise Monteiro. Responsabilidade civil ambiental: as dimensões do dano ambiental no Direito Brasileiro. Porto Alegre: Livraria do Advogado Editora, 2004. p. 194.

${ }^{36}$ ANTUNES, op. cit., p. 219.

${ }^{37}$ LEITE, op. cit,. p. 58.

${ }^{38}$ ANTUNES,op. cit., p. 219 e 220.
} 
De fato, durante os processos produtivos nota-se a existência de externalidades negativas as quais ocorrem, de acordo com Bessa Antunes quando "a produção ou o consumo de determinado bem, por um indivíduo ou empresa, afeta diretamente os interesses de outro indivíduo ou empresa" 39. O dano ambiental, conforme demonstra, é um caso típico de tal externalidade.

O objetivo, portanto, segundo Morato Leite, é "fazer com que os custos sociais das medidas de proteção sejam impostos a quem inicialmente provocou a poluição" ${ }^{40}$ fazendo com que o custo adicional à sociedade seja corrigido na medida em que haja a sua internalização. Então, passa o poluidor a arcar com os custos necessários à eliminação, neutralização ou diminuição dos danos.

De acordo com Bessa Antunes ${ }^{41}$, a idéia principal do PPP é que a sociedade não pode arcar com os custos de uma atividade que beneficia apenas um indivíduo ou grupo de indivíduos buscando-se uma medida de justiça fundada na solidariedade e não na responsabilidade.

Deste modo, o PPP é um princípio de proteção do Direto Ambiental que procura imputar os custos da poluição ao poluidor. Inicialmente, tal princípio limitava-se a impor ao poluidor os custos das medidas de prevenção e de luta contra a poluição nos limites estabelecidos pela legislação do Estado. Contudo, os custos passaram a abranger ainda todos os custos ligados a poluição, incluindo os referentes à reparação dos danos e das indenizações dele decorrentes, conforme nos ensina Rangel Barbosa e Patrícia Oliveira ${ }^{42}$.

Tem-se, então, que é um princípio econômico de proteção ambiental que faz com que o poluidor internalize os custos da prevenção, da luta contra a poluição, bem como os da reparação dos danos que,

\footnotetext{
${ }^{39}$ Ibid. p. 214.

${ }^{40}$ LEITE, op. cit., p. 59.

${ }^{41}$ ANTUNES, op. cit., p. 222.

42 BARBOSA, Rangel; OLIVEIRA, Patrícia. O princípio do poluidor-pagador no protocolo de Quioto. Revista de Direito Ambiental, São Paulo, n. 44, 2006. p. 121 a 123.
} 
eventualmente, causar ao meio ambiente, não se restringindo à compensação dos danos causados pela poluição.

Todavia, não se trata de uma autorização a quem paga para poluir. $\mathrm{O}$ que se busca é, através de um preço alto de internalização, atuando de forma preventiva e repressiva, a utilização dos recursos ambientais de forma responsável desencorajando o exercício de atividades poluentes.

Esta atuação preventiva ocorre na medida em que o estabelecimento de um custo ambiental adiciona uma variável a ser analisada pelo empreendedor que passa a analisar a possibilidade de não utilizar o recurso. A inserção de tal variável reflete ainda na eficiência da empresa tendo em vista que empresas mais eficientes possuem custos menores. Soma-se a isso a precisa noção pelos consumidores e concorrentes dos níveis de cuidados ambientais e da existência de subsídios às atividades realizadas.

$\mathrm{Na}$ verdade, demonstra Morato Leite ${ }^{43}$, este princípio não soluciona a totalidade dos problemas econômicos ambientais tendo em vista a existência de grandes obstáculos no que tange à valoração dos custos das externalidades. Além disto, refere-se à necessidade de maior concretização em lei ou regulamento de tal princípio, merecendo destaque a posição de Eckard Rehbinder, o qual salienta que, na prática, o mesmo se aplica em um sentido limitado de que o poluidor suporta apenas os custos do controle da poluição surgidos da regulamentação ambiental, não havendo intenção de internalização completa dos custos. Cabe ressaltar a posição de Maria Alexandra de Sousa Aragão a qual reconhece a ampla aceitação do princípio embora constate que a aplicação do mesmo tem sido incoerente, vaga e, frequentemente, contraditória. ${ }^{44}$

Ademais, afirma Morato Leite que a principal virtude do PPP é precisar que as atividades econômicas são essencialmente poluidoras e que os agentes responsáveis pela poluição devem ser responsabilizados. Deste

\footnotetext{
${ }^{43}$ LEITE, op. cit., p. 60.

${ }^{44}$ Ibid. p. 60 e 61.
} 
modo, o PPP deve ser articulado com outros princípios tal qual o da responsabilização ambiental. ${ }^{45}$

O desiderato do PPP, entretanto, difere do desta última na medida em que o primeiro busca evitar danos ao meio ambiente, ou, pelo menos, diminuí-lo, fazendo isso através da imposição de um custo ambiental àquele que se utiliza dos recursos ambientais em proveito econômico. ${ }^{46}$

Inegável a importância da prevenção e da precaução dos danos ao meio ambiente devendo tais medidas sempre prevalecer sobre as ações de reparação dos bens ambientais tendo em vista que estes dificilmente retornarão ao status quo ante ${ }^{47}$. Todavia, conforme afirma Mirra, "tem-se observado também um certo fracasso no campo preventivo, ou melhor, uma certa limitação ou incapacidade de as medidas estritamente preventivas manterem o equilíbrio ecológico do meio ambiente" ${ }^{48}$.

Expõe o autor, como motivos para tal insucesso, a

certa tolerância da Administração e, por vezes, da própria legislação diante de determinadas agressões ao meio ambiente e, também, em função da negligência e imprudência do homem em exercício de suas atividades, contra as quais, como se sabe, nenhum dispositivo ou mecanismo preventivo pode ser inteiramente eficaz 49 .

Desta forma, conforme lição deste renomado jurista, é necessário admitir que um sistema eficaz de preservação e conservação do meio ambiente supõe a responsabilização dos causadores de danos ambientais da maneira mais ampla possível tanto na esfera penal, quanto na esfera civil e administrativa, podendo ser utilizados os três sistemas cumulativamente devido a independência e a autonomia destes três sistemas de responsabilidade existentes.

Tal independência entre os referidos sistemas decorre do texto constitucional o qual dispõe em seu art. 225, parágrafo $3^{\circ}$ que

\footnotetext{
${ }^{45}$ Ibid. p. 61.

${ }^{46}$ ANTUNES, op. cit., p. 222.

${ }^{47}$ LEUZINGER, Márcia Dieguez. Responsabilidade civil do Estado por danos ao meio ambiente. Revista de Direito Ambiental, São Paulo, n. 45, 2007. p. 187.

${ }^{48}$ MIRRA, Fundamentos..., op. cit., p. 18.

${ }^{49}$ Id. Princípios..., op. cit., p. 62
} 
As condutas e atividades consideradas lesivas ao meio ambiente sujeitarão os infratores, pessoas físicas ou jurídicas, a sanções penais e administrativas, independentemente da obrigação de reparar os danos causados.

No sentido ainda da autonomia entre as responsabilidades, possibilitando a cumulação da responsabilidade civil com a administrativa há também o art. 14, parágrafo $1^{\circ}$, da Lei no $.6938 / 81$.

Conclui-se, deste modo, que pode o poluidor, pela prática de um único ato, ser responsabilizado civil, penal e administrativamente. ${ }^{50}$

Leuzinger defende que, ocorrido um dano ambiental, surge para o agente um dever de repará-lo através da responsabilidade civil extracontratual, não se abdicando, porém, da possibilidade de, pelo mesmo fato, responder ainda o agente penal e administrativamente, suportando as três espécies de sanção. ${ }^{51}$

Segundo a referida autora, a responsabilidade administrativa surge no momento em que há a violação de normas de natureza administrativa, enquanto a responsabilidade penal tem sua origem na infração das normas penais que incluem a conduta do agente dentre o rol de condutas criminosas. Já a responsabilidade civil tem sua origem em um fato que gere prejuízo a terceiros, tendo em vista a violação de um direito que merecerá reparação.

Há que se ressaltar, de acordo com Antonio Herman Benjamin, que as técnicas de proteção ao meio ambiente são (e precisam ser) complementares entre si e devem funcionar de maneira integrada, da responsabilidade civil, penal e administrativa ao planejamento, auditorias e instrumentos econômicos ${ }^{52}$.

No mesmo sentido, afirma Leuzinger "as esferas de responsabilidade, a princípio, são independentes, ou seja, não se comunicam" 53 . Contudo, adverte a autora que a absolvição criminal por

\footnotetext{
${ }^{50}$ Id. Fundamentos..., op. cit., p. 18.

${ }^{51}$ LEUZINGER, op. cit., p. 187.

${ }^{52}$ BENJAMIN, op. cit., p. 10

${ }^{53}$ LEUZINGER, op. cit., p. 187.
} 
ausência de autoria ou materialidade, e, estritamente nestas hipóteses ${ }^{54}$, será causa de afastamento da responsabilidade civil e da administrativa. ${ }^{55}$

É importante notar que no âmbito civil, tendo em vista as peculiaridades do dano ao meio ambiente, as quais o diferenciam do dano comum tornando-o, de certa forma, mais grave, a responsabilidade civil tradicional passou por adaptações visando à responsabilização do poluidor e à reparação do dano.

Conforme ensinamento de Álvaro Mirra ${ }^{56}$, duas regras são de maior importância quando se trata de responsabilidade civil pelo dano ambiental: a da responsabilidade objetiva do degradante e da reparação integral do prejuízo causado.

De acordo com o previsto no artigo $14, \S 1^{\circ}$ da Lei no $.6938 / 81$, "sem obstar a aplicação das penalidades previstas neste artigo, é o poluidor obrigado, independentemente da existência de culpa, a indenizar ou reparar os danos causados ao meio ambiente e a terceiros afetados por sua atividade", caracterizando a responsabilidade do poluidor independentemente da existência de culpa.

Já a reparação integral do prejuízo tem como objetivo propiciar a recomposição do meio ambiente, na medida do possível, no estado em que o mesmo se encontrava antes da ocorrência do dano. Tarefa bastante árdua quando se trata de danos ao meio ambiente, tendo em vista a frequiente impossibilidade de se resgatar as mesmas condições existentes anteriormente. ${ }^{57}$

A título de exemplo, há os casos de extinção de determinadas espécies devido a um dano ambiental. Estas, ainda que se procure fazer com que o meio ambiente retorne ao status quo ante, não voltarão a existir, gerando um rompimento em diversas cadeias alimentares e, consequentemente, um desequilíbrio no macrobem tutelado.

\footnotetext{
${ }^{54}$ Segundo a autora, afora estas hipóteses, será possível a absolvição no juízo penal e a condenação ao pagamento de multa administrativa e à reparação dos danos. (Ibid. p. 187)

${ }^{55}$ Ibid. p. 187.

${ }_{57}^{56}$ MIRRA, Princípios, op. cit., p.63.

${ }^{57}$ Ibid. p.63
} 
Tendo em vista a relevância da responsabilização civil pelo dano ambiental, as peculiaridades existentes quando se trata de tal instrumento e as dificuldades ainda encontradas para a aplicação deste princípio, quais sejam a complexidade da reparação, a dificuldade de valoração do dano e, principalmente, a identificação dos poluidores, torna-se necessário o estudo da mesma de forma a propiciar sua aplicação de forma adequada e eficaz. 


\section{Responsabilidade Civil Ambiental}

Como se sabe, e como explicita Antonio Herman Benjamin ${ }^{58}$, a responsabilidade civil é um instrumento poderoso de intervenção em sociedade. Todavia, no período compreendido entre a década de 70 e 80, época de surgimento e consolidação do Direito Ambiental, a mesma foi objeto de desprezo legislativo e acadêmico, atitude surpreendente tendo em vista que a degradação dos recursos naturais e a poluição, inegavelmente, constituem dano e, onde há dano, deve haver a responsabilidade.

$\mathrm{O}$ referido autor aponta quarto causa para tal rejeição:

a) as funcionais (a tradicional visão da responsabilidade civil como instrumento post factum, destinado à reparação e não à prevenção de danos, b) as técnicas (inadaptabilidade do instituto à complexidade do dano ambiental, exigindo, p.ex., um dano atual, autor e vítima claramente identificados, comportamento culposo e nexo causal estritamente determinado), as éticas (na hipótese de terminar em indenização - sendo impossível a reconstituição do bem lesado - a responsabilidade civil obriga, em última análise, a agregar-se um frio valor monetário à natureza, comercializando-a como tal), e d) as acadêmicas (de um lado, uma tendência monopolista e egoísta da doutrina do Direito Público, enxergando a proteção do meio ambiente como seu domínio exclusivo; de outro, uma timidez injustificável da jusprivatística, abdicando de intervir em tão nuclear hemisfério da danosidade humana). ${ }^{59}$

Contudo, da mesma forma que identifica os motivos da rejeição da responsabilidade civil em casos de dano ambiental, Benjamin localiza as causas para a (re) descoberta de tal instituto ${ }^{60}$ : (a) a transformação do meio ambiente de recurso inesgotável e infinito em recurso crítico e escasso, (b) a percepção de que a intervenção solitária do Estado não protegia de forma satisfatória e suficiente o meio ambiente e (c) ao entendimento de que, ainda que se tomem as medidas de precaução e prevenção, os danos ambientais ocorrerão em qualquer atividade.

Além destas razões, destaca uma maior sensibilidade do direito para com a posição da vítima e o surgimento de novos direitos subjetivos, havendo a necessidade de submissão das condutas anti-ambientais ao controle público (centralizado) e privado (descentralizado).

\footnotetext{
${ }^{58}$ BENJAMIN, op. cit., p. 7 e 8.

${ }^{59}$ Ibid. p. 8

${ }^{60}$ Ibid.p. 8 e 9
} 
Por fim, traz o caráter contraditório das mensagens enviadas pelo ordenamento jurídico ao mercado na medida em que isentava o bolso do poluidor ao afastar a possibilidade de sua responsabilidade civil e, ao mesmo tempo, sancionava o mesmo penal e administrativamente.

Deste modo, mister se fez a transformação da responsabilidade civil tradicional visto ter sido a mesma "projetada para funcionar num cenário com uma ou poucas vítimas, regulando o relacionamento indivíduoindivíduo, salvaguardando as relações homem-homem, de caráter essencialmente patrimonial, e não as relações homem-natureza..." ${ }^{61}$ sendo, portanto, ineficiente quando se trata da tutela do meio ambiente.

Antonio Herman Benjamin ${ }^{62}$ menciona, ainda, quatro ordens de dificuldades que justificam a composição de uma disciplina especial para o dano ambiental.

A primeira delas é a difícil identificação dos sujeitos da relação obrigacional vez que os contornos da "dobradinha autor-vítima" 63, em grande parte das vezes, não aparecem bem definidos.

A segunda é a exigência de caracterização da culpa do degradante em sistemas que ainda a exigem, não sendo o caso brasileiro tendo em vista a adoção da responsabilidade civil objetiva após a promulgação da Lei $\mathrm{n}^{\circ}$. 6.938/81 e da Constituição Federal de 1988.

Como terceira e quarta dificuldades, apresenta a complexidade do nexo causal e o "caráter fluido e esquivo do dano ambiental em si mesmo considerado" 64 .

Observa-se então que, na responsabilidade civil ambiental, diferentemente da responsabilidade civil tradicional, a qual pressupõe a definição de forma clara de uma estrutura quadrangular dano-nexo causalcausador-vítima, não raro os causadores são plúrimos, quando não incertos

\footnotetext{
${ }^{61}$ Ibid p. 8

${ }^{62}$ Ibid. p. 12 e 13

${ }^{63}$ Ibid. p. 12

${ }^{64}$ Ibid. p. 12
} 
e as vítimas, devido às características do próprio dano ambiental, pulverizadas e, por vezes, anônimas.

Pode ocorrer também de o responsável não ter recursos necessários e disponíveis para a que se realize a reparação do dano ou, ainda, considerando a possibilidade de existência de danos futuros, pode ocorrer de, no momento de sua manifestação, o degradante não mais existir.

Por todo o exposto, percebe-se, a ineficácia da responsabilidade civil tradicional quando se trata de dano ambiental. Este, supraindividual por excelência, não poderia, de fato, ser tratado de forma adequada pelo Direito Privado. Ademais, a responsabilidade civil tradicional não possui o condão de influenciar os degradantes potenciais que não se sintam ameaçados por uma ação civil, seja porque o sistema substantivo é falho devido à adoção do regime da responsabilidade civil subjetiva e das dificuldades de prova tanto do dano quanto do nexo causal, seja porque não é um sistema de fácil implementação. ${ }^{65}$

Assim, partindo de uma estrutura clássica e afastando-se dos padrões tradicionais, a responsabilidade civil por danos ambientais se consagra, originando uma transmutação jurídica induzida e desejada que surge com um "modelo próprio de responsabilização do degradador" ${ }^{66}$, mais rigoroso, e mais comprometido com os prejudicados ${ }^{67}$.

Como mecanismos para tal transformação, de acordo com Benjamin, há a

ampliação do rol dos sujeitos responsáveis, adotando-se a solidariedade entre eles e abrindo-se a possibilidade de desconsideração da pessoa jurídica; flexibilização do universo de eventuais vítimas, reconhecendo-se o interesse de sujeitos intermediários; permissivo para o afastamento integral da exigência de culpa; facilitação da prova da causalidade (inclusive com inversão do onus probandi); redefinição do conceito de dano e instituição de formas inovadoras para a sua liquidação; enxugamento das hipóteses de exclusão; modelagem peculiar para os remédios reparatórios. Enfatizando-se à reconstituição do bem lesado; um regime próprio para prescrição e decadência; seguro obrigatório ou mecanismo similar em algumas atividades perigosas; facilitação do acesso à justiça para os prejudicados

\footnotetext{
${ }^{65}$ Ibid. p. 20

${ }^{66}$ Ibid. p. 9

${ }^{67}$ Ibid. p. 10
} 
por danos ambientais; instituição de fundos compensatórios de futuras vítimas; e multa civil, para nomear apenas alguns. ${ }^{68}$

Nas palavras do autor,

a valorização recente da responsabilidade civil no universo da proteção ao meio ambiente não se dá pela transposição automática e integral de sua formulação passada, mas pela constituição sobre bases convencionais, de um modelo jurídico profundamente repensado, com características bastante peculiares e cujo traçado mais preciso só recentemente passou a ser desenhado ${ }^{69}$.

\subsection{Fundamentos legais e Funções da Responsabilidade Civil Ambiental.}

Instituída pelo art. $14, \S 1^{\circ}$ da L. 6938/81, a responsabilidade civil ambiental possui seu fundamento axiológico na Constituição Federal de 1988, incidindo de forma direta sobre as relações privadas e passando, nas palavras de Annelise Monteiro Steigleder, a ter função específica de

servir à reparação do dano ambiental autônomo, protegendo-se a qualidade dos ecossistemas, independentemente de qualquer utilidade humana direta e de regimes de apropriação públicos e privados ${ }^{70}$.

Tal percepção é extraída do fato de os $\S \S 2^{\circ}$ e $3^{\circ}$, do art. 225 da Carta Magna, tratarem da responsabilidade civil ambiental após o reconhecimento do direito em causa, tornando fácil a percepção de que

a responsabilidade civil pelo dano ambiental possui uma função social que ultrapassa as finalidades punitiva, preventiva e reparatória, normalmente atribuídas ao instituto ${ }^{71}$.

De acordo com Benjamin, a responsabilidade civil possui certas funções a serem cumpridas e, no terreno ambiental, apesar dos retoques e das reformas, o instituto mantém suas funções tradicionais atribuindo-lhe, todavia, pesos diferentes ${ }^{72}$.

Deste modo, enumera o autor quatro objetivos da responsabilidade civil, quais sejam a compensação das vítimas, a prevenção de acidentes, a minimização dos custos administrativos do sistema e a retribuição.

68 Ibid. p. 10

69 Ibid. p. 10

${ }^{70}$ STEIGLEDER, op. cit., p. 177

${ }^{71}$ Ibid. p. 177.

${ }^{72}$ BENJAMIN, op. cit., p. 14. 
Historicamente, demonstra o autor que a responsabilidade civil, tanto nos sistemas de civil law como naqueles de common law, possuía como finalidade primária a reparação dos danos sofridos por aquele afetados pelas condutas de outrem. Contudo, lembravam-se ainda outras funções, secundárias, como o estímulo da prevenção a danos futuros e o envio de certa mensagem expiatória.

Assim sendo, quando se trata de proteção ao meio ambiente, o instituto observa suas finalidades mantidas, "mas certamente redesenhadas, passando a prevenção (e, pelas mesmas razões, até o caráter expiatório) a uma posição de relevo, pari passu, com a reparação" 73 .

Deste modo, explicita o autor que, ainda que possuindo como pressuposto um dano causado, pode-se falar, até na responsabilidade civil objetiva, em um efeito difuso da prevenção vez que os sujeitos do ordenamento jurídico tenderão a evitar as situações em que se multipliquem as hipóteses de risco na medida em que a condenação do réu sirva para encorajar outros em situação similar a ele a tomar as cautelas necessárias para que se evitem novos danos ${ }^{74}$.

Steigleder, por sua vez, partilha de entendimento diverso demonstrando que a responsabilidade civil, em sua moldura tradicional, possui como objetivo a reparação dos danos e a punição do responsável não se propondo, "pelo menos em uma aproximação mais ortodoxa, à prevenção de riscos e, tampouco, à redefinição do modus operandi que determinou a produção do dano" 75 . Diverge, portanto, de Benjamin, na medida em que este demonstra a existência de um estímulo à prevenção, ainda que secundário, na responsabilidade civil tradicional.

Todavia, na sociedade pós-industrial, a autora demonstra a necessidade no desempenho de novas funções pela responsabilidade civil, devendo ser instrumento de regulação social prevenindo comportamentos

\footnotetext{
${ }^{73}$ Ibid.. p. 15 .

${ }^{74}$ Ibid. p. 15.

${ }^{75}$ STEIGLEDER, op. cit., p. 178.
} 
anti-sociais - tais quais aqueles que impliquem na geração de riscos -, distribuindo a carga dos riscos e garantindo os direitos dos cidadãos.

Deve tal instrumento ser ainda mecanismo para indenização das vítimas objetivando a superação das desigualdades entre estas e o produtor do dano tendo em vista que a debilidade da relação encontra-se na impotência e na fragilidade daqueles que sofrem o dano ambiental perante as fontes modernas dos danos tecnológicos ${ }^{76}$.

Afirma a autora que, buscando a fundamentação para a responsabilidade civil na Constituição Federal, há um alargamento em suas funções voltando-se o instituto à consecução de valores tais como a dignidade da pessoa humana e o bem social, constitucionalmente protegidos. $^{77}$

Vincula-se ainda o conteúdo da função social da responsabilidade civil, voltada para a proteção do meio ambiente, aos princípios da responsabilidade social e da solidariedade social a partir da superação do individualismo no âmbito das relações econômicas.

Annelise menciona o autor José de Sousa Cunhal Sendin o qual se refere à existência de direitos e interesses os quais "não podem ser sacrificados por terceiros e em face dos quais não é suficiente a existência de um mecanismo de redistribuição de riscos e custos". Expõe ainda que não se objetiva

reconstituir um status quo moral por forma a repor a igualdade (formal) entre lesante e lesado, mas sim garantir a prevalência do interesse público ambiental (protegido de forma específica) face a outros interesses que the são contrapostostos $^{78}$.

Conclui, fazendo referência ainda ao jurista português, que tal perspectiva se forma por normas de ordem pública as quais determinam uma configuração própria à responsabilidade civil de modo que a responsabilidade civil ambiental assenta-se em um sistema pré-determinado

\footnotetext{
${ }^{76}$ Ibid. p. 179.

${ }^{77}$ Ibid. p. 179 .

${ }^{78}$ Ibid. p. 179.
} 
de responsabilidade civil recolhendo contribuições da dogmática de direito privado e público adquirindo assim certa autonomia. ${ }^{79}$

Ressalta Morato Leite que a utilização de tal instituto adaptado ao dano ambiental proporcionará uma abertura na esfera privada, possibilitando a atuação de indivíduos e associações, através do exercício da cidadania, na tutela pelos bens ambientais. ${ }^{80}$

Segundo Benjamin, em termos econômicos, sob a sombra do princípio do poluidor-pagador, "a responsabilidade civil é vista como uma das técnicas de incorporação das chamadas externalidades ambientais ou custos sociais ambientais decorrentes da atividade produtiva" ${ }^{81}$ sendo a forma jurídica mais direta para a viabilização pelo Direito Privado, de tal princípio. Deste modo, demonstra que, diante da insuficiência dos demais mecanismos tais qual a prevenção, sanções penais e administrativas, diz-se que a responsabilidade civil é a última ratio do processo de internalização de forma a corrigir o déficit ambiental.

Infere, portanto, que "a responsabilidade civil nada mais é do que uma técnica de alocação de perdas e danos oriundos das atividades humanas" ${ }^{82}$. Menciona o autor, que no plano do direto há três soluções conhecidas para tal locação. A primeira delas é deixar o dano onde fora processado, respondendo a vítima, e só ela, pelos seus custos. A segunda é repartir o dano entre o autor e a vítima. Por fim, aponta a conversão dos prejuízos em reparação obrigando o degradante a arcar com seus custos como a técnica adotada pelo Direito moderno tendo em vista ser a mesma a única que leva à incorporação das externalidades ambientais.

Benjamin demonstra que a degradação ambiental é uma forma de apropriação, por parte do poluidor, dos direitos pertencentes a terceiros. Deste modo, caso não haja a internalização, "o custo deixa de ser comercial e se transforma em social, tanto quanto evita refletir no preço final dos

\footnotetext{
${ }^{79}$ Ibid. p. 179 e 180.

${ }^{80}$ LEITE, op. cit., p. 66.

${ }^{81}$ BENJAMIN, op. cit., p. 16 e 17.

${ }^{82}$ Ibid. p. 16.
} 
produtos e serviços fornecidos e repercute sobre a comunidade ou sobre alguns de seus setores ${ }^{83}$.

Finalmente, explicita a cooperação da responsabilidade civil ambiental para com o princípio da precaução, na medida em que, através da obrigação ao poluidor de incorporar nos seus custos o preço da degradação que causa, estimula as atividades que de modo mais eficiente reduzem seus riscos ambientais, diminuindo os acidentes contra o meio ambiente. ${ }^{84}$

Neste sentido, dispõe Morato Leite ${ }^{85}$ quando menciona o autor José de Souza Cunhal Sendim, o qual destaca que os eventuais poluidores, tomando ciência de que serão economicamente responsáveis pelo dano ambiental, possuem motivo suficiente para evitar e prevenir a ocorrência dos mesmos. Consequentemente, há a promoção da redução dos riscos ambientais na medida em que a responsabilidade Civil passa a fazer com que o poluidor atue ex ante à degradação ambiental.

Quanto à existência do risco, Steigleder afirma que a introdução de externalidades ambientais negativas na sociedade gera a responsabilidade social pelo simples perigo ao qual se expõe a mesma, devendo as fontes geradoras das situações de risco, suprimir o fator de risco do contexto social. O que se requer é, apenas, a mera exposição da sociedade ao risco e não a concretização do dano. ${ }^{86}$

Isto é reforçado, ainda, pela adoção da teoria do risco da atividade segundo a qual persiste a obrigação de reparação dos danos causados independentemente de culpa ou de dolo desde que a atividade gere riscos. De acordo com Steigleder, tal assunção de risco possui fundamentação dúplice: a) a situação objetiva do dano causado que deve ser prevenido e reparado e b) a situação subjetiva do agente causador que não se limita apenas à culpa ou dolo do mesmo, mas estende-se ao fato de ser o mesmo i.) guardião ou dono da coisa perigosa, ii.) titular dos benefícios gerados

\footnotetext{
${ }^{83}$ Ibid. p. 17.

${ }^{84}$ Ibid. p. 17.

${ }^{85}$ LEITE, op. cit., p. 65 e 66.

${ }^{86}$ STEIGLEDER, op. cit., p. 180.
} 
pela atividade lesiva, iii.) estar em melhores condições para suportar o dano fortuitamente causado ou iv) haver-se enriquecido com o dano alheio. ${ }^{87}$

A referida autora afirma ainda que

o aprofundamento dessa noção de dever de garantia, ou de incolumidade, perante o meio ambiente, gerando a obrigação de internalizar os riscos inerentes à atividade, antes da ocorrência de danos, passa pela compreensão dos princípios do direito ambiental que dialogam com a responsabilidade civil e atuam nas suas funções. ${ }^{88}$

Tais princípios, aos quais a autora se refere, são os princípios da precaução e da prevenção e do poluidor-pagador, já estudados no tópico anterior e ao princípio da solidariedade com o futuro. De acordo com este e tendo em vista o sentido do art. 225, caput, da Constituição Federal, a responsabilidade civil acaba por ampliar sua função, devendo responder de forma satisfatória às necessidades de reparação dos danos ambientais a fim de que possam as gerações futuras usufruir, pelo menos, das mesmas condições que possuímos na atualidade. ${ }^{89}$

Já Benjamin ${ }^{90}$ aponta como base princípiológica da responsabilidade civil ambiental os princípios da precaução e do poluidor-pagador, já expostos anteriormente e os princípios do usuário-pagador e da reparação integral.

O princípio do usuário-pagador, segundo o autor, "partindo do princípio do poluidor pagador, estabelece que os preços devem refletir todos os custos sociais do uso e esgotamento do recurso", ${ }^{\text {. }}$. Defende o jurista que diferentemente do sistema tradicional, em que a regra é o esgotamento de determinado recurso comum não acarretar a compensação à coletividade que dele é titular, deve haver o pagamento do usuário pelo consumo do bem que é de todos, incorporando assim tal custo no preço final do produto. Isto ocorre, conforme demonstra, devido ao fato de o recurso ambiental possuir titularidade difusa e, portanto, sua apropriação e

\footnotetext{
${ }^{87}$ Ibid. p. 182.

${ }^{88}$ Ibid. p. 183.

${ }^{89}$ Ibid. p. 183.

${ }^{90}$ BENJAMIN, op. cit., p. 17.

${ }^{91}$ Ibid. p. 19.
} 
utilização por uns poucos, sem qualquer compensação, acarretar no "pagamento da conta" pelo público em geral. Não bastando o exposto, a coletividade, além de não ser compensada pela utilização do bem, ainda acaba por suportar as despesas com medidas para protegê-lo, evitando a perda de um recurso originariamente seu. ${ }^{92}$

De acordo com o princípio da reparabilidade integral do dano ambiental, brevemente exposto quando se tratou do princípio da responsabilização, veda-se toda e qualquer forma de modificação ou limitação da reparação ambiental devendo a mesma ser sempre integral de modo a assegurar a proteção ao meio ambiente ecologicamente equilibrado. 93

\subsection{Pressupostos da Responsabilidade Ambiental}

Conforme dispõe Steigleder ${ }^{94}$, o art. $14, \S 1^{\text {o }}$, da Lei $n^{\circ} .6938 / 81^{95}$, prevê que, tratando-se de danos ambientais, é o poluidor obrigado a indenizar ou reparar os danos causados ao meio ambiente e a terceiros, afetados por sua atividade, independentemente da existência de culpa, optando assim pela adoção do regime da responsabilidade civil objetiva, escolha esta recepcionada pelos $\S \S 2^{\circ}$ e $3^{\circ}$ do art. 225 da Constituição Federal de $1988 .{ }^{96}$

Benjamin $^{97}$ nos ensina que a objetivação da responsabilidade civil no campo ambiental é uma tendência mundial que, a seu ver, é irreversível, tendo em vista a sua adoção pela Convenção de Lugano, do Conselho da Europa. Contudo, ressalva o autor que se enganam aqueles que acreditam

\footnotetext{
${ }^{92}$ Ibid. p. 18 e 19.

${ }^{93}$ Ibid. p. 19.

94 STEIGLEDER, op. cit., p. 195.

$95 \S 1^{\circ}$ - Sem obstar a aplicação das penalidades previstas neste artigo, é o poluidor obrigado, independentemente da existência de culpa, a indenizar ou reparar os danos causados ao meio ambiente e a terceiros, afetados por sua atividade. O Ministério Público da União e dos Estados terá legitimidade para propor ação de responsabilidade civil e criminal, por danos causados ao meio ambiente.

96 Para o estudo da evolução da responsabilidade civil subjetiva para a responsabilidade civil objetiva, ver CAVALIERI FILHO, Sergio. Programa de Responsabilidade Civil. $7^{\text {a }}$ ed. São Paulo: Atlas, 2007. p.127 e 128.

${ }^{97}$ BENJAMIN, op. cit., p. 39.
} 
que a instituição de tal regime tenha eliminado todos os males da responsabilidade civil ambiental, realizando a transposição de todas as barreiras que separam a reparação do dano da vítima. As dificuldades inerentes ao estabelecimento do nexo causal e da comprovação do dano permanecem. Além disto, não se pode olvidar que, ainda no regime da responsabilidade objetiva, dependendo da teoria que se adote, há a previsão de causas de exclusão da responsabilidade, tal qual previsto em lei, devolvendo o prejudicado à estaca zero. ${ }^{98}$

Como pressupostos para a responsabilização do poluidor, Steigleder indica a) "a existência de uma atividade que implique riscos para a saúde e para o meio ambiente, impondo-se ao empreendedor a obrigação de prevenir tais riscos (princípio da prevenção) e de internaliza-los em seu processo produtivo (princípio do poluidor-pagador)”, b) o risco de dano ou dano e c) o nexo de causalidade entre a atividade e o resultado potencial ou efetivo. ${ }^{99}$

Tal sistema assemelha-se ao da responsabilidade objetiva aplicado na responsabilidade civil tradicional, segundo a qual, de acordo com Cavalieri Filho ${ }^{100}$, haverá uma conduta ilícita, um dano e o nexo causal.

Todavia, devido às características e à importância do bem jurídico tutelado, no caso da responsabilidade civil objetiva pelo dano ambiental, não há que se indagar a ilicitude da conduta e, tampouco, tal qual demonstra Sérgio Cavalieri Filho ${ }^{101}$, a existência ou não da culpa (lato sensu) ${ }^{102}$, as quais serão irrelevantes para a configuração do dever de indenizar.

\footnotetext{
${ }^{98}$ Ibid. p. 40.

99 STEIGLEDER, op. cit., p. 196.

${ }^{100}$ CAVALIERI FILHO, Sergio. Programa de Responsabilidade Civil. $7^{\mathrm{a}}$ ed. São Paulo: Atlas, 2007. p. 126

${ }^{101}$ Ibid. p. 126

${ }^{102}$ De acordo com Sergio Cavalieri Filho, a culpa, em seu sentido amplo, abrange toda espécie de comportamento contrario ao direito, seja ela intencional, configurando-se, neste, caso, o dolo, ou não intencional, no caso da culpa. Demonstra ainda o referido autor que, para alguns, não há utlidade prática na distinção entre ambos tendo em vista que na responsabilidade civil subjetiva, o que se procura é a reparação dos danos sofridos pela lesão atraves da indenização e não a punição ou sanção da conduta, como no caso da responsabilidade penal na qual o grau de culpa do agente influencia na cominação da pena. (CAVALIERI FILHO, op. cit., p.29 e 30).
} 
Simplificando os pressupostos existentes, a doutrina, em sua grande maioria $^{103}$, menciona a existência de dois, os quais suficientes para à configuração da responsabilidade pelos danos causados ao meio ambiente: o dano e o nexo de causalidade.

Isto ocorre tendo em vista a adoção da teoria do risco quando se trata de responsabilidade civil ambiental, conforme estudo realizado mais adiante, a qual afasta a necessidade de análise da culpabilidade existente na conduta e, ainda, do exame quanto à licitude ou não da mesma. Assim, difere da responsabilidade civil tradicional, na medida em que nesta, tendo em vista a adoção da teoria da culpa, se afere a conduta do agente para que se verifique a existência de dolo, negligência, imprudência ou imperícia.

Importa ter em mente que a questão em torno do dano ambiental é a existência de prejuízos realizados por poucos em detrimento de interesses majoritários da sociedade independentemente da intenção ou culpa do agente. Não é razoável, neste caso, a aferição da existência da culpabilidade na realização da conduta pelo agente tendo em vista a existência de uma situação de injustiça para com a maioria que acaba por suportar os prejuízos decorrentes da obtenção de lucros por alguns poucos de através do exercício de atividades de risco.

Benjamin demonstra que o dano ambiental geralmente é produzido por atos totalmente legítimos, ajustados a disposições regulamentares e que, ainda assim, produzem variação no meio ambiente desestabilizando o equilíbrio ecológico constitucionalmente protegido. Nestes casos, o prejuízo não é resultado almejado ou esperado pelo agente que apenas busca, observando e cumprindo as normas e padrões legalmente estabelecidos, o exercício de atividades, por vezes, bastante úteis à sociedade. O que se percebe nestas hipóteses é o caráter inevitável e, por vezes, imprevisível, de certos danos ambientais na medida em que os padrões estabelecidos e

\footnotetext{
103 Neste sentido, Adalberto Pasqualloto (PASQUALOTTO, Adalberto. Responsabilidade Civil por Dano Ambiental: Considerações de ordem material e processual. In BENJAMIN, Antonio Herman (coord.). Dano ambiental: prevenção, reparação e repressão. São Paulo: Editora Revista dos Tribunais, 1993. p. 453), Márcia Dieguez Leuzinger (LEUZINGER, op. cit,. p. 189).
} 
cumpridos, não tenham sido suficientes para não ocorrência do mesmo. ${ }^{104}$ Em grande parte das vezes, é isto o que ocorre. As condutas, ainda que legítimas e legais, acabam por produzir danos ao meio ambiente e, caso se considerasse a culpabilidade para o exercício da reparação, muitos danos ambientais restariam irreparáveis.

Devido a este fato, de acordo com Steigleder ${ }^{105}$, o ordenamento jurídico passa a supor que aqueles que se entregam a atividades gravadas pelo regime da responsabilidade objetiva, devem fazer um juízo de previsão aceitando, com isso, as consequiências danosas inerentes às mesmas e incorporando as externalidades ambientais negativas.

Deste modo, toda atividade que implique riscos para a saúde ou para o meio ambiente, torna seu autor responsável pelo dano que causar, ainda que a conduta seja lícita e/ ou que não exista culpa por sua parte. Isto decorre, como ensina a autora ${ }^{106}$, da posição de garantidor da preservação ambiental em que se coloca todo aquele que explore atividades econômicas, não se investigando a ação do poluidor tendo em vista que o risco a ela se substitui.

\subsubsection{O Dano Ambiental}

Como pressuposto para a responsabilização civil dos degradantes, temos, primeiramente, a existência de um dano ambiental. Conforme leciona Benjamin, a reparação só é devida quando existe um dano ambiental e, ainda assim, nem todo dano será indenizável. Imprescindível, portanto, é a definição do que venha a ser um dano ambiental. ${ }^{107}$

Krell leciona que, no sistema jurídico nacional, é possível a identificação de uma bifurcação no que tange ao dano ambiental: "num lado, o dano público contra o meio ambiente, que é 'bem de uso comum do povo' (Art.225 CF), de natureza difusa, atingindo um número indefinido de

\footnotetext{
${ }^{104}$ BENJAMIN, op. cit., p. 40.

${ }^{105}$ STEIGLEDER,op. cit., p. 196.

${ }^{106}$ Ibid. p. 196.

${ }^{107}$ BENJAMIN,op. cit., p. 46.
} 
pessoas, sempre devendo ser cobrado por Ação Civil Pública ou Ação Popular e sendo a indenização destinada a um fundo; no outro lado, o dano ambiental privado, que dá ensejo à indenização dirigida à recomposição do patrimônio individual das vítimas”. 108

Neste sentido, leciona Leuzinger, demonstrando que o dano ambiental pode recair tanto sobre o "patrimônio ambiental, comum à coletividade, causando, assim, um dano ambiental coletivo", como também, sobre as pessoas ou bens, gerando um dano ambiental individual que legitima os lesados à reparação pelos prejuízos morais ou patrimoniais. ${ }^{109}$

De acordo com Steigleder, o conteúdo ambivalente do dano ambiental, tendo em vista o ordenamento jurídico no qual está presente, é utilizado de modo a designar as alterações nocivas bem como os efeitos que tais alterações podem provocar na saúde dos indivíduos e em seus interesses. Deste modo, a expressão dano ambiental tem o condão de designar um dano em ricochete aos interesses legítimos de determinada pessoa, se individualmente considerada, configurando um dano particular, como também designará um dano que recaia sobre o patrimônio ambiental, bem cuja titularidade pertence à coletividade. ${ }^{110}$

Como bem lembra Benjamin ${ }^{111}$, o dano ambiental pessoal pode se mostrar como prejuízo individual, coletivo stricto sensu, difuso e individual homogêneo. Como, por exemplo, em casos em que uma atividade poluidora acabe causando danos à massa difusa de indivíduos de determinada região, ao meio ambiente do trabalho e aos indivíduos particularizados, demonstrando-se assim que para uma ação há a possibilidade de diversas modalidades de danos ensejando diverso dever de reparação.

Steigleder observa que o conceito de dano ambiental poderá ser mais ou menos amplo de acordo com interesses preferencialmente tutelados em certas sociedades. Assim, sob a ótica do paradigma antropocêntrico-

\footnotetext{
108 KRELL, Andréas Joachim. Concretização do dano ambiental: objeções à teoria do risco integral. Revista de Informação Legislativa, Brasília, v. 139, 1998. p.22-37.

${ }^{109}$ LEUZINGER, op. cit., p. 189.

110 STEIGLEDER, op. cit., p. 117.

111 BENJAMIN, op. cit., p. 50.
} 
utilitarista, tal qual na Alemanha e Espanha, apenas será reparável o dano que afete indivíduos identificáveis e/ou seu patrimônio. Por outro lado, em ordenamentos que reconhecem o meio ambiente como um bem jurídico tutelado, do conceito de dano ambiental será mais amplo, englobando tanto as lesões patrimoniais quanto extrapatrimoniais ao bem ambiental.

Contudo, para que se perceba a justificação axiológica do dano ambiental, há que se realizarem considerações acerca de seu objeto.

A Constituição Federal, em seu art. 225, caput, refere-se ao bem jurídico ambiental como um macrobem, imaterial, indisponível, cuja titularidade é difusa, sendo, portanto, um bem jurídico autônomo. Deste modo, ocorrerá um dano ambiental jurídico quando houver lesão ao bem de uso comum do povo, autônomo em relação aos danos de bens particulares. Reconhece-se, portanto, a existência de danos ao meio ambiente em si mesmo considerado, denominado por Sendim de "dano ecológico puro" ${ }^{113}$, independente das suas repercussões nas pessoas e em seus bens, superandose, portanto, a concepção antropocêntrica-utilitarista. ${ }^{114}$

Do mesmo entendimento, partilha Canotilho, para quem há os danos ambientais, os quais consistem em danos a bens jurídicos concretos e os danos ecológicos, consistentes nas lesões internas ao sistema ecológico natural independente da violação de interesses particulares e individuais. ${ }^{115}$

Assim, partindo-se de um conceito amplo e unitário de meio ambiente, há que se ressaltar que o dano ambiental engloba também as lesões ao patrimônio histórico-cultural, sendo o mesmo autônomo em relação às lesões produzidas a terceiros face à mesma degradação ambiental.

Deste modo,

\footnotetext{
${ }^{112}$ STEIGLEDER, op. cit., p. 117 a 120.

${ }^{113}$ Steigleder ressalva que, na definição de Sendim sobre "dano ecológico puro", não se englobam os bens culturais, tendo em vista que para o autor, tais bens diferem-se substancialmente dos bens considerados parte do conceito amplo de meio ambiente. Alem disto, a ratio quanto à sua proteção, bem como seu objeto, também não é a mesma. (STEIGLEDER, op. cit., p. 121) 114 Ibid. p. 120.

115CANOTILHO, J. J. Gomes. A responsabilidade por danos ambientais: aproximação juspublicística. In AMARAL, Diogo de Freitas do (coord.). Direito do Ambiente. Oeiras: Instituto de Administração, 1994. p.402.
} 
os danos ambientais lato sensu resultam sempre sobrepostos aos danos ecológico puros e também aos danos individuais, pois, nas duas hipóteses, estará sendo lesado o interesse difuso adjacente, relativo à manutenção da sadia qualidade de vida. ${ }^{116}$

Edis Milaré distingue o dano ambiental público do dano aos bens privados decorrentes da degradação. ${ }^{117}$ Todavia, ressalta que a menção ao caráter público não tem em vista a titularidade sobre o bem, mas o fato de que se trata de lesão ao interesse público, de natureza difusa, na medida em que são afetados os bens de uso comum do povo. Além disto, o estado não possui legitimidade exclusiva na tutela do meio ambiente.

Por meio da Ação Civil Pública (art. $1^{\circ}$ da L. 7347/85), estão legitimados a) a União, b) os Estados, c) Municípios, d) empresas públicas, e) fundações, f) autarquias, g) sociedades de economias mista ou associações, constituídas há, no mínimo, um ano e desde que incluídas dentre suas finalidades, a proteção ao meio ambiente ou ao patrimônio artístico, estético, histórico, paisagístico e turístico, de acordo com o art. $5^{\circ}$ do referido diploma legal, bem como h) o Ministério Publico, cuja legitimidade infere-se do disposto no art. $14, \S 1^{\circ}$ da Lei $n^{\circ}$. 6938/81. ${ }^{118}$ Além destes, legitimados também serão os cidadãos que, por intermédio da ação popular, prevista no art. $5^{\circ}$, inciso LXXIII da Constituição Federal e disciplinada pela Lei $\mathrm{n}^{\circ}$. 4717/65, podem desconstituir atos lesivos ao patrimônio ambiental.

Para Costa Neto ${ }^{119}$, o dano ambiental, para que enseje a responsabilização do agente, pressupõe a ofensa a um interesse juridicamente tutelado tal qual o bem jurídico meio ambiente, constitucionalmente protegido. Cita, o referido autor, José de Sousa Cunhal Sendin para quem, o dano ambiental será "a perturbação do estado do

\footnotetext{
${ }^{116}$ STEIGLEDER, ob. cit., p. 122.

${ }^{117}$ MILARÉ, Edis. Direito do Ambiente. $5^{a}$ edição ref., atual. e ampl. São Paulo: Revista dos Tribunais, 2007. p. 809 a 814.

${ }^{118}$ STEIGLEDER, ob. cit., p. 125.

119 COSTA NETO, Nicolao Dino de Castro e. Proteção Jurídica do meio ambiente. I-Florestas. Belo Horizonte: Del Rey, 2003. p. 261 a 264.
} 
ambiente determinado pelo sistema jurídico ambiental" ${ }^{120}$. Contudo, ressalva Costa Neto que, caso levada ao extremo, tal concepção resultaria no entendimento de que qualquer intervenção humana ou alteração no meio ambiente sujeitaria o agente à responsabilização. Nestes termos, até uma mera poda de árvores, autorizada por leis, ensejaria responsabilização, não sendo, portanto, razoável. Logo, não poderá ser qualquer perturbação capaz de acarretar a responsabilização civil pelo dano ambiental, mas apenas aquelas que expressem um sentido de anormalidade de modo a desequilibrar o sistema. Além disto, dispõe que tal anormalidade deverá ter sido causada pela desobediência aos limites suportados pelo sistema ecológico, abalando assim sua funcionalidade. Alguns parâmetros destes limites são estabelecidos pela legislação brasileira tais qual a definição legal de poluição contida no artigo $3^{\circ}$, inciso III da Lei $n^{\circ}$. 6938/81:

Art $3^{\circ}$ - Para os fins previstos nesta Lei, entende-se por:

III - poluição, a degradação da qualidade ambiental resultante de atividades que direta ou indiretamente: a) prejudiquem a saúde, a segurança e o bem-estar da população; b) criem condições adversas às atividades sociais e econômicas; c) afetem desfavoravelmente a biota; d) afetem as condições estéticas ou sanitárias do meio ambiente; e) lancem matérias ou energia em desacordo com os padrões ambientais estabelecidos;

Steigleder ${ }^{121}$, difere ainda a poluição, prevista no artigo $3^{\circ}$, inciso III da Lei $\mathrm{n}^{\circ}$. 6938/81, do dano ambiental na medida em o artigo $3^{\circ}$, inciso II do referido diploma legal estabelece que

Art $3^{\circ}$ - Para os fins previstos nesta Lei, entende-se por:

II - degradação da qualidade ambiental, a alteração adversa das características do meio ambiente.

Para Benjamin, de forma genérica, dano ambiental será "a alteração, deterioração ou destruição, parcial ou total, de quaisquer dos recursos naturais, afetando adversamente o homem e/ou a natureza", abrangendo

\footnotetext{
${ }^{120}$ SENDIM, José de Souza Cunhal. Responsabilidade Civil por Danos Ecológicos: da reparação do dano através de restauração natural. Coimbra: Coimbra Editora, 1998. p. 129. apud COSTA NETO, Proteção..., ob. cit., p. 262.

${ }^{121}$ STEIGLEDER, ob. cit., p. 121.
} 
assim a degradação da qualidade ambiental e a poluição prevista no art. $3^{\circ}$, inciso III da Lei $n^{\circ}$. 6938/81. ${ }^{122}$

De acordo com Krell, é possível se afirmar que onde existir poluição, na maioria das vezes, haverá um dano ambiental de acordo com o art. $1^{\circ}$, inciso I, da Lei n". 7347/85 tendo em vista que "a definição do conceito de dano da lei processual se rege pelas normas do direito ambiental material". Portanto, nem toda alteração negativa do meio ambiente poderá ser qualificada como poluição ou dano, não sendo possível a sua reparação. ${ }^{123}$

No mesmo sentido, leciona Steigleder ${ }^{124}$, para quem nem toda alteração no meio ambiente será reparável tendo em vista que, se assim fosse, negar-se-ía a possibilidade de mudanças e inovações entendendo-se que o estado adequado ao meio ambiente seria o imobilismo.

De acordo com Benjamin ${ }^{125}$, a noção de alteração adversa é bastante complexa vez que nem sempre o que é melhoramento na perspectiva de uns possuirá o mesmo valor para o ecossistema.

Lyra defende que a expressão alteração adversa do meio ambiente corresponde à ruptura do equilíbrio existente no meio ambiente, constitucionalmente protegido. ${ }^{126}$

Assim, de acordo com a doutrina, conforme afirma Steigleder ${ }^{127}$ e $\mathrm{Krell}^{128}$, para que uma alteração seja considerada dano passível de responsabilização mister se faz a presença de três características:

a sua anormalidade que existe onde houver modificação das propriedades físicas e químicas dos elementos naturais de tal grandeza que estes percam, parcial ou totalmente, a sua propriedade ao uso; a sua periodicidade, não bastando a eventual emissão poluidora e a sua gravidade, devendo ocorrer transposições daquele limite máximo de absorção de agressões que possuem os seres humanos e os elementos naturais. ${ }^{129}$

\footnotetext{
122 BENJAMIN, ob. cit., p. 48.

123 KRELL, ob. cit., p.22-37.

${ }^{124}$ STEIGLEDER, ob. cit., p. 129.

125 BENJAMIN, ob. cit., p. 49.

${ }^{126}$ LYRA, Marcos Mendes. Dano Ambiental. Revista de Direito Ambiental, São Paulo, n. 8, 1997. p. 53 .

${ }^{127}$ STEIGLEDER, ob. cit., p. 130.

${ }^{128}$ KRELL, ob. cit., p.22-37.

${ }^{129}$ Ibid. p. 22-37.
} 
Conforme bem lembra Benjamin ${ }^{130}$, diante da complexidade existente quando se trata de dano ambiental, nem sempre será possível que se realize a distinção entre dano direto, conseqüência imediata de uma ação ou omissão, e dano indireto, conseqüência de circunstancias que agravam o dano direto. Logo, diferentemente do regime comum, em que o dano indireto não enseja o dever de reparação, no caso de dano ambiental, ainda que o dano seja indireto, não se eximirá o poluidor do dever de repará-lo.

Além disto, demonstra também que o dano ao meio ambiente evolve não apenas os elementos patrimoniais, mas também os elementos extrapatrimoniais, cabendo-se considerar o dano ecológico moral, previsto pelo ordenamento jurídico pátrio.

\subsubsection{Nexo de Causalidade}

Indispensável, será a existência do nexo de causalidade, o qual é considerado por Steigleder como fator aglutinante que permite a integração do risco na unidade do ato-fonte da obrigação de indenizar. Afirma ainda ser o mesmo um elemento objetivo na medida em que alude a um vínculo externo entre o fato e o dano causado. ${ }^{131}$

Cavalieri Filho ressalta que, a rigor, a questão da causalidade deve será primeira a ser enfrentada na solução de qualquer caso que diga respeito à responsabilidade civil. Adverte, todavia, que tal questão não é simples vez que envolve diversas perplexidades. Observa ainda que o conceito de nexo causal não é jurídico, mas decorre das leis naturais, sendo considerado o vínculo de ligação entre a conduta e o resultado de modo a possibilitar a conclusão de quem foi o causador do dano. ${ }^{132}$

Neste pressuposto, de acordo com a autora, concentra-se um dos maiores problemas quando se trata da responsabilidade civil ambiental tendo em vista a possibilidade de um dano se originar de diversas causas

\footnotetext{
${ }^{130}$ BENJAMIN, ob. cit., p. 50.

${ }^{131}$ STEIGLEDER, ob. cit., p. 196.

${ }^{132}$ CAVALIERI FILHO, ob. cit., p.45 e 46.
} 
concorrentes, sucessivas e simultâneas. ${ }^{133}$ Não é outro, a propósito, o entendimento de Benjamin, dispondo ainda que a prova do nexo causal é complicada e, por vezes, impossível, sendo obstáculo intransponível à reparação das vítimas. ${ }^{134}$

Menciona o autor que dificilmente o dano ambiental possui uma fonte linear sendo desafiador relacionar o efeito a sua causa na maioria dos problemas ambientais. Demonstra ainda a existência de unanimidade na doutrina em reconhecer a natureza complexa e os efeitos difusos da poluição causando danos distanciados, tanto no tempo quando no espaço, das fontes poluentes. ${ }^{135}$

Denomina tal processo de "império da dispersão do nexo causal" 136 , demonstrando que o dano pode ser atribuído a um multiplicidade de agentes, comportamentos e fontes, bem como por fontes que se, por si só, não gerariam tal dano, em conjunto com outras fontes, acaba por ocasionar danos imensuráveis. Deste modo, demonstra o fenômeno da causalidade complexa, decorrente da interação entre o mal funcionamento tecnológico ou técnico, de procedimentos de segurança inadequados ou de erro humano. 137

Porém, há que se ressalvar que, nem sempre, os danos decorrem da inadequação dos procedimentos de segurança adotados ou de erros humanos. Não deixa de ser freqüente a ocorrência de danos ainda que as medidas de cautela e de prevenção tenham sido tomadas, bem como, as normas, limites ou padrões estabelecidos, tenham sido obedecidos. Não rara é a evolução dos meios tecnológicos disponíveis para a mensuração das conseqüências do despejo de determinada substancia no meio ambiente, demonstrando serem inadequados padrões anteriormente estabelecidos. Pode ocorrer ainda de a emissão de determinada substância sozinha, não produzir nenhuma alteração significante no meio ambiente, contudo, a sua interação

\footnotetext{
${ }^{133}$ STEIGLEDER, ob. cit., p. 197.

${ }^{134}$ BENJAMIN, ob. cit., p. 44.

${ }^{135}$ Ibid. p. 44

${ }^{136}$ Ibid. p. 44

${ }^{137}$ Ibid. p. 44.
} 
com outras substancias que, se isoladas também não produziriam alterações no meio ambiente, gera uma reação em cadeia, produzindo graves danos ao meio ambiente.

Benjamin observa dois problemas quanto ao nexo de causalidade ${ }^{138}$. O primeiro deles é a dificuldade em se determinar entre as diferentes possíveis fontes de poluição de uma mesma substância, qual delas efetivamente causou o dano ambiental. Neste caso, a grande dificuldade está na comprovação da relação causal fonte-dano a qual se torna ainda mais dificultosa quando se percebe que muitas das substâncias não são sequer perceptíveis pelos sentidos. Além disto, a possibilidade da existência de longo período de latência e o caráter inconstante e sorrateiro da exposição também contribuem para que a identificação dos autores seja árdua assim como a afirmação quanto a localidade e ao tempo da ocorrência do ato nem sempre é possível.

O segundo problema é a questão da determinação dos males que a vítima apresenta ou da origem do dano ambiental. Isto ocorre por, raramente, existir apenas uma única causa para determinada doença, dificultando-se a pretensão de se identificar se é aquela a substancia (ou atividade particular), previamente identificada, que causou, efetivamente, o dano. Trata-se da "verificação do 'nexo causal entre substância perigosa ou tóxica e o dano' (= identificação da modus operandi da causação do dano pela conduta do agente)". 139

Salienta o autor que o Direito brasileiro não admite qualquer distinção entre a causa principal, a concausa ${ }^{140}$ e a causa acessória, principalmente após a Constituição Federal de 1988, exceto no que diz respeito ao plano do regresso, demonstrando que, seja qual for a contribuição de alguém para a ocorrência de um dano ambiental, o agente

\footnotetext{
138 Ibid. p. 45

${ }^{139}$ Ibid. p. 45.

${ }^{140}$ De acordo com Cavalieri, concausa será outra causa que, juntando-se à principal, concorre para o resultado embora não possua a virtude de excluir o nexo causal desencadeado pela conduta principal e tampo, possui a capacidade de, sozinha, produzir o dano. (CAVALIERI FILHO,op. cit., p 58).
} 
deverá responder pela totalidade do dano ainda que não tenha sido a única causa do mesmo. ${ }^{141}$

Conforme demonstrado anteriormente, o risco de determinada atividade acaba por substituir a investigação da conduta do agente poluidor tendo em vista o fato de que, a partir do momento em que determinada atividade é exercida, gerando benefícios para determinados indivíduos, o seu explorador torna-se garantidor da preservação do meio ambiente. Conseqüentemente, os danos que digam respeito à atividade, serão considerados vinculados à mesma.

Conforme leciona Cavalieri Filho, na busca por um fundamento para a responsabilidade subjetiva, os juristas, principalmente franceses, no final do século XIX, conceberam a teoria do risco. De acordo com esta, risco é perigo e probabilidade significa dano. Deste modo, todo aquele "que exerce atividade perigosa deve-lhe assumir os riscos e reparar o dano dela decorrente" ${ }^{142}$. Conclui então resumindo a teoria do risco:

todo prejuízo deve ser atribuído ao seu autor e reparado por quem o causou, independentemente de ter ou não agido com culpa. Resolve-se o problema na relação de causalidade, dispensável qualquer juízo de valor sobre a culpa do responsável, que é aquele que materialmente causou o dano. ${ }^{143}$

Steigleder demonstra ${ }^{144}$ que a possibilidade de assunção dos riscos pelo agente executor de determinada atividade vem sendo alvo de diversas discussões, gerando o debate acerca de suas duas teorias principais ${ }^{145}$ :

\footnotetext{
${ }^{141}$ BENJAMIN,op. cit.,. p. 45.

${ }^{142}$ CAVALIERI FILHO, ob. cit., p. 128.

${ }^{143}$ Ibid. p. 128.

${ }^{144}$ STEIGLEDER, op. cit., p. 197.

${ }^{145}$ Cavalieri Filho afirma que em torno da idéia central do risco, surgiram diversas subespecies ou modalidades. Destacam-se, entre elas, além das teorias do risco integral e do risco criado, tratadas neste capítulo, as teorias do risco-proveito, do risco profissional e a do risco excepcional. De acorco com a teoria do risco-proveito, responsável será aquele que tira proveito da atividade danosa de modo que o encargo deva incidir onde está o ganho, proveito ou vantagem. A grande dificuldade se encontra na conceituação de proveito. Haverá a necessidade de o mesmo ser econômico? Neste caso, não seria aplicavel quando a degradação tenha se originado de fontes que não visam ganhos. Além disto, à vítima caberia a prova quanto a obtenção de tal proveito, retornando ao complexo problema relacionado à prova. Outra teoria apontada, é a teoria do risco profissional a qual sustenta que o dever de indenizar terá lugar sempre que o fato prejudicial seja decorrente de atividade ou profissão do lesado. Já a teoria do risco excepcional, defende que a reparação será devida sempre que o dano for consequencia de um rico excepcional, o qual escapa da atividade comum da vítima, ainda que estranho ao trabalho de normalmente exerça. A teoria do risco, conforme demonstra, tem sido alvo de duras criticas, sob o argumentod e que em virtude da
} 
De um lado, a teoria do risco integral, mediante a qual todo e qualquer risco conexo ao empreendimento deverá ser integralmente internalizado pelo processo produtivo, devendo o responsável reparar quaisquer danos que tenham conexão com sua atividade; e, de outro, a teoria do risco criado, a qual procura vislumbrar, dentre todos os fatores de risco, apenas aquele que, por apresentar periculosidade, é efetivamente apto a gerar as situações lesivas, para fins de imposição de responsabilidade". ${ }^{146}$

A teoria do risco integral originalmente legitimou a responsabilidade civil objetiva na medida em que prevê a reparação do dano ainda que involuntário e responsabiliza o agente por todo ato causador do mesmo, excetuando-se apenas os fatos exteriores ao homem. Tal posicionamento não admite as excludentes de responsabilidade, quais sejam a força maior, a ação de terceiros ou da vítima e o caso fortuito. ${ }^{147}$

Segundo Benjamin ${ }^{148}$, esta é a teoria adotada pelo Direito Ambiental brasileiro na medida em que abriga a teoria da responsabilidade civil objetiva a qual implica que a pessoa que cria o risco deve reparar os danos advindos de seu empreendimento bastando, para tanto, a prova da omissão ou da ação, do dano e da relação de causalidade. Além disto, observa que, tendo em vista as características do bem tutelado - meio ambiente - o sistema jurídico adota a modalidade mais rigorosa de responsabilização civil, dispensando a prova de culpa. Ressalta ainda a não aceitação das excludentes de fato de terceiro, de culpa exclusiva da vítima e do caso fortuito e da força maior. Deste modo, caso o evento tenha ocorrido no curso ou, em razão de atividade potencialmente poluidora, incumbirá ao responsável a reparação de quais danos.

Steigleder destaca que este posicionamento também é sustentado por outros autores tais quais Millaré, Ferraz, Nery Jr., dentre outros, demonstrando ainda que o art. $14, \S 1^{\circ}$ da Lei $n^{\circ}$. 6938/81 prevê a incidência da responsabilização à qualquer atividade degradante e não somente às

excessiva atenção à vitima, acaba por negar o princípio da justiça social impondo cegamente o dever de repara equiparando o comportamento jurídico e antijurídico do agente. Ressalta, contudo, que tais criticas não procedem tendo em vista que o mero risco não gera dever de indenizar, devendo o mesmo estar em conjunto com a violação de um dever jurídico, qual seja, o dever de segurança, que se contrapõe ao risco. (CAVALIERI FILHO, op. cit., p.128 a 131)

${ }^{146}$ STEIGLEDER, op. cit., p. 198.

${ }^{147}$ Ibid. p. 198.

${ }^{148}$ BENJAMIN,op. cit., p. 41. 
perigosas, como ocorre no parágrafo único do artigo 927 do Código Civil vigente. ${ }^{149}$ Nicolao Dino de Castro e costa Neto também partilha do mesmo entendimento, afirmando que "a responsabilidade por dano ambiental é definida, a nosso ver, pela teoria do risco integral, sendo irrelevante a licitude da atividade, bem como a ocorrência de caso fortuito ou de força maior" 150

O Tribunal Regional Federal da $2^{a}$ região também já se pronunciou neste sentido ao decidir que "temos então que a obrigação de reparação do dano ambiental é objetiva (baseada no risco integral), solidária e imprescritível". ${ }^{151}$ O mesmo posicionamento, já adotou o Tribunal Regional Federal da $4^{\mathrm{a}}$ região, em decisão no seguinte sentido:

a industria agropecuária, na medida em que assume o rico de causar dano ao meio ambiente, com o simples desenvolvimento de sua atividade empresarial, assume a responsabilidade por eventuais defeitos no seu sistema de tratamento de efluentes, independentemente da sua vontade ou culpa. ${ }^{152}$

Segundo Cavalieri, devido ao extremo presente na teoria do risco integral, pela qual o dever de indenizar existe tão só em face do dano, persistindo ainda nos casos de fato de terceiro, culpa exclusiva da vítima e em casos fortuitos ou de força maior, esta será adotada pelo direito brasileiro apenas em situações excepcionais. ${ }^{153}$ Dentre estas, a hipótese de dano ambiental.

De acordo com o renomado jurista, o art. $225 \S 3^{\circ}$ da Constituição Federal de 1988 trata da responsabilidade dos causadores de danos ao meio ambiente e, neste ponto, não aponta como pressuposto a existência de culpa do degradante. Deste modo, demonstra que a Carta Magna recepcionou o art. $14, \S 1^{\circ}$ da Lei $n^{\circ}$. 6938/81 o qual expressamente dispõe acerca da desnecessidade da existência de culpa para que haja o dever de indenizar. Afirma, portanto, que, do sentido teleológico da Lei da Política Nacional do

\footnotetext{
${ }^{149}$ STEIGLEDER,op. cit,. p. 199.

${ }^{150}$ COSTA NETO, op. cit., p. 269.

${ }^{151}$ TRF $2^{\mathrm{a}}$ Região, Agravo de Instrumento $\mathrm{n}^{\mathrm{o}}$ 104105, ES, $4^{\mathrm{a}}$ Turma, Des. Relator Arnaldo Lima, j. 03.09.2003, DJU de 18.09.2003, p.167.

${ }^{152}$ TRF $4^{\mathrm{a}}$ Região, Apelação Cível n ${ }^{\mathrm{o}}$ 366723-SC, $4^{\mathrm{a}}$ Turma, Relator Juiz João Pedro Gebran Neto, j. 06.02.2002, DJU de 13.03.2002, p.1003.

${ }^{153}$ CAVALIERI FILHO, op. cit.,. p.130 e 131.
} 
Meio Ambiente (Lei $n^{o} .6938 / 81$ ) e do entendimento que se pode extrair do texto constitucional, tal "responsabilidade é fundada no risco integral, conforme sustentado por Nélson Nery Jr. (Justitia 126/74)". Esclarece ainda que, caso as causas excludentes da responsabilidade pudessem ser invocadas, a maior parte dos casos de poluição estaria à margem da incidência da lei, exemplificando com as hipóteses de destruição de flora e fauna causadas por cargas tóxicas de navios danificados em tempestades marítimas, rompimentos de oleodutos em circunstancias imprevisíveis, dentre outros. ${ }^{154}$

Todavia, conforme demonstra Steigleder, a adoção de tal teoria não se encontra pacificada na doutrina, sendo "contraposta pela teoria do risco criado, cujo diferencial mais evidente é a admissibilidade das excludentes de responsabilidade civil" ${ }^{155}$. Deste modo, há a possibilidade do rompimento do nexo de causalidade devido a culpa exclusiva da vítima, a força maior e aos fatos de terceiros. Tem-se, portanto, que, de acordo com a autora, tal teoria, em conjunto com a teoria da causalidade adequada, são utilizadas para explicar o nexo causal, tendo como sua noção central o elemento perigo.

A autora observa ainda que a teoria do risco criado, aplicada em diversos países, tais quais a Espanha, Itália, Portugal e Alemanha, foi acolhida pelo artigo 927, parágrafo único ${ }^{156}$, o Código Civil Brasileiro.

Além disto, nota que na Lei $n^{\circ}$. 6938/81 não há restrições do regime de responsabilidade objetiva às atividades perigosas, não sendo a periculosidade da atividade a justificativa principal para a adoção de um regime especial de responsabilização civil. O que fundamenta tal regime são as peculiaridades do dano ambiental e a sua proteção, tendo em vista o

\footnotetext{
${ }^{154}$ Ibid. p. 136 .

155 STEIGLEDER, op. cit., p. 199.

156 Art. 927. Aquele que, por ato ilícito (arts. 186 e 187), causar dano a outrem, fica obrigado a repará-lo. Parágrafo único. Haverá obrigação de reparar o dano, independentemente de culpa, nos casos especificados em lei, ou quando a atividade normalmente desenvolvida pelo autor do dano implicar, por sua natureza, risco para os direitos de outrem.
} 
caráter fundamental do direito ao meio ambiente ecologicamente equilibrado.

Partindo das premissas de que i) os custos decorrentes da prevenção e da reparação dos danos ambientais devam ser arcados por aqueles que exercem atividades econômicas e ii) as externalidades negativas não são geradas apenas por atividades perigosas, conclui a autora que a responsabilidade pelo risco aplica-se tanto aos danos gerados por uma atividade profissional qualquer, quanto pelos ocasionados por atividades que impliquem riscos. Evitando-se assim, a socialização dos riscos. ${ }^{157}$

Conforme explicitado anteriormente, na teoria do risco criado, busca-se a solução dos problemas existentes quanto ao nexo causal através da teoria da causalidade adequada, a qual se contrapõe a teoria da equivalência dos antecedentes, adotada pela teoria do risco integral.

De acordo com a teoria da causalidade adequada, elaborada por von Kries, se varias condições concorreram para a produção de determinado resultado, nem todas serão consideradas causas do mesmo, mas, apenas, a que for mais adequada à produção do evento. Deste modo, tem-se que causa será somente a que foi mais determinante, desconsiderando-se as demais, não bastando, portanto, "que o fato tenha sido, em concreto, uma condição sine qua non do prejuízo", sendo necessário, ainda, que o mesmo "constitua, em abstrato, uma causa adequada ao dano". ${ }^{158}$ Seleciona-se assim, entre as diferente causas que podem ter motivado o dano, aquela que apresente as maiores probabilidades de ter criado um risco socialmente inaceitável. ${ }^{159}$

De outro modo, na teoria da equivalência dos antecedentes, também chamada de teoria da conditio sine qua non, não há distinção entre causa e condição de modo que, se várias condições concorrerem para um determinado resultado, todas elas terão a mesma relevância, não se indagando se uma delas foi mais ou menos adequada para a produção do

\footnotetext{
${ }^{157}$ STEIGLEDER, op. cit., p. 201.

158 CAVALIERI FILHO, op. cit., p.48.

159 STEIGLEDER,op. cit., p. 202.
} 
evento danoso. A técnica utilizada para saber se determinada condição é ou não causa, é através de um processo hipotético em que se exclui mentalmente determinada condição. Se o resultado persistir, não será causa. Do contrário, estaremos diante de uma das causas para a produção do dano. 160 e 161

Tal qual expõe Steigleder, e conforme dito anteriormente, a teoria do risco integral se vale desta última para aferição do liame do nexo causal, bastando que o dano possa estar vinculado a uma atividade que gere risco para que o evento condicionante seja equiparado à causa do prejuízo. Logo, não se exige que o mesmo seja conseqüência direta, imediata e necessária do evento. ${ }^{162}$

Com isto, percebe-se a atenuação do nexo de causalidade o qual se transforma em mera "conexão" entre o dano e a atividade. Além disto, todos os riscos decorrentes de uma atividade deverão ser intenalizados e, caso haja a ocorrência do evento danoso, persistirá a presunção e causalidade entre os riscos e o dano. Contudo, esclarece a autora que

\begin{abstract}
tal dano deverá estar estreitamente vinculado à atividade profissional do responsável, vislumbrando-se uma conexão entre a lesão ambiental e os riscos próprios da atividade empresarial ou estatal, pois 'o agente não responderá por certo dano quando possa provar que, em face das circunstâncias concretas, ele se daria houvesse ou não o fano danoso'. Esta conexão é presumida e extraída dos princípios da precaução e do poluidor-pagador, com o que se redefine os objetivos da responsabilidade civil. ${ }^{163}$
\end{abstract}

A autora assinala ainda que a prova da existência de um nexo de causalidade o dano e a atividade poluente, por vezes, é tarefa bastante árdua tendo em vista que, na maioria das vezes, não se encontra ligação direta entre ambos. Logo, a necessidade de responsabilização integral pelos riscos gerados admitindo-se a substituição da certeza necessária para a

\footnotetext{
${ }^{160}$ CAVALIERI FILHO, op. cit., p.47.

${ }^{161}$ Tal teoria foi elaborada por von Buri, baseada nas idéias de Stuart Mill tendo aplicação do Direito Penal de vários países, inclusive, no nosso. Seus defensores sustentam que o resultado "é sempre uno e indivisível" de modo a ser impossível a sua atribuição "a cada uma das condições isolada e autonomamente. Logo, todas as condições antecedentes necessários do resultado, se equivalem". (CAVALIERI FILHO, Sergio. Programa de Responsabilidade Civil. $7^{\mathrm{a}}$ ed. São Paulo: Atlas, 2007. p.47)

${ }^{162}$ STEIGLEDER, op. cit., p. 202.

${ }^{163}$ Ibid. p. 204.
} 
determinação de uma causa adequada pela probabilidade e pela conexão entre o dano e os riscos inerentes à atividade. ${ }^{164}$

Steigleder salienta a existência de outras teorias sobre a causalidade, desenvolvidas pela doutrina visando à facilitação da prova do liame causal. Para tanto, menciona a Lei Alemã, de 10 de dezembro de $1990^{165}$, que trata da Responsabilidade sobre o Meio Ambiente ${ }^{166}$, a qual, embora não adote a teoria da responsabilidade civil objetiva, estabelece hipóteses de presunção do nexo de causalidade. Contudo, tal diploma legal dispõe que tal presunção deixa de existir caso a instalação funcione de acordo com as normas ou caso seja constatada outra circunstância apta a causar o dano ambiental. ${ }^{167}$

Leme Machado leciona que, na Itália, de acordo com o artigo "L'inversione dell'onere della prova nel Diritto Civile", os tribunais estão propensos a relacionar diretamente o dano às atividades que resultem disciplinadas pela responsabilidade civil objetiva. "Dizem os autores que,

\footnotetext{
${ }^{164}$ Ibid. p. 205 e 206.

${ }^{165}$ Steigleder, ao fazer referência à Lei de Responsabilidade sobre o Meio Ambiente, cita a Lei Alemã de 12 de outubro de 1990. Contudo, em pesquisa, foi verificado que a mesma é de $10 \mathrm{de}$ dezembro do mesmo ano e não de 12 de outubro como mencionado.

${ }^{166}$ Lei de Responsabilidade sobre o Meio Ambiente, de 10 de dezembro de 1990. Alemanha. PARÁGRAFO 6.: Presunção do nexo de causalidade ( 1 ) Se a instalação for apta a, dadas as circunstâncias do evento, causar os danos verificados, presume-se tê-los causado. Essa aptidão avalia-se com base nos tipos e tempo da laboração, nas instalações utilizadas, nos teor e concentração nos produtos utilizados ou libertados, nas condições meteorológicas, nos tempo e lugar do evento danoso, na forma como este de deu, bem como em outros dados que, no concreto, a revelem. ( 2 ) O disposto em ( 1 ) não tem aplicação quando a instalação funcionar dentro das normas. Uma instalação funciona segundo as normas, quando são respeitadas as regras especiais da laboração e não ocorre nenhum acidente nesta. ( 3 ) Regras especiais de laboração são aquelas que resultam das licenças administrativas, de imposições e de disposições ou prescrições vinculativas, destinadas a impedir acções sobre o ambiente como aquela que produziu o dano em causa. ( 4 ) Se nessas licenças, imposições, disposições ou prescrições vinculativas, forem exigidas especiais obrigações de fiscalização no controle da laboração, presumir-se-á o respeito dessas obrigações quando: 1) Os controles foram respeitados na área de laboração da instalação da qual poderiam provir as acções sobre o ambiente em causa e esses controlos nã revelam qualquer desrespeito das normas de laboração 2) A acção sobre o ambiente tiver sido praticada há mais de dez anos relativamente à altura em que é exercido o direito à reparação dos danos. PARÁGRAGO 7.': Exclusão da presunção. ( 1 ) Se forem várias as instalações aptas a causar os danos, não funcionará a presunção se, tendo em conta os danos do caso concreto, uma outra circunstância for apta a causar danos. A aptidão avalia-se, no concreto, pelo local e tempo do acontecimento danoso, pela forma como este se deu, bem como por todos os outros factores que no caso concreto a revelem. ( 2 ) Se só uma das instalações for apta a causar danos, não funcionará a presunção se, tendo em conta os danos do caso concreto, uma outra circunstância for apta a causá-los. legislação disponível em português no site http://www.diramb.gov.pt, acessado em 26 de outubro de 2007.

${ }^{167}$ STEIGLEDER, op. cit., p. 206.
} 
em relação à poluição, foi decidido que 'diante da violação de um standard previsto em relação ao lançamento de agentes potencialmente poluidores na água de um rio, o dano que seja derivado da alteração da água será ligado, como causa, à mencionada violação'. Demonstra portando que o tribunal italiano dispensou a prova quanto ao nexo causal tendo em vista a presunção de causalidade quando se trata de responsabilidade objetiva. ${ }^{168}$

A autora menciona Antonio Menezes Cordeiro, o qual aponta a substituição da teoria da causalidade adequada pela causalidade normativa, a qual pode ser enquadrada na fórmula que prescreve que, partindo-se de uma condição sine qua non, cabe indagar se tais danos correspondem aos bens tutelados pelas normas violadas. Caso os danos correspondam às posições garantidas pelas diretrizes infringidas, serão os mesmos imputados ao agente. $\mathrm{O}$ referido autor assinala também a existência de outras teorias, tais quais a da causalidade estatística ${ }^{169}$ e da causalidade alternativa ${ }^{170} .^{171}$

Alude ainda à posição de Carlos de Miguel Perales o qual indica e existência de diversas outras teorias tais quais a teoria a) da condição perigosa, b) teoria da proporcionalidade, c) da responsabilidade de participação no mercado e d) da causalidade alternativa. ${ }^{172}$

Acredita Steigleder que, quanto ao direito brasileiro, dentre estas, apenas a teoria da causalidade alternativa pode ser adotada tendo em vista que a solidariedade passiva por danos ambientais é matéria já consolidada tanto na doutrina quanto na jurisprudência e na legislação (art. $3^{\circ}$, inciso IV, da Lei $n^{\circ}$. 6938/81), baseando-se na unidade e indivisibilidade do dano ambiental. ${ }^{173}$

Benjamin adota a mesma posição, dispondo que o Direito Ambiental, no que se refere à teoria da causalidade alternativa, reformula o sistema da

\footnotetext{
${ }^{168}$ LEME MACHADO, op. cit., p. 354 e 355.

${ }^{169}$ A teoria da causalidade estatística pode ser entendida como, ultrapassando-se a condição sine qua non, se torna aparente em um conjunto de fatos homogêneos quando tomados um por um. ${ }^{170}$ A teoria da causalidade alternativa estabelece a possibilidade de responsabilização solidária de todos aqueles que contribuem com um dano na medida em que quando dois agentes tenham dado causa a um dano, ainda que não se saiba qual, respondem ambos.

${ }^{171}$ STEIGLEDER, op. cit., p. 207.

172 Ibid. p. 207.

${ }^{173}$ Ibid. p. 208.
} 
responsabilidade civil, defendendo a impossibilidade de se deixar a vítima de um dano ambiental sem a devida reparação. Demonstra ainda que a doutrina clássica já aceitava a hipótese de todos responderem quando vários sujeitos participarem de um mesmo ato em cuja execução, um dos participantes gere o dano. Como ilustração, exemplifica com a hipótese dos distritos industriais, em que diversas indústrias que lá operam, ainda que independentes entre si, participam de uma atividade industrial comum. ${ }^{174}$

${ }^{174}$ BENJAMIN, op. cit., p. 46. 


\section{Problemática}

Não obstante a importância do instituto da responsabilidade civil ambiental, há diversas barreiras a serem transpostas pelo mesmo visando a possibilidade de reparação integral do bem jurídico tutelado. De acordo com Gonçalves ${ }^{175}$, esta reparação do dano ambiental pode consistir na a) indenização dos prejuízos, legalmente presumidos ou legais ou b) restauração do que foi poluído, degradado ou destruído. Deste modo, há a possibilidade de a responsabilidade do réu ter caráter repressivo, em relação à lesão já consumada, ou preventivo, em relação à sua consumação eminente.

Neste sentido, dispõe Leuzinger, acrescentando ainda que, com base no princípio da reparação integral, o ideal é que se busque, primeiramente, a recuperação do meio ambiente ou a sua reconstrução. Como medida secundária, não sendo possíveis tais providências, admite-se a indenização em dinheiro o qual será destinado a um fundo ${ }^{176}$ de meio ambiente. Ressalta ainda que, na busca pela reparação total, pode ocorrer a aniquilação da

\footnotetext{
175 GONÇALVES, Carlos Roberto. Direito Civil Brasileiro. V.IV: responsabilidade civil. São Paulo: Saraiva, 2007. p. 78

${ }^{176}$ De acordo com Álvaro Mirra, a Lei $n^{\circ} .7 .347 / 85$ inova no âmbito da responsabilidade civil por danos ao meio ambiente, estabelecendo, em seu art. 13, caput, que havendo condenação em dinheiroa indenização pelo dano ambiental será revertida para um fundo gerido por Conselhos Estaduais ou por um Conselho Federal dos quais participarão o Ministerio Público e representantes da comunidade, sendo seus recursos destinados à reconstituição dos bens lesados. Na esfera Federal, tal fundo encontra-se regulamentado pelo Decreto ${ }^{\circ}$. 1.306/94, o qual o denomina Fundo de Defesa de Direitos Difusos tendo seu conselho gestor sido criado pela Lei no . 9.008/95. Observa o autor que para o fundo gerido pelo Conselho Federal, "devem ser destinadas as quantias em dinheiro resultantes de condenações obtidas em ações civis públicas ambientais ajuizadas perante a Justiça Federal”. Já aos fundos geridos pelos Conselhos Estaduais, deverá ser destinado o montante obtido em consenações proferidas em ações civis públicas movidas perante a Justiça Estadual. De acordo com o autor, os recursos do fundo "têm por finalidade a reparação dos danos causados ao meio ambiente (art. $1^{\circ}$ do Decreto n. $1.306 / 94$ e art. $1^{\circ}, \S 1^{\circ}$, da Lei n. 9.008/95), e, após a sua arrecadação, devem, em conformidade coma Lei n. 7.347/85 (art. 13), o Decreto n. 1.306/94 (arts. $7^{\circ}$ e 10 , parágrafo único) e a Lei n. 9.008/95 (art. $1^{\circ}, \$ 3^{\circ}$ ), ser utilizados prioritariamente na reparação específica do prejuízo que deu origem à condenação, no local da sua ocorrência". Adverte o autor ainda que o uso do dinheiro de condenações em atividades outras que não a recomposição da qualidade ambiental degradada não está autorizado legalmente Para estas atividades (perícias judiciais, modernização de orgãos públicos responsáveis pelas políticas relativas à proteção do meio ambiente, dentre outras), existem dotações outras, do próprio fundo, tais quais as "doações de pessoas físicas ou jurídicas, nacionais e estrangeiras (art. $2^{\circ}$, VII e VIII, do Decreto n. 1.306/94 e art. $1^{\circ}$, $\S 2^{\circ}$, VII e VIII, da Lei n. 9.008/95), e do Fundo Nacional do Meio Ambiente, criado pela Lei n. 7.797/89". (MIRRA, Álvaro Luiz Valery. Ação civil pública e reparação do dano ao meio ambiente. $2^{\mathrm{a}}$ edição. São Paulo: Juarez de Oliveira 2004. p. 358-363)
} 
capacidade econômica do agente, não devendo tal fato ser tido como óbice para a recomposição do bem. ${ }^{177}$

Contudo, ainda que incansável a busca por mecanismos que promovam a reparação integral, determinadas peculiaridades do dano ambiental se impõem como óbices para a responsabilização dos agentes.

Todavia, conforme demonstra Gonçalves ${ }^{178}$, não mora a maior dificuldade nos casos de lesões por intermédio do meio ambiente, tendo em vista que, nestes casos, a exigência de certeza do dano e da pessoalidade do mesmo poder suprida com maior facilidade. De modo diverso, no caso de danos ambientais autônomos, o preenchimento dos requisitos é tarefa árdua tendo em vista as peculiaridades destas lesões.

Como exemplos de danos ambientais autônomos, temos a poluição atmosférica, os danos nucleares, a contaminação da água por óleo, do lençol freático por agrotóxicos, dentre outros, inúmeros e não menos importantes.

Em todos estes casos, como se pode perceber, as situações acabam por ir além das relações de direito privado existentes tendo em vista que se está diante de vítimas difusas. De acordo com Benjamin ${ }^{179}$, isto ocorre por ser comum a chamada causalidade diferida ou retardada, em que o dano se manifesta muitos anos após a realização da conduta, a qual será, ainda assim, punível tendo em vista a proteção jurídica dada tanto aos sujeitos apenas concebidos, quanto às futuras gerações. Além disto, cumpre observar que o dano ambiental não respeita os limites geográficos, sendo caracterizado como transfronteiriço de modo que a poluição originada em determinada região poderá ter seus efeitos presentes em outra localidade.

Inclui-se ainda dentre o rol de vítimas, a própria natureza, autonomamente considerada tal qual afirma a Lei $n^{\circ}$. 6938/81 a qual dispõe ainda acerca da possibilidade de, nestes casos, a saúde e o patrimônio dos indivíduos serem também atingidos.

\footnotetext{
${ }^{177}$ LEUZINGER, op. cit., p. 190.

${ }^{178}$ GONÇALVES, op. cit., p. 78.

${ }^{179}$ BENJAMIN, op. cit.,. p. 39.
} 
Contudo, quanto ao dano ecológico puro, diversas questões se impõem. Como verificar tais danos? Será que os instrumentos disponíveis na época do estudo do dano serão suficientes para que se percebam todas as facetas do mesmo, inclusive seus efeitos futuros? Como saber se o dano visível é a totalidade do mesmo ou apenas uma ponta do iceberg? Como mensurar tais lesões ao meio ambiente? Há como valorar a natureza em si mesma considerada nas hipóteses em que não há como retornar ao status quo ante?

No presente ano de 2007, diversas novas espécies de animais foram descobertas. Chondrostoma olisiponensis, em afluentes do rio Tejo ${ }^{180}$. Mais de 30 espécies de peixes na bacia do Alto Paraná ${ }^{181}$. Nova espécie de morcego frugívoro nas Filipinas ${ }^{182}$. Se houvesse sido realizada, em 2006, uma avaliação dos danos ambientais ocorridos, certamente tais espécies não teriam sido consideradas. Tal quadro certamente se repetirá daqui a alguns anos, quando pesquisadores e cientistas descobrirão espécies de animais e plantas desconsiderados no momento da fixação, na data de hoje, da obrigação do agente poluidor. A ausência de conhecimento científico em determinada época acaba por fazer com que a indenização ou a reparação do dano não ocorra de forma suficiente. Deste modo, tem-se que a certeza, quando se trata de dano ambiental, é algo relativo, dependendo de considerações acerca da totalidade dos impactos, os quais, muitas vezes, são imensuráveis tendo em vista a tecnologia disponível e a complexidade das lesões.

Ademais, freqüente ainda é a existência de causas difusas para a ocorrência de uma lesão ambiental, tal qual a degradação provocada por um autor indeterminado dentre um grupo de sujeitos determinado como na poluição decorrente de um conglomerado de indústrias.

\footnotetext{
${ }^{180} \mathrm{http}: / /$ ultimahora.publico.clix.pt/noticia.aspx?id=1308542 acesso em 05 de novembro de 2007.

$181 \mathrm{http} / /$ www.faunabrasil.com.br/sistema/modules/news/article.php?storyid=1168 acesso em 05 de novembro de 2007.

182 http://www.faunabrasil.com.br/sistema/modules/news/article.php?storyid=1128 acesso em 05 de novembro 2007
} 
Outra possibilidade é a ocorrência de danos causados por sujeitos indeterminados dentre um grupo de sujeitos também indeterminado. Como exemplos de danos anônimos, em que as causas também são difusa, há a emissão de veículos nas grandes cidades, as chuvas ácidas, a poluição hídrica em meio urbano, dentre outras, havendo um concurso de concausas dificilmente identificáveis. Além destes, Lamac recorda a questão da nuvem de poluição que paira no sul da Ásia,

causada sabe-se lá por quais indústrias, usinas termelétricas, automóveis e outros tipos de emissores, a poluição dos rios e mares por esgotos e dejetos de todo tipo, o fogo que vorazmente extermina os parcos remanescentes florestais trazendo a desertificação, os agrotóxicos que contaminam os alimentos, o solo e os lençóis freáticos, o comprometimento da biodiversidade com o extermínio de espécies em razão da poluição do ar, da água, desmatamentos, construção de usinas hidrelétricas e até mesmo os vários casos de contaminação de solos por produtos químicos e radioativos que vêm sendo constantemente divulgados. ${ }^{183}$

Por outro lado, pode ocorrer ainda de o dano ambiental ser derivado de atividades que cumprem os limites para a emissão de poluentes. Isto se dá devido ao fato de as doses máximas toleráveis serem geralmente fixadas para cada poluente, isoladamente considerado, sem que se observe a sua interação com outras substancias que se misturam na natureza, acumulandose nos organismos vivos. Além disto, as doses geralmente são fixadas em abstrato sem que sejam consideradas as especificidades do local e os riscos invisíveis quando não, por vezes, são apenas frutos de negociações, visando atender os interesses dos setores industriais. Logo, as substâncias que individualmente consideradas seriam inofensivas, ao se misturarem, dão ensejo à lesão ao meio ambiente, ocorrendo a contaminação por sinergia. Neste contexto, como responsabilizar os agentes, tendo em vista que todas as empresas encontram-se licenciadas ambientalmente e cumprem os padrões por lei estabelecidos? Caberia a fixação do valor da indenização para cada poluidor, na medida em que contribuiu para o dano?

Outra dificuldade que se impõe é decorrente da possibilidade de o dano ambiental ser futuro, rompendo-se com o requisito da atualidade,

${ }^{183}$ LAMAC, Jaques. Responsabilidade Ambiental do Estado: Aspectos Administrativos. In Revista de Direitos Difusos, São Paulo, ano IV, v. 17, 2003, p. 2271. 
necessário em se tratando da responsabilidade civil tradicional. Tratando-se de dano individual, em que a atenção incide sobre a vítima, os efeitos de determinadas ações possuem o limite temporal determinado pela vida da pessoa de modo que os efeitos da lesão a saúde do individuo poderá transparecer muito tempo após a causa da mesma. Como saber, portanto que a ingestão de determinada substancia ou de determinado produto foi o causador de uma doença futura? Como estabelecer tal nexo de causalidade quando há a possibilidade de diferentes substâncias terem sido a causa da doença? E, ainda, como saber se não foi a conjunção de determinadas substancias que causou o dano não se olvidando a dificuldade em se determinar quais serias estas substancias?

De acordo com Steigleder ${ }^{184}$, quando se trata de danos ambientais em sentido amplo, tais problemas aumentam em grande escala tendo em vista as inúmeras variáveis que entram em cena. Se afeta, nestes casos, não apenas um indivíduo, mas todo um ecossistema cujas interações não se dão a curto prazo, mas por séculos. Assim, torna-se tarefa bastaste árdua, senão impossível, que sejam considerados todos os efeitos no momento em que se prolata a sentença. Poderão os efeitos futuros, mas que guardam relação de causalidade com a fonte original do impacto, quedar sem reparação? E os riscos invisíveis? Não deverão aqueles que se caracterizam pela imprevisibilidade de seus efeitos nocivos, ainda separados tanto pelo tempo quanto pelo espaço da fonte degradante, serem reparados?

Steigleder ${ }^{185}$ observa assim que o

reconhecimento da dimensão futura do dano ambiental enseja a discussão acerca da responsabilização sem dano, em que se quer, não a indenização, já que não há dano a ser reparado, mas a supressão do fator de risco existente em uma atividade intrinsecamente perigosa.

Exemplifica tal situação com o caso das usinas nucleares em que, caso consumado o dano, os efeitos serão catastróficos não devendo ser

\footnotetext{
${ }^{184}$ STEIGLEDER, op. cit., p. 142-143.

${ }^{185}$ Ibid.. p. 143.
} 
esperada a lesão para que se justifiquem medidas de precaução e prevenção. 186

Tendo em vista que o dano ambiental possui caráter difuso, trazendo repercussões de maneira lenta e gradual e sendo, geralmente, indireta e mediata a relação entre poluidor e vítima, como se estabelecer o nexo causal entre a atuação e o dano?

Outra grande dificuldade que se impõe é quanto à origem da lesão ambiental a qual pode ser derivada de causas concorrentes, simultâneas e sucessivas, tais como os danos causados pelas cargas ambientais acumuladas, (como, p.ex., depósitos antigos de resíduos) ${ }^{187}$. Nestes casos, bem como nos casos de danos causados à distância, como configurar o binômio causa-efeito? Consequentemente, como identificar os sujeitos passivos da ação reparatória ambiental?

Conforme ressalta Benjamin ${ }^{188}$, apenas afirmar que será sujeito passivo o degradante, não soluciona o problema. Aparentemente fácil no plano teórico-abstrato, tal resposta é extremamente penosa quando se passa a sua análise no plano fático. Saber de forma exata quem o é, no momento de sua utilização concreta, consiste uma das maiores dificuldades no Direto Ambiental.

Diante de tamanhas dificuldades, impõe-se apenas uma certeza: tendo em vista a titularidade difusa do bem e a indisponibilidade do mesmo, não pode o meio ambiente lesado ficar sem recuperação ou, em última instância, não será plausível que a apropriação pelo poluidor dos direitos de outrem lhe seja gratuita, sendo devida, na impossibilidade de recomposição do bem lesado, no mínimo, indenização.

Conforme demonstra Krell, temas muito discutidos no âmbito da responsabilidade objetiva por dano ambiental são a inversão do ônus da prova para o lado do potencial poluidor; a valoração do dano ecológico, isto é, a definição do valor monetário a ser pago pelo poluidor por danos

\footnotetext{
${ }^{186}$ Ibid.. p. 143 e 144.

${ }^{187}$ LEITE, op. cit., p. 67.

${ }^{188}$ BENJAMIN, op. cit., p. 37.
} 
causados ao ambiente e à paisagem bem como a dificuldade na determinação da participação concreta de cada um de múltiplos poluidores (por ex.: em pólos industriais); ${ }^{189}$

Reconhecendo isto, demonstra Athias que

uma das maiores dificuldades que se pode ter em ações relativas ao meio ambiente é exatamente determinar de quem partiu efetivamente a emissão que provocou o dano ambiental, máxime quando isso ocorre em grandes complexos industriais onde o número de empresas em atividade é elevado. Não seria razoável que, por não se poder estabelecer com precisão a qual deles cabe a responsabilização isolada, se permitisse que o meio ambiente restasse indene. ${ }^{190}$

Tendo em vista estas premissas e os obstáculos existentes, tal qual a a identificação dos sujeitos da relação obrigacional, a (in)existência, quando do aparecimento dos efeitos da lesão, do degradante e a solvência do mesmo, o Direto Ambiental brasileiro optou, além da adoção da responsabilidade civil objetiva, pela ampliação do rol dos sujeitos responsáveis adotando-se a solidariedade entre eles e, ainda, abrindo-se, ainda, a possibilidade de desconsideração da pessoa jurídica. ${ }^{191}$

Conforme ensina Steigleder,

conhecendo-se a identidade das fontes geradoras da contaminação, aplicam-se a elas o regime da responsabilização civil objetivo e o princípio da solidariedade entre os co-poluidores, apreendido mediante interpretação dos arts. 258, 259, 275 e 942 do novo código Civil. ${ }^{192}$

Acrescenta a autora que tais normas consideram o dano ambiental como um fato único e indivisível, impossibilitando sua fragmentação e acarretando, desta forma, um nexo causal comum.

Tendo em vista a freqüente pluralidade de agentes quando se trata de dano ambiental, o direito brasileiro oferece como solução a possibilidade de responsabilização in solidum dos co-responsáveis, não tendo assim a Lei $n^{\circ}$. 6.938/81 desviado do princípio da solidariedade passiva estabelecido no Código Civil vigente. Cabe, portanto, a responsabilização solidária de

\footnotetext{
${ }^{189}$ KRELL, op. cit., p.22-37.

190 ATHIAS, Jorge Alex Nunes. Responsabilidade Civil e Meio Ambiente - breve panorama do direito brasileiro. In BENJAMIN, Antonio Herman (coord.). Dano ambiental: prevenção, reparação e repressão. São Paulo: Editora Revista dos Tribunais, 1993. p. 244.

${ }^{191}$ BENJAMIN,op. cit., p. 39.

192 STEIGLEDER, op. cit., p. 217.
} 
todos aqueles que contribuíram para a ocorrência do dano, não cabendo a escusa do réu sob o fundamento de não ser apenas ele o agente degradante, não sendo possível a identificação daquele que efetivamente desencadeou o prejuízo. ${ }^{193}$

De acordo com Nery Jr, não será necessário que se demonstre concerto prévio e comunhão de desígnios para que haja a responsabilidade solidária dos poluidores tendo em vista que a mesma decorre de lei. ${ }^{194}$

Admitindo-se a solidariedade entre os agentes degradantes, prevista pelo art. 942, caput, do Código Civil de 2002, e a ampliação do rol dos sujeitos responsáveis, visando um a maior chance de se encontrar um responsável solvente que tenha capacidade para reparar a lesão, é mister que se conceitue àqueles que possam ser sujeitos passivos de uma ação reparatória ambiental.

Assim, estatui a Lei $n^{\circ} .6 .938 / 81$, em seu art. $3^{\circ}$, inciso IV, que

Art $3^{\circ}$ - Para os fins previstos nesta Lei, entende-se por:

IV - poluidor, a pessoa física ou jurídica, de direito público ou privado, responsável, direta ou indiretamente, por atividade causadora de degradação ambiental;

Deste modo, conforme leciona Benjamin, tem-se que "poluidor" passa a ser um vocábulo amplo, incluindo

aqueles que diretamente causam o dano ambiental (o fazendeiro, o madereiro, o ninerador, o especulador), bem como os que indiretamente com ele contribuem, facilitando ou viabilizando a ocorrência do prejuízo (o banco, o órgão público licenciador, o engenheiro, o arquiteto, o incorporador, o corretor, o transportador, para citar alguns personagens). ${ }^{195}$

Tem-se, portanto, que a Lei $n^{\circ}$. 6938/81 acaba por generalizar o regime da responsabilidade objetiva, obrigando todo e qualquer poluidor, direto ou indireto, independente da existência de culpa, a reparar ou, em

\footnotetext{
${ }^{193}$ BENJAMIN, op. cit., p. 38.

${ }^{194}$ NERY JUNIOR, Nelson; NERY, Rosa Maria B. B. de Andrade. Responsabilidade Civil, Meio ambiente e Ação Coletiva Ambiental. In BENJAMIN, Antonio Herman (coord.). Dano ambiental: prevenção, reparação e repressão. São Paulo: Editora Revista dos Tribunais, 1993, p.288.

195 BENJAMIN, op. cit., p. 37.
} 
ultimo caso, indenizar, os danos causados ao meio ambiente e a terceiros afetados por sua atividade. ${ }^{196}$

Neste sentido, das lições de Pasqualotto, apreende-se que

se alguém, por sua atividade, cria determinado risco de dano, deve responder pelos prejuízos que dessa atividade advierem, independentemente de haver causado o fato que diretamente produziu o resultado lesivo. ${ }^{197}$

Percebe-se assim que, com a inclusão no rol dos sujeitos passivos do poluidor indireto e tendo em vista a opção do legislador pela responsabilidade civil objetiva com a adoção da teoria do risco, que, de acordo com a teoria da causalidade adotada, flexibiliza mais ou menos o nexo causal e admite-se ou não as excludentes de responsabilidade, pode-se chegar a uma responsabilização infinita.

Assim, flexibilizando-se demasiadamente o nexo causal e não se admitindo as excludentes de responsabilidade, possível será uma responsabilização injusta de determinados agentes. Por outro lado, tornando demasiadamente rígida a relação de causalidade e admitindo-se as excludentes pode-se chegar uma situação de irreparabilidade, por todo exposto, inaceitável, do dano ambiental. Urge, portanto, a limitação do atual conceito amplo de poluidor indireto de modo a se chegar a uma solução, por todo, justa.

\footnotetext{
${ }^{196}$ PASQUALOTTO, op. cit.,. p.450.

${ }^{197}$ Ibid. p.448.
} 


\section{A Responsabilidade Civil Ambiental do Poluidor Indireto - Análise de casos.}

\subsection{A co-responsabilidade dos poluidores indiretos}

Embora a legislação brasileira e o entendimento doutrinário dêem subsídios para a responsabilização civil pelo dano ambiental do poluidor indireto, não há entendimento pacífico acerca de quem poderá figurar no pólo passivo de uma ação reparatória ambiental.

Todavia, identificadas as fontes da degradação, a elas aplicam-se o regime da responsabilidade civil objetiva e o princípio da solidariedade entre os co-poluidores "apreendido mediante interpretação dos arts. 258, 259, 275 e 942 do Código Civil Brasileiro”. ${ }^{198}$

De acordo com tais dispositivos legais, a obrigação será indivisível quando sua prestação tiver por objeto uma obrigação não suscetível de divisão, dentre outros motivos, por sua natureza, tal qual ocorre com a degradação ambiental que é considerada fato danoso indivisível e único. Neste caso, havendo dois ou mais devedores, cada um será obrigado pela dívida em sua integralidade, podendo o credor exigir a prestação de apenas um ou de todos os devedores, ressalvando-se, contudo, o direito de regresso daquele que pagou contra os que não efetuaram o pagamento.

Assim, responsáveis solidários serão os poluidores diretos e indiretos, os quais serão considerados co-autores e serão obrigados pela reparação em sua totalidade, sendo facultada a cobrança de tal prestação de um ou de todos aqueles que produziram o dano ambiental.

Para Benjamin,

a solidariedade, no caso, é não só decorrência de atributos particulares dos sujeitos responsáveis e da modalidade de atividade, mas também da própria indivisibilidade do dano, conseqüência de ser o meio ambiente uma unidade infragmentável. A responsabilização in solidum, em matéria ambiental, encontra seu fundamento originário no Código Civil, na teoria geral dos atos ilícitos; com maior ímpeto e força reaparece na norma constitucional, que desenhou de forma indivisível o meio ambiente, 'bem de uso comum de todos' cuja ofensa estão os 'poluidores' (no plural mesmo) obrigados a reparar, propiciando, por isso mesmo,

${ }^{198}$ STEIGLEDER, op. cit., p. 217. 
a aplicação do art. 892, primeira parte, do Código Civil, sendo credora a totalidade da coletividade afetada. ${ }^{199}$

Dispõe ainda Steigleder que a solidariedade entre os co-poluidores deverá existir ainda que não seja possível estabelecer de forma precisa a contribuiçãa causal de cada uma das fontes degradadoras tal qual se dá nos casos em que o dano ocorre de forma progressiva e lenta. ${ }^{200}$

Todavia, embora admitindo a solidariedade passiva entre as fontes poluidoras, o Superior Tribunal de Justiça faz ressalva a mesma, em decisão recente, tendo em vista a insurgência de poluidoras contra a obrigação de reconstituição de todo o meio ambiente, sob o argumento de que cada mineradora poluiu apenas determinada área e, comprovando tal fato na peça exordial, decidiu o STJ que "havendo mais de um causador de um mesmo dano ambiental, todos respondem solidariamente pela reparação, na forma do art. 942 do Código Civil. De outro lado, se diversos forem os causadores da degradação ocorrida em diferentes locais, ainda que contíguos, não há como atribuir-se a responsabilidade solidária adotando-se apenas o critério geográfico, por falta de nexo causal entre o dano" ${ }^{201}$.

Fundamenta-se tal decisão nos seguintes termos:

\footnotetext{
${ }^{199}$ BENJAMIN, op. cit., p. 38.

${ }^{200}$ STEIGLEDER,op. cit., p. 218.

201 STJ, Segunda Turma, REsp 647.493-SC , Rel. Min. João Otávio de Noronha, j. 22/05/2007, v.u., DJ 22/10/2007. Dispõe a ementa que: "RECURSO ESPECIAL. AÇÃO CIVIL PÚBLICA. POLUIÇÃO AMBIENTAL. EMPRESAS MINERADORAS. CARVÃO MINERAL. ESTADO DE SANTA CATARINA. REPARAÇÃO. RESPONSABILIDADE DO ESTADO POR OMISSÃO. RESPONSABILIDADE SOLIDÁRIA. RESPONSABILIDADE SUBSIDIÁRIA.

1. A responsabilidade civil do Estado por omissão é subjetiva, mesmo em se tratando de responsabilidade por dano ao meio ambiente, uma vez que a ilicitude no comportamento omissivo é aferida sob a perspectiva de que deveria o Estado ter agido conforme estabelece a lei.

2. A União tem o dever de fiscalizar as atividades concernentes à extração mineral, de forma que elas sejam equalizadas à conservação ambiental. Esta obrigatoriedade foi alçada à categoria constitucional, encontrando-se inscrita no artigo $225, \S \S 1^{\circ}, 2^{\circ}$ e $3^{\circ}$ da Carta Magna.

3. Condenada a União a reparação de danos ambientais, é certo que a sociedade mediatamente estará arcando com os custos de tal reparação, como se fora auto-indenização. Esse desiderato apresenta-se consentâneo com o princípio da eqüidade, uma vez que a atividade industrial responsável pela degradação ambiental - por gerar divisas para o país e contribuir com percentual significativo de geração de energia, como ocorre com a atividade extrativa mineral - a toda a sociedade beneficia.

4. Havendo mais de um causador de um mesmo dano ambiental, todos respondem solidariamente pela reparação, na forma do art. 942 do Código Civil. De outro lado, se diversos forem os causadores da degradação ocorrida em diferentes locais, ainda que contíguos, não há como atribuir-se a responsabilidade solidária adotando-se apenas o critério geográfico, por falta de
} 
Insurgem-se as recorrentes contra a obrigação de reconstituir todo o meio ambiente degradado de forma solidária, ao fundamento de que cada mineradora poluiu apenas parte da área indicada na peça vestibular. Assim, pretendem que a responsabilidade do cumprimento obrigacional seja atribuída a cada empresa no que efetivamente houver sido por ela degradado.

$\mathrm{Na}$ sentença, houve oportunidade de se decidir sobre a questão, tendo o magistrado adotado a tese de que a poluição perpetrada é una, conforme demonstra o trecho a seguir transcrito:

"Deixou-se antes assentado que a responsabilidade por dano ambiental é solidária, mas esta solidariedade encontra limites na configuração do dano e no correlato dever de indenizar. $\mathrm{O}$ dano causado ao ar, à terra e às águas da região carbonífera é um só, e afeta todo o ecossistema. Embora tenha se aperfeiçoado ao longo do tempo, é uno, indivisível e tem como causa fundamental a mineração. Sabe-se que esta degradação ocorreu em razão direta da atividade mineraria, mas não se sabe exatamente se foi esta ou aquela quem mais poluiu" (fl. 1.555).

De fato, nessa ordem de raciocínio, está perfeitamente correta a aplicação da responsabilidade solidária, até porque prevista no art. 1.518 do Código Civil de 1916 e repetida no art. 942 do Código em vigor, com a seguinte redação:

"Art. 942. Os bens do responsável pela ofensa ou violação do direito de outrem ficam sujeitos à reparação do dano causado; e se a ofensa tiver mais de uma autor, todos responderão solidariamente pela reparação.

Parágrafo único. São solidariamente responsáveis com os autores os co-autores e as pessoas designadas no art. 942."

Ocorre que a solidariedade decorre de haver mais de um causador de um mesmo dano. Em que pese tal fato, encontra-se inscrito na sentença o seguinte:

"Assim, ainda que existam diversas frações de áreas degradadas em que é perfeitamente possível definir-se ou determinar-se que chegaram ao estágio atual em razão direta da mineração específica levada a efeito pela empresa $\mathrm{X}$ ou $\mathrm{Y}$, tal como a extensão de solo de propriedade da respectiva mina, utilizada para mineração a céu aberto ou para depósito de rejeitos piritosos, a responsabilidade não deixa de ser solidária."

Aprofundando um pouco mais essa questão, observo que o Ministério Público ajuizou a ação contra vinte e seis pessoas, entre físicas e jurídicas de direito público e privado, ante a poluição perpetrada em sete municípios no Estado de Santa Catarina.

nexo causal entre o dano ocorrido em um determinado lugar por atividade poluidora realizada em outro local.

5. A desconsideração da pessoa jurídica consiste na possibilidade de se ignorar a personalidade jurídica autônoma da entidade moral para chamar à responsabilidade seus sócios ou administradores, quando utilizam-na com objetivos fraudulentos ou diversos daqueles para os quais foi constituída. Portanto, (i) na falta do elemento "abuso de direito"; (ii) não se constituindo a personalização social obstáculo ao cumprimento da obrigação de reparação ambiental; e (iii) nem comprovando-se que os sócios ou administradores têm maior poder de solvência que as sociedades, a aplicação da disregard doctrine não tem lugar e pode constituir, na última hipótese, obstáculo ao cumprimento da obrigação.

6. Segundo o que dispõe o art. $3^{\circ}$, IV, c/c o art. $14, \S 1^{\circ}$, da Lei n. 6.938/81, os sócios/administradores respondem pelo cumprimento da obrigação de reparação ambiental na qualidade de responsáveis em nome próprio. A responsabilidade será solidária com os entes administrados, na modalidade subsidiária.

7. A ação de reparação/recuperação ambiental é imprescritível.

8. Recursos de Companhia Siderúrgica Nacional, Carbonífera Criciúma S/A, Carbonífera Metropolitana S/A, Carbonífera Barro Branco S/A, Carbonífera Palermo Ltda., Ibramil - Ibracoque Mineração Ltda. não-conhecidos. Recurso da União provido em parte. Recursos de Coque Catarinense Ltda., Companhia Brasileira Carbonífera de Ararangua (massa falida), Companhia Carbonífera Catarinense, Companhia Carbonífera Urussanga providos em parte. Recurso do Ministério Público provido em parte. 
Assim é evidente que, num mesmo local de degradação ambiental, mais de uma mineradora foi responsável pela poluição, havendo entre elas, como afirmou-se na sentença, a responsabilidade solidária. Isso não quer dizer, todavia, que todas as mineradoras tenham poluído toda a área conjunta dos sete municípios.

Portanto, têm razão as mineradoras ao dizer que cada uma foi responsável pela degradação ambiental em partes específicas dos terrenos indicados pelo autor da ação. Daí terem sustentando a negativa de vigência do art. 1.518 do CC de 1916.

Buscam, ainda, indicar, por esse mesmo motivo, vulneração das disposições do $\S$ $1^{\circ}$ do art. 14 da Lei n. 6.938/81, sob alegação de que não existe nexo de causalidade entre a atividade poluidora de uma determinada mineradora, em local certo, com a poluição ocasionada em outra localidade. A esse respeito, encontrase doutrina de Magda Montenegro (in Meio Ambiente e Responsabilidade Civil, pág. 61), no seguinte sentido:

"É preciso atentar para o fato de que, se é possível a responsabilização solidária dos co-poluidores por um dano ambiental, não se pode olvidar a necessidade de se estabelecer, em relação a cada um deles, os pressupostos do dever de indenizar. Assim, não é porque uma região está degradada e nela existem várias empresas que se poderá, baseando-se apenas no critério geográfico, imputar a todas a responsabilidade civil pela degradação do meio ambiente. Imprescindível será a descrição objetiva das respectivas condutas e em que medida influíram para a materialização do dano, além, é claro, da própria especificação deste, cuja reparação é pleiteada, ainda que de forma genérica."

Portanto, havendo mais de um causador de um mesmo dano, devem responder solidariamente pela reparação ambiental. Todavia, se diversos forem os poluidores, mesmo que a poluição seja idêntica, mas perpetrada em lugares distintos e independentes, não há como atribuir-se a responsabilidade solidária, ante a falta de nexo causal entre o dano verificado em um determinado local e o poluidor de outro local, ressalvadas, por óbvio, as hipóteses de dano uno e indivisível, como se dá, v.g. na poluição dos recursos hídricos, subterrâneos e do ar.

Assim, tendo em vista a) a solidariedade, que torna possível a responsabilização do poluidor direto e do poluidor indireto, considerados co-autores que podem ter sua prestação exigida em conjunto ou individualmente, b) a responsabilidade objetiva, baseada na teoria do risco e c) a amplitude do conceito de poluidor em indireto, tem-se que, de acordo com a teoria do nexo causal adotada, poderá haver tanto soluções juridicamente razoáveis quanto soluções juridicamente injustas.

Como exemplo, temos a combinação da teoria do risco integral com a teoria da equivalência dos antecedentes causais. Por ela, todas as condições do delito seriam equivalentes, de modo que havendo pluralidade de causas, todas devem ser consideradas eficientes para a produção do dano. Assim, a série causal poderia ser transformada em uma cadeia sem fim na qual o próprio nascimento da pessoa poderia ser considerada causa para a existência de um dano ambiental que a própria pessoa possa ter 
provocado. Do mesmo modo, poderia ser considerado poluidor indireto, aquele que, lá atrás da cadeia, forneceu determinado equipamento para o complexo industrial, sem que tal maquinário tivesse apresentado defeitos e fosse o causador do dano.

Assim, a adoção de uma das facetas da teoria do risco e a escolha da teoria do nexo causal será de todo relevante para o estabelecimento de limites ao conceito de poluidor indireto.

Por ora, será realizada análise da jurisprudência e doutrina acerca da responsabilização de poluidores indiretos.

\subsection{A co-responsabilidade das instituições financeiras por danos ambientais.}

É inegável a existência de uma consciência geral, e que se torna cada vez mais ampla, acerca da necessidade de proteção ambiental. Neste sentido, a ampliação da responsabilidade socioambiental das instituições financeiras vem sendo mencionada como uma das resultantes de uma maior consciência tanto por parte dos consumidores quanto por parte das corporações.

Assim, a destinação do dinheiro que financia o consumo e a produção não deve prescindir de parâmetros éticos, ficando atrelado tanto à legalidade e quanto à moralidade de tal produção e de tal consumo. ${ }^{202}$

Por sua vez, deixa claro a Constituição Federal, em ser art. 192, caput, que o sistema financeiro nacional, estruturado de forma a promover o desenvolvimento equilibrado do País, deverá servir aos interesses da coletividade. Deste modo, tendo em vista que a poluição e a degradação ambiental ferem tanto a moralidade e a legalidade quanto os interesses da coletividade, não restam duvidas quanto a impossibilidade de o dinheiro publico financiar as atividades que causem lesão ao meio ambiente.

${ }^{202}$ LEME MACHADO, op. cit., p. 332. 
As instituições financeiras, conforme demonstrado a seguir, por força do legislador, passam a agir como espécie de controlador ambiental, devendo atuar em consonância com as exigências da legalidade ambiental e monitorar a boa utilização do dinheiro emprestado, sobretudo, quando aplicados em projetos que possam produzir danos ambientais.

Dispõe o legislador brasileiro, no art. 12 da Lei $n^{\circ}$. 6938/81, que

Art. 12. As entidades e órgãos de financiamento e incentivos governamentais condicionarão a aprovação de projetos habilitados a esses benefícios ao licenciamento, na forma desta Lei, e ao cumprimento das normas, dos critérios e dos padrões expedidos pelo CONAMA

No mesmo sentido, dispõe o Decreto 99247/90, o qual regulamentou a referida lei:

Art. 23. As entidades governamentais de financiamento ou gestoras de incentivos, condicionarão a sua concessão à comprovação do licenciamento previsto neste decreto.

Já o artigo 10 da Lei no . 6.938/81, prevê que

Art. 10 - A construção, instalação, ampliação e funcionamento de estabelecimentos e atividades utilizadoras de recursos ambientais, considerados efetiva e potencialmente poluidores, bem como os capazes, sob qualquer forma, de causar degradação ambiental, dependerão de prévio licenciamento de órgão estadual competente, integrante do Sistema Nacional do Meio Ambiente SISNAMA, e do Instituto Brasileiro do Meio Ambiente e Recursos Naturais Renováveis - IBAMA, em caráter supletivo, sem prejuízo de outras licenças exigíveis.

Certo é, portanto, que, tal qual previsão do parágrafo único do art. 12 da Lei $n^{\circ}$. 6938/81, o qual estabelece que as entidades e órgãos de financiamento e incentivos governamentais "deverão fazer constar dos projetos a realização de obras e aquisição de equipamentos destinados ao controle de degradação ambiental e à melhoria da qualidade do meio ambiente" ${ }^{203}$. Logo, tem-se que através da análise da proposta de credito, momento em que deve a instituição financeira verificar o cumprimento das exigências do Estudo de Impacto ambiental e/ou da Licença Ambiental, as

${ }^{203}$ Ibid. p. 338. 
instituições financeiras passam a atuar como meios de prevenção ao dano ao meio ambiente. ${ }^{204}$

Salienta-se ainda que, para que as instituições financiadoras possam dar "efetivo cumprimento às suas obrigações legais", devem as mesmas conhecer as competências dos órgãos ambientais, bem como avaliar, em casa caso concreto, "qual a licença ambiental a ser exigida de empreendimentos que pretendam se beneficiar de créditos e incentivos oficiais". Mister se faz o treinamento de equipes específicas dentro dos bancos treinadas para tanto. Tal exigência não se restringe apenas às instituições financeiras com personalidade jurídica de direito público, "mas a todos que recebem dinheiro público, ainda que com personalidade de direito privado". 205

Além disto, é imperioso ressaltar que a obrigação imposta às instituições financeiras não é restrita à exigência da licença ambiental, devendo as instituições verificar ainda o cumprimento das normas e critérios ambientais estabelecidos pelo CONAMA. ${ }^{206}$

Leme Machado leciona que

a alocação de recursos do financiador para o financiado, com a transgressão induvidosa da lei, coloca o financiador numa atividade de cooperação ou de coautoria com o financiado em todos os atos lesivos ambientais que ele fizer, por ação ou omissão ${ }^{207}$.

Assim, ainda que não dê diretamente ensejo ao dano ambiental, a Lei $n^{\circ} .6938 / 81$, em seu art. $3^{\circ}$, inciso IV, dispõe que poluidor é também aquele que indiretamente deu causa à lesão ao meio ambiente, prevendo ainda, em seu art. $14, \S 1^{\circ}$, a possibilidade de responsabilização de todos os transgressores tanto na esfera civil, quanto administrativa e criminal. Dentre as sanções previstas pela referida lei, expressamente há a possibilidade de

\footnotetext{
${ }^{204}$ Ibid. p. 338.

${ }^{205}$ SANTILLI, Juliana. A co-responsabilidade das instituições financeiras por danos ambientais e o licenciamento ambiental. Revista de Direito Ambiental, São Paulo, n. 21, 2001. p. 134.

${ }^{206}$ Ibid. p. 134 e 135.

${ }^{207}$ LEME MACHADO, op. cit., p. 338
} 
perda de benefícios e incentivos fiscais concedidos pelos órgãos financiadores, nos termos que seguem:

Art 14 - Sem prejuízo das penalidades definidas pela legislação federal, estadual e municipal, o não cumprimento das medidas necessárias à preservação ou correção dos inconvenientes e danos causados pela degradação da qualidade ambiental sujeitará os transgressores:

III - à perda ou suspensão de participação em linhas de financiamento em estabelecimentos oficiais de crédito;

Já a Lei $n^{\circ} .9 .605 / 98$, em seu art. $72^{\circ}, \S 8^{\circ}$, inciso IV, revogando de forma tácita o previsto no inciso IV do art. 14 da Lei $n^{\circ}$. 6.938/81, dentre as sanções restritivas de direitos, prevê a perda ou suspensão da participação em linhas de financiamento em estabelecimentos oficiais de crédito.

Deste modo, embora não expressamente definida pelas referidas leis, implícita está a responsabilidade dos bancos pela observância das normas protetivas ao meio ambiente sendo os mesmos responsáveis, ainda que indiretamente, pelo dano ambiental.

Tal qual o regime jurídico da responsabilidade em todos os eventos relacionados ao meio ambiente, a responsabilidade das instituições financeiras se dará de forma objetiva, tendo em vista o disposto no art. 14, $\S 1^{\circ}$, da referida lei. Deste modo, impossibilitada estará a instituição financeira de se eximir da "co-responsabilidade de se terem omitido, invocando ausência de imprudência, de negligencia, de imperícia ou de dolo". 208

Tem-se, portanto, conforme afirma Leme Machado, que "o nexo causal entre o ato, que provocou ou possa provocar o dano ambiental, no caso dos bancos, é presumido, por força do $\S 3^{\circ}$, do art. $2^{\circ}$ da Lei $n^{\circ}$. 8974/95". ${ }^{209}$. Esta, expressamente previu a co-responsabilidade dos bancos nos casos de financiamento de projetos de biotecnologia de modo que,

\footnotetext{
${ }^{208}$ Ibid. p. 338.

${ }^{209}$ Ibid. p. 338.
} 
aquele que financia, passa a ter a obrigação de averiguar se o financiamento está cumprindo a legislação ambiental.

A referida lei foi revogada pela Lei $\mathrm{n}^{\circ}$. 11.105/2005, a qual estabelece normas de segurança e mecanismos de fiscalização de atividades que envolvam organismos geneticamente modificados. Esta, assim como a lei por ela revogada, em seu art. $2^{\circ}, \S 4^{\circ}$ prevê que

Art. $2^{\mathrm{o}}$ As atividades e projetos que envolvam OGM e seus derivados, relacionados ao ensino com manipulação de organismos vivos, à pesquisa científica, ao desenvolvimento tecnológico e à produção industrial ficam restritos ao âmbito de entidades de direito público ou privado, que serão responsáveis pela obediência aos preceitos desta Lei e de sua regulamentação, bem como pelas eventuais conseqüências ou efeitos advindos de seu descumprimento.

$\S 4^{\circ}$ As organizações públicas e privadas, nacionais, estrangeiras ou internacionais, financiadoras ou patrocinadoras de atividades ou de projetos referidos no caput deste artigo devem exigir a apresentação de Certificado de Qualidade em Biossegurança, emitido pela CTNBio, sob pena de se tornarem co-responsáveis pelos eventuais efeitos decorrentes do descumprimento desta Lei ou de sua regulamentação.

\section{Tem-se, portanto,}

que na área da biotecnologia, a co-responsabilidade do financiador pelas conseqüências advindas de atividades e projetos por ele financiados é explicitamente estabelecida, não restando qualquer margem a duvida, sendo de se notar que é esta a tendência legislativa mais moderna: considerar que quem financia a degradação ambiental é co-responsável por ela. ${ }^{210}$

\subsection{Responsabilidade do Poder Público}

\section{De acordo com Mirra,}

se, por um lado, o Estado é o promotor por excelência da defesa do meio ambiente na sociedade, quando elabora e executa políticas públicas ambientais e quando exerce o controle e fiscalização das atividades potencialmente degradadoras do meio ambiente, por outro lado, ele aparece, também, em muitas circunstancias, como responsável direto e indireto pela degradação da qualidade ambiental, quando elabora e executa políticas públicas - como, por exemplo, as relacionadas ao desenvolvimento econômico e social, quando elabora e executa outras políticas públicas - e quando se omite no dever que tem de fiscalizar as

\footnotetext{
${ }^{210}$ SANTILLI, ob. cit., p. 138.
} 
atividades que causam danos ao meio ambiente e de adotar as medidas administrativas necessárias à preservação da qualidade ambiental. ${ }^{211}$

Dispõe o referido autor que questão intrincada e sujeita a controvérsias, é a possibilidade de a demanda ter sempre o Poder Público no pólo passivo, mesmo quando não for a Administração o responsável direto pelo dano ao meio ambiente. ${ }^{212}$

Fundamentado pelo dever de proteção ao meio ambiente imposto tanto ao particular quanto ao Poder Público pelo artigo 225 da Constituição Federal e tendo em vista o disposto no art. $3^{\circ}$, incido IV da Lei $n^{\circ} . .6938 / 81$, o qual torna possível que a pessoa jurídica de direito público seja considerada poluidor, é inegável a possibilidade de responsabilização do Estado, como poluidor direto ou, até mesmo indireto, pela ocorrência dos danos ambientais. ${ }^{213}$

Embora pacífico o entendimento de que é possível a responsabilização do Poder Público, Steigleder ${ }^{214}$ ressalva a existência de divergência doutrinária e jurisprudencial quanto à responsabilização objetiva do Estado em todas as circunstâncias. Responderia objetivamente o Estado em todas as hipóteses de condutas comissivas e omissivas da Administração ou apenas quando se trate de dano decorrente de ação de agentes Estatais?

Conforme expõe Lamac $^{215}$, quando se trata do Poder Público como poluidor direto, tendo o agente estatal praticado o ato, cabendo lembrar que o Poder Público por vezes exerce atividades iguais às dos particulares (petroquímica, siderúrgicas, etc.), a responsabilidade do Estado será sempre objetiva, com fulcro no art. $37, \S 6^{\circ}$ da Constituição Federal, sendo de rigor responsabilizar pessoalmente o agente que praticou tal ato. Contudo, neste último caso, a responsabilização deste ocorrerá regressivamente e apenas se

\footnotetext{
${ }^{211}$ MIRRA, Álvaro Luiz Valery. Proteção do meio ambiente: a omissão do poder público e o papel social do Judiciário no controle da administração pública. Revista de Direito Ambiental, São Paulo, n. 30, 2003. p. 35.

${ }^{212}$ Id. Ação..., op. cit., p. 216.

${ }^{213}$ BENJAMIN, op. cit., p. 37 e 38.

${ }^{214}$ STEIGLEDER, op. cit., p. 219.

${ }^{215}$ LAMAC, op. cit.,. p. 2271 e 2272.
} 
o ato tiver sido praticado com dolo ou culpa, cabendo falar em responsabilidade subjetiva do agente.

Assim, leciona Steigleder ${ }^{216}$ que, neste caso, em que o dano é provocado diretamente pelo Poder Público, por intermédio de seu agente estatal ou de concessionárias de serviços públicos, seria aplicável o art. 37 $\S 6^{\circ}$ da Constituição Federal, combinado com os arts. $3^{\circ}$, inciso IV e 14, $\S$ $1^{\text {o }}$, da Lei $n^{\circ}$. 6938/81. Deste modo, constatando-se o nexo causal direto entre o dano e a ação do agente ou da concessionária de serviço público, aplica-se a responsabilidade objetiva, fundada no risco administrativo ${ }^{217}$.

Para Leuzinger, em casos de danos provocados por ato comissivo de agentes públicos, cabe ao Estado repará-lo, ainda que esteja agindo licitamente, tendo em vista o princípio da repartição do ônus da atividade estatal pelos administrados. Por outro lado, quando a atividade causadora do dano for ilegal, incidirá ainda o princípio da legalidade. ${ }^{218}$

De acordo com os autores pesquisados, pode-se perceber que nesta hipótese de dano por ação, não há discordância doutrinária quando à responsabilização objetiva da administração ressaltando-se que, no caso de dano provocado por concessionária de serviço público, será estabelecida a solidariedade entre o poder concedente e a concessionária. ${ }^{219}$

Para Leuzinger ${ }^{220}$, nos casos em que o dano ambiental seja causado por pessoa jurídica, de direito privado ou público, distinta de entidade estatal, a responsabilidade do Estado, embora objetiva, será subsidiária à responsabilidade da entidade responsável pela prestação do serviço.

Steigleder menciona, ainda, outras duas hipóteses em que o Poder Público seria responsável pela reparação dos danos ambientais causados: a)

\footnotetext{
${ }^{216}$ STEIGLEDER, op. cit., p. 217.

${ }^{217}$ De acordo com Carvalho Filho, buscando seu fundamento na justiça social, "atenuando as dificuldades e impedimentos que o indivíduo teria que suportar quando prejudicado por condutas de agentes estatais", o Estado, sujeito jurídica, plítica e economicamente mais poderoso que o indivíduo, teria que arcar com os riscos naturais decorrentes de suas numerosas atividades. Surge então a "teoria do risco administrativo, como fundamento da responsabilidade objetiva do Estado". (CARVALHO FILHO, José dos Santos. Manual de direito Administrativo. $17^{\mathrm{a}}$ edição. Rio de Janeiro: Editora Lumen Juris , 2007. p. 475 e 476)

${ }^{218}$ LEUZINGER, op. cit., p. 192-193.

${ }^{219}$ STEIGLEDER, op. cit.,. p. 219.

${ }^{220}$ LEUZINGER, op. cit., p. 193.
} 
a responsabilidade comissiva por omissão, consubstanciada na omissão do Estado quanto à prestação de um serviço público quando teria o dever legal de prestá-lo, sendo tal omissão a causa adequada do dano e b) a responsabilidade por omissão do Poder Público quanto ao funcionamento de serviço público que se "consubstancia em deficiência do exercício do poder de polícia na físcalização das atividades poluidoras e na concessão de autorizações administrativas e licenças ambientais" 221.

No primeiro caso, em que há a responsabilidade comissiva por omissão, o Estado, embora possua o dever legal de prestar determinado serviço público, se omite, sendo tal omissão considerada a causa do prejuízo ambiental. Como exemplos, a autora apresenta os casos de destinação final de resíduos sólidos urbanos, o tratamento de esgotos e a conservação de rodovias ameaçadas de erosão.

Nestas circunstâncias, em que a omissão do Estado se refere à obrigação de sua incumbência especifica quanto à adoção de medidas e providencias indispensáveis à proteção de bens e recursos ambientais, caracterizando a recusa ao cumprimento de normas legais impositivas de condutas de caráter preservativo, a responsabilidade da Administração será direta vez que será sua omissão causa exclusiva ou primeira do dano verificado. $^{222}$

Diversos autores, dentre eles Pasqualotto ${ }^{223}$ e Leuzinger $^{224}$, manifestam-se, neste caso, pela responsabilização objetiva do Poder Público tendo em vista que a omissão estatal é causa principal e direta do dano ambiental.

Contudo, ressalva Steigleder ${ }^{225}$ que o Superior Tribunal de Justiça vem entendendo pela impossibilidade de intervenção do Poder Judiciário junto ao Poder Executivo para a determinação de execução de obras

\footnotetext{
${ }^{221}$ STEIGLEDER, op. cit., p. 220.

${ }^{222}$ MIRRA, Ação..., op. cit., p 219.

${ }^{223}$ PASQUALOTTO, op. cit.,. p.452.

${ }^{224}$ LEUZINGER, op. cit., p. 193.

${ }^{225}$ STEIGLEDER, op. cit.,. p. 223.
} 
específicas de saneamento ambiental, sob pena de se afetar a discricionariedade administrativa.

Neste sentido, já se pronunciou o Superior Tribunal de Justiça, através de sua $2^{\mathrm{a}}$ turma:

O Estado de Goiás edificou obra pública - um presídio - sem dotá-la de um sistema de esgoto sanitário adequado. Não podia fazê-la, e, se isso atenta contra o meio ambiente, a ação civil pública é a via própria para remover a causa dos danos causados. Sujeita também às leis, o Estado tem, nesse âmbito, as mesmas obrigações dos particulares. ${ }^{226}$

Não é outra a constatação de Mirra ${ }^{227}$, o qual demonstra que não são raros os julgados que entendem que a adoção de medidas administrativas de preservação de bens e recursos ambientais e de medidas que visam a implantação de políticas públicas ambientais é tarefa privativa do poder público o qual possuiria na discricionariedade, fundamentada na oportunidade e na conveniência, o subsídio para suas escolhas quanto à locação de seus recursos. Assim, estaria o Poder Judiciário proibido de interferir nestas opções inerentes à administração pública sob pena de violar o princípio constitucional de separação dos poderes.

Contudo, defende o autor que, na realidade, o que ocorre é o controle social sobre as omissões da Administração pela sociedade organizada, ainda que por intermédio do Poder Judiciário, não cabendo falar em ingerência de um poder sobre o outro. Portanto, defende que não há como não se admitir o controle jurisdicional da Administração, para que se vença a inércia do poder público na adoção de medidas de preservação da qualidade ambiental.

Steigleder também defende a mesma posição sob o fundamento de que o Judiciário nestas condições, apenas visa suprimir uma omissão da Administração através da exigência do cumprimento de obrigações públicas

\footnotetext{
${ }^{226}$ STJ, Recurso Especial 88776/GO, Segunda Turma, Rel. Ministro Ari Pargendler, julgado em 19/05/1997, DJ 09.06.1997 p. 25501. Consta da ementa que: "PROCESSO CIVIL. AÇÃO CIVIL PÚBLICA. DANOS AO MEIO AI4BIENTE CAUSADO PELO ESTADO. Se o Estado edifica obra pública - no caso, um presídio - sem dotá-la de um sistema de esgoto sanitário adequado, causando prejuízos ao meio ambiente, a ação civil pública é, sim, a via prápria para obrigá-lo às construções necessárias à eliminaçào dos danos; sujeito também às leis, o Estado tem, nesse âmbito, as mesmas responsabilidades dos particulares. Recurso especial conhecido e provido."

${ }^{227}$ MIRRA, Proteção..., op.cit., p. 36 a 41.
} 
já previstas na legislação, sendo cabível, portanto a ingerência do Poder

Judiciário no Poder Público, garantindo assim à proteção ambiental. ${ }^{228}$

Em 2004, no que diz respeito à coleta de lixo, serviço essencial à saúde pública, acompanhando o entendimentos destes autores, decidiu o STJ que

A determinação judicial desse dever pelo Estado, não encerra suposta ingerência do judiciário na esfera da administração. Deveras, não há discricionariedade do administrador frente aos direitos consagrados, quiçá constitucionalmente. Nesse campo a atividade é vinculada sem admissão de qualquer exegese que vise afastar a garantia pétrea. ${ }^{229}$

${ }^{228}$ STEIGLEDER, op. cit., p. 224.
${ }^{229}$ STJ, Primeira Turma, REsp 575998 / MG, Min Rel. Luiz Fux, julgado em 07/10/2004, v.u., DJ
16.11.2004 p. 191. Consta na ementa: PROCESSUAL CIVIL E ADMINISTRATIVO. COLETA
DE LIXO. SERVIÇO ESSENCIAL. PRESTAÇÃO DESCONTINUADA. PREJUÍZO À SAÚDE
PÚBLICA. DIREITO FUNDAMENTAL. NORMA DE NATUREZA PROGRAMÁTICA.
AUTO-EXECUTORIEDADE. PROTEÇÃO POR VIA DA AÇÃO CIVIL PÚBLICA.
POSSIBILIDADE. ESFERA DE DISCRICIONARIEDADE DO ADMINISTRADOR.
INGEREENCIA DO PODER JUDICIÁRIO.

1. Resta estreme de dúvidas que a coleta de lixo constitui serviço essencial, imprescindível à manutenção da saúde pública, o que o torna submisso à regra da continuidade. Sua interrupção, ou ainda, a sua prestação de forma descontinuada, extrapola os limites da legalidade e afronta a cláusula pétrea de respeito à dignidade humana, porquanto o cidadão necessita utilizar-se desse serviço público, indispensável à sua vida em comunidade.

2. Releva notar que uma Constituição Federal é fruto da vontade política nacional, erigida mediante consulta das expectativas e das possibilidades do que se vai consagrar, por isso cogentes e eficazes suas promessas, sob pena de restarem vãs e frias enquanto letras mortas no papel. Ressoa inconcebível que direitos consagrados em normas menores como Circulares, Portarias, Medidas Provisórias, Leis Ordinárias tenham eficácia imediata e os direitos consagrados constitucionalmente, inspirados nos mais altos valores éticos e morais da nação sejam relegados a segundo plano. Trata-se de direito com normatividade mais do que suficiente, porquanto se define pelo dever, indicando o sujeito passivo, in casu, o Estado.

3. Em função do princípio da inafastabilidade consagrado constitucionalmente, a todo direito corresponde uma ação que o assegura, sendo certo que todos os cidadãos residentes em Cambuquira encartam-se na esfera desse direito, por isso a homogeneidade e transindividualidade do mesmo a ensejar a bem manejada ação civil pública.

4. A determinação judicial desse dever pelo Estado, não encerra suposta ingerência do judiciário na esfera da administração. Deveras, não há discricionariedade do administrador frente aos direitos consagrados, quiçá constitucionalmente. Nesse campo a atividade é vinculada sem admissão de qualquer exegese que vise afastar a garantia pétrea.

5. Um país cujo preâmbulo constitucional promete a disseminação das desigualdades e a proteção à dignidade humana, alçadas ao mesmo patamar da defesa da Federação e da República, não pode relegar a saúde pública a um plano diverso daquele que o coloca, como uma das mais belas e justas garantias constitucionais.

6. Afastada a tese descabida da discricionariedade, a única dúvida que se poderia suscitar resvalaria na natureza da norma ora sob enfoque, se programática ou definidora de direitos.

7. As meras diretrizes traçadas pelas políticas públicas não são ainda direitos senão promessas de lege ferenda, encartando-se na esfera insindicável pelo Poder Judiciário, qual a da oportunidade de sua implementação.

8. Diversa é a hipótese segundo a qual a Constituição Federal consagra um direito e a norma infraconstitucional o explicita, impondo-se ao judiciário torná-lo realidade, ainda que para isso, resulte obrigação de fazer, com repercussão na esfera orçamentária.

9. Ressoa evidente que toda imposição jurisdicional à Fazenda Pública implica em dispêndio e atuar, sem que isso infrinja a harmonia dos poderes, porquanto no regime democrático e no estado de direito o Estado soberano submete-se à própria justiça que instituiu. Afastada, assim, a 
Na segunda hipótese, tratando-se se omissão da Administração Pública pela deficiência do exercício do poder de polícia na fiscalização das atividades poluidoras e na concessão de licenças e autorizações administrativas, há divergência quando a responsabilização objetiva ou subjetiva do Estado.

Neste caso, o que há é um dano decorrente indiretamente da omissão do Estado vez que inexiste nexo de causalidade direto entre o prejuízo ambiental e a atividade estatal. Na verdade, como causa principal da degradação ambiental tem-se a atividade clandestina ou lícita ${ }^{230}$ do particular, tendo em vista, no último caso, a concessão de uma autorização ou licença ambiental irregular ou deficiente, sendo o particular (e não o Estado) o responsável direto pelo dano ambiental.

Convém observar a posição de Edis Milaré, o qual sustenta que o Poder Público sempre poderá figurar no pólo passivo de qualquer demanda dirigida à reparação do meio ambiente, ora por ser o responsável por ter ocasionado diretamente o dano, por intermédio de um de seus agentes, ora por ser, ao menos, solidariamente responsável, tendo em vista sua omissão no dever de fiscalizar e impedir que tais danos aconteçam. A propósito, vale lembrar que a Constituição Federal impôs ao Poder Público o dever de preservar e defender o meio ambiente para as presentes e futuras gerações. Ao Estado restará, no entanto, voltar-se regressivamente, no último caso, contra o direto causador do dano e, naquele outro, contra o agente que, por

ingerência entre os poderes, o judiciário, alegado o malferimento da lei, nada mais fez do que cumpri-la ao determinar a realização prática da promessa constitucional.

10. "A questão do lixo é prioritária, porque está em jogo a saúde pública e o meio ambiente." Ademais, "A coleta do lixo e a limpeza dos logradouros públicos são classificados como serviços públicos essenciais e necessários para a sobrevivência do grupo social e do próprio Estado, porque visam a atender as necessidades inadiáveis da comunidade, conforme estabelecem os arts. 10 e 11 da Lei n. ${ }^{\circ} .783 / 89$. Por tais razões, os serviços públicos desta natureza são regidos pelo PRINCÍPIO DA CONTINUIDADE."

11. Recurso especial provido.

${ }^{230}$ Cabe ressaltar que, de acordo com Machado, não há liberação do empreendedor quanto à reparação de um dano ambiental tendo em vista a concessão, pelo poder público, da licença ambiental. Esta apenas retira o caráter de ilicitude administrativa do ato, não afastando, contudo, a responsabilidade civil de reparação do dano ambiental. A única prerrogativa que possui o empreendedor licenciado será à impossibilidade de a Administração Pública sancionar o prejuízo ambiental, subsistindo, todavia, a possibilidade de responsabilização civil. (LEME MACHADO, op. cit., p. 362 e 363 ) 
culpa, deu causa à danosidade ambiental. Por outro lado, ressalta o autor que, na prática, para não se penalizar a sociedade, a qual é, na realidade, quem paga as contas públicas, é conveniente só acionar o Estado quando este for diretamente o causador do dano. Nas demais hipóteses, segundo a regra da solidariedade, sendo possível escolher um opção, será conveniente que se opte, primeiramente, por acionar aquele que lucra com a atividade causadora do dano. ${ }^{231}$

Apesar do exposto, grande parte da doutrina, como Mirra ${ }^{232}$, Steigleder $^{233}$, Mello $^{234}$, Leuzinger ${ }^{235}$, dentre outros, demonstra objeções a se acionar, com base no princípio da solidariedade, indiscriminadamente o Estado, como poluidor indireto, pelos danos causados diretamente por terceiros.

Para Mirra, tornar legítimo o Estado para figurar no pólo passivo de uma demanda ambiental de forma indiscriminada, tendo em vista a sua omissão em impedir e fiscalizar a ocorrência de um dano ambiental, seria o mesmo que transferir à sociedade, vítima da degradação, a responsabilidade pelos prejuízos, com todo o ônus decorrente. Na realidade, de acordo com o autor, deveria haver a individualização do principal responsável evitando-se assim a socialização dos encargos oriundos da reparação dos danos provocados por particulares. ${ }^{236}$

De acordo com Mello ${ }^{237}$, quando ocorre um dano pela omissão do Estado, nas situações de falta do serviço público (quando o serviço não funciona, funciona tardiamente ou mal), deve-se aplicar a teoria da responsabilidade subjetiva (e não a objetiva como nos demais casos), embora seja possível se partir de uma presunção juris tantum de responsabilidade. Isto porque, pela inação do Estado só cabe responsabilizá-

\footnotetext{
${ }^{231}$ MILARÉ, Edis, op. cit., p. 909 e 910.

${ }^{232}$ MIRRA, Proteção..., op. cit., p. 7.

${ }^{233}$ STEIGLEDER, op. cit., p. 221.

${ }^{234}$ MELLO, Celso Antônio Bandeira de. Curso de Direito Administrativo. $18^{\text {a }}$ edição. São Paulo: Malheiros Editores, 2005 p. 936 e 937

${ }^{235}$ LEUZINGER, op. cit., p. 193.

${ }^{236}$ MIRRA, Proteção..., op. cit., p. 7.

${ }^{237}$ MELLO, op. cit., p. 936 e 937.
} 
lo caso haja o descumprimento de um dever legal de impedir a ocorrência do dano. Assim, havendo responsabilidade por ilícito, o Estado apenas responde caso sua conduta ilícita seja proveniente de impudência, negligencia, imperícia ou dolo não havendo que se falar, nestes casos, em responsabilidade objetiva, mas, sim, em responsabilidade subjetiva do Estado.

Carvalho Filho, por sua vez, sustenta a mesma posição:

quer nos parecer assim que o Estado se sujeita à responsabilidade objetiva, mas, quando se tratar de conduta omissiva, estará ele na posição comum de todos, vale dizer, rua responsabilização se dará por culpa. ${ }^{238}$

Steigleder ${ }^{239}$ afirma ainda que, tendo em vista a inexistência de nexo de causalidade direto entre a atividade Estatal e o dano ambiental vez que a lesão ou resultou de atividade clandestina do particular ou de atividade lícita "empreendida em virtude de uma autorização administrativa ou licenciamento ambiental irregular ou deficiente", tem-se a hipótese de responsabilidade indireta da Administração. Assim, pelo dano decorrente de omissão, deve-se demonstrar que o Estado ou omitiu-se ilicitamente ou que se comportou inferiormente ao padrão legal exigível, o qual varia caso a caso, não tendo impedido a ocorrência do dano.

Ademais, Mirra considera que

no que se refere à omissão da Administração no efetivo poder de polícia ambiental, como discriminado por Helli Alves de Oliveira, somente no caso de culpa grave, ou seja, de omissão injustificável das autoridades, é que se deveria admitir a responsabilização solidária do Estado pelos danos ambientais provenientes de atos praticados por terceiros. ${ }^{240}$

Deste modo, conforme afirma Mukai ${ }^{241}$, no caso de ações voluntárias de particulares, empreendidas de forma clandestina, em casos de omissão da Administração, aplica-se a tese de responsabilidade subjetiva, por culpa grave. Assim, a responsabilização do Poder Público dependerá de fatos comprobatórios de que o Estado, embora tenha tomando conhecimento da

\footnotetext{
${ }^{238}$ CARVALHO FILHO, op. cit., p. 489 e 490.

${ }^{239}$ STEIGLEDER, op. cit., p. 221.

${ }^{240}$ MIRRA, Ação..., p. 217.

${ }^{241}$ MUKAI, op. cit., p. 77.
} 
iminência do dano, não tomou as providencias necessárias para que o prejuízo ambiental não ocorresse.

Neste caso, também solidariamente e por omissão, na modalidade falta de serviço, a Administração quando houver falta de fiscalização dentro dos padrões normais de atuação. ${ }^{242}$

Por outro lado, há que se ressalvar, todavia, que "se o dano ao meio ambiente se deu por ato particular, à socapa da vigilância e fiscalização da Administração, a responsabilidade solidária inexistirá”. ${ }^{243}$

$\mathrm{Na}$ hipótese de danos causados por atividades licenciadas ou autorizadas ilegalmente pela Administração, incidindo, assim a responsabilidade por ato ilícito, a qual caracteriza a culpa na prestação do serviço, entendem estes autores, ser o Estado responsável solidário, no mínimo de forma indireta, com o degradador direto, cabendo salientar que, nestes casos deverá se perquirir a culpa (latu sensu) da Administração Pública. ${ }^{244}$

Leuzinger $^{245}$ e Mirra $^{246}$ ressaltam ainda que, caso a licença ou autorização ambientais sejam legais e houver fiscalização dentro dos padrões exigíveis, não caberá falar em responsabilidade do Poder Público, sendo a mesma exclusiva do particular. Contudo, Mirra ressalva a possibilidade de se responsabilizar o Estado, caso o ato administrativo seja legal e tenha o particular se afastado das diretrizes traçadas pelo órgão público. Neste caso, a responsabilização não terá como fundamento a outorga da licença, mas, sim, a ausência de fiscalização adequada, hipótese já analisada e pela qual incidirá a responsabilidade subjetiva da Administração.

Para Mukai, nas hipóteses em que o ato administrativo que autoriza ou licencia determinada atividade é lícito e, embora o particular não se desvie do estabelecido pelo Poder Público, ocorre o dano, deverá a

\footnotetext{
${ }^{242}$ LEUZINGER, op. cit., p. 194.

${ }^{243}$ MUKAI, op. cit., p. 77.

${ }^{244}$ LEUZINGER, op. cit., p. 194.

${ }^{245}$ Ibid. p. 194.

${ }^{246}$ MIRRA, Ação..., p. 221.
} 
Administração suportá-los com base na responsabilidade objetiva ou do risco. $^{247}$

Por sua vez, Lamac ${ }^{248}$ entende que nos casos de atos licenciamento de obras ou atividades, tendo em vista a conduta comissiva do Estado (e não omissiva conforme entendem os demais autores), responderá o Poder Publico objetivamente, com fulcro no art. $37 \S 6^{\circ}$ da Constituição Federal de 1988, bastando apenas, para que se configure a responsabilidade, a demonstração do nexo de causalidade e do dano.

Quanto aos casos fortuitos ou força maior, entendem Steigleder ${ }^{249}$ e Lamac $^{250}$, apenas poder ser o Erário responsável por lesões ambientais ocorridas caso o evento danoso tenha sido previsível e o Estado nada tivesse feito para impedi-lo. Caberia então, neste caso, a responsabilização subjetiva da Administração por não ter obstado o dano enquanto deveria fazê-lo.

Todavia, adverte Mirra que tal orientação no sentido de aplicar a responsabilidade subjetiva em alguns casos parece ir de encontro ao disposto nos arts. $3^{\circ}$, inciso IV e $14, \S 1^{\circ}$ da Lei $\mathrm{n}^{\mathrm{o}}$. 6938/81 e ao disposto no art. 225, $\$ 3^{\circ}$, da Constituição Federal de 88, os quais estabelecem a responsabilização objetiva do Estado em casos de condutas e atividades lesivas ao meio ambiente. Não fazendo distinção entre condutas comissivas ou omissivas. ${ }^{251}$

Neste sentido, em 2005, decidiu a Segunda Turma do Superior Tribunal de Justiça:

Por fim, o art. $14 \S \mathbf{1}^{\circ}$, objeto deste recurso especial indica: I) as penalidades que o transgressor poderá estar sujeito pelo descumprimento das medidas necessárias à preservação do meio ambiente, dentre elas a perda de incentivos fiscais e linhas de financiamento e suspensão de sua atividade, e II) a natureza objetiva da responsabilidade pelo dano causado ao meio ambiente.

"Art. 14 - Sem prejuízo das penalidades definidas pela legislação federal, estadual e municipal, o não cumprimento das medidas necessárias à

\footnotetext{
${ }^{247}$ MUKAI, op. cit., p. 73.

${ }^{248}$ LAMAC, op. cit., p. 2271 e 2272.

${ }^{249}$ STEIGLEDER, op. cit., p. 223.

${ }^{250}$ LAMAC, op. cit., p. 2283.

${ }^{251}$ MIRRA, Ação..., op. cit., p. 217.
} 
preservação ou correção dos inconvenientes e danos causados pela degradação da qualidade ambiental sujeitará os transgressores:

(...)

II - à perda ou restrição de incentivos e benefícios fiscais concedidos pelo Poder Público;

III - à perda ou suspensão de participação em linhas de financiamento em estabelecimentos oficiais de crédito;

IV - à suspensão de sua atividade.

$\S 1^{\circ}$ Sem obstar a aplicação das penalidades previstas neste artigo, é o poluidor obrigado, independentemente da existência de culpa, a indenizar ou reparar os danos causados ao meio ambiente e a terceiros, afetados por sua atividade. O Ministério Público da União e dos Estados terá legitimidade para propor ação de responsabilidade civil e criminal, por danos causados ao meio ambiente.

(...)".

Assim, independentemente da existência de culpa, o poluidor, ainda que indireto (Estado-recorrente) (art. 3 da Lei $\mathrm{n}^{\circ}$. 6.938/81), é obrigado a indenizar e reparar o dano causado ao meio ambiente.

Conclusão: O repasse das verbas pelo Estado do Paraná ao Município de Foz de Iguaçu (ação), a ausência das cautelas fiscalizatórias no que se refere às licenças concedidas e as que deveriam ter sido confeccionadas pelo ente estatal (omissão), concorreram para a produção do dano ambiental. Tais circunstâncias, pois, são aptas a caracterizar o nexo de causalidade do evento, e assim, legitimar a responsabilização objetiva do recorrente. ${ }^{252}$

252 STJ, Segunda Turma, Recurso Especial 604.725/PR, Min. Rel. Castro Meira, j. 21/06/2005, v.u., DJ 22.08.2005 p. 202. Consta na ementa: “AÇÃO CIVIL PÚBLICA. DANO CAUSADO AO MEIO AMBIENTE. LEGITIMIDADE PASSIVA DO ENTE ESTATAL. RESPONSABILIDADE OBJETIVA. RESPONSÁVEL DIRETO E INDIRETO. SOLIDARIEDADE. LITISCONSÓRCIO FACULTATIVO. ART.267, IV DO CPC. PREQUESTIONAMENTO. AUSÊNCIA. SÚMULAS 282 E 356 DO STF.

1. Ao compulsar os autos verifica-se que o Tribunal a quo não emitiu juízo de valor à luz do art. 267 IV do Código de Ritos, e o recorrente sequer aviou embargos de declaração com o fim de prequestioná-lo. Tal circunstância atrai a aplicação das Súmulas nº 282 e 356 do STF.

2. O art. 23, inc. VI da Constituição da República fixa a competência comum para a União, Estados, Distrito Federal e Municípios no que se refere à proteção do meio ambiente e combate à poluição em qualquer de suas formas. No mesmo texto, o art. 225, caput, prevê o direito de todos a um meio ambiente ecologicamente equilibrado e impõe ao Poder Público e à coletividade o dever de defendê-lo e preservá-lo para as presentes e futuras gerações.

3. O Estado recorrente tem o dever de preservar e fiscalizar a preservação do meio ambiente. $\mathrm{Na}$ hipótese, o Estado, no seu dever de fiscalização, deveria ter requerido o Estudo de Impacto Ambiental e seu respectivo relatório, bem como a realização de audiências públicas acerca do tema, ou até mesmo a paralisação da obra que causou o dano ambiental.

4. O repasse das verbas pelo Estado do Paraná ao Município de Foz de Iguaçu (ação), a ausência das cautelas fiscalizatórias no que se refere às licenças concedidas e as que deveriam ter sido confeccionadas pelo ente estatal (omissão), concorreram para a produção do dano ambiental. Tais circunstâncias, pois, são aptas a caracterizar o nexo de causalidade do evento, e assim, legitimar a responsabilização objetiva do recorrente.

5. Assim, independentemente da existência de culpa, o poluidor, ainda que indireto (Estadorecorrente) (art. $3^{\circ}$ da Lei $\mathrm{n}^{\circ}$ 6.938/81), é obrigado a indenizar e reparar o dano causado ao meio ambiente (responsabilidade objetiva).

6. Fixada a legitimidade passiva do ente recorrente, eis que preenchidos os requisitos para a configuração da responsabilidade civil (ação ou omissão, nexo de causalidade e dano), ressalta-se, também, que tal responsabilidade (objetiva) é solidária, o que legitima a inclusão das três esferas de poder no pólo passivo na demanda, conforme realizado pelo Ministério Público (litisconsórcio facultativo).

7. Recurso especial conhecido em parte e improvido." 
Percebe-se, assim, que o STJ adotou a teoria da responsabilidade objetiva tanto para a conduta comissiva do Estado, qual seja o repasse de verbas para o Município de Foz do Iguaçu, quanto para a conduta omissiva do mesmo, caracterizada pela ausência de cautela fiscalizatória no que se refere às licenças ambientais concedidas.

Em que pese o saber ilibado dos Ministros do STJ, tomando por base os ensinamentos de Álvaro Mirra, tem-se que tal decisão restou equivocada. Primeiramente, pelo fato de se considerar o mero incentivo governamental para o desempenho da atividade, como conduta comissiva passível de ensejar a responsabilização objetiva do Estado. Para Mirra,

"o mero incentivo ou estímulo governamental para o desempenho de atividades que na prática se revelam degradadoras, devido ao modo do seu exercício pelo empreendedor, seria insuficiente para firmar, mesmo em tese, tal responsabilidade, por não implicar, por si só, em tolerância, conivência ou cumplicidade do Poder Público com o dano ambiental eventualmente causado." 253

Ademais, por todo o exposto, no entendimento de Mirra, Mello, Steigleder, Carvalho filho, dentre outros, a omissão da Administração quanto ao exercício do poder de polícia ensejaria a responsabilização subjetiva da administração por culpa grave.

Deste modo, o Poder Público apenas poderia ser responsabilizado no caso em questão pela omissão quanto à fiscalização e, ainda assim, caso tenha agido com culpa ou dolo.

Já em 2007, em sede de recurso especial, a mesma Segunda Turma decide de forma diversa, acordando, por unanimidade, com o voto do Ministro Relator João Otávio de Noronha para responsabilizar, desta vez subjetivamente, pela ineficiência do serviço fiscalizatório, a União. Do acórdão, extraem-se os seguintes trechos:

“A União também buscou defender que não tem responsabilidade solidária com as empresas mineradoras à cominação imposta de recuperação do meio ambiente e indenizações conseqüentes. Aduz, principalmente, que a responsabilidade deve ser infligida apenas aos entes poluidores, ante o que estabelece o princípio do

${ }^{253}$ MIRRA, Ação..., op. cit., p. 220. 
"poluidor- pagador". Sustentou, ainda que, se obrigada à reparação, na verdade estar-se-á compelindo a sociedade à auto-indenização.

A primeira questão que se coloca é afeta ao campo da responsabilidade civil do Estado por omissão, e, em casos tais, entendo, assim como grande parte da doutrina e jurisprudência, que a responsabilidade é subjetiva, uma vez que a ilicitude no comportamento omissivo é aferido sob a perspectiva de que deveria o Estado ter agido por imposição legal.

Com relação a esse fato (omissão ou não do ente público), encontra-se no acórdão recorrido a conclusão de que a União foi omissa no dever de fiscalização, permitindo às mineradoras o exercício de suas atividades extrativas sem nenhum controle ambiental.

(...)

A obrigação legal de administração, fiscalização e controle sobre as atividades extrativas minerais imposta à União encontra-se nas seguintes normas infraconstitucionais:

(...)

Cumpre, então, observar que, se a lei impõe ao Poder Público o controle e fiscalização da atividade mineradora, possibilitando a aplicação de penalidades, não lhe compete optar por não fazê-lo, porquanto inexiste discricionariedade, mas obrigatoriedade de cumprimento de conduta impositiva.

A propósito, cito doutrina de Celso Antonio Bandeira de Mello:

"Não bastará, então, para configurar-se responsabilidade estatal, a simples relação entre ausência do serviço (omissão estatal) e o dano sofrido. Com efeito: inexistindo obrigação legal de impedir um certo evento danoso (obrigação, de resto, só cogitável quando haja possibilidade de impedi-lo mediante atuação diligente), seria um verdadeiro absurdo imputar ao Estado responsabilidade por um dano que não causou, pois isto equivaleria a extraí-la do nada; significaria pretender instaurá-la prescindindo de qualquer fundamento racional ou jurídico. Cumpre que haja algo mais: a culpa por negligência, imprudência ou imperícia no serviço, ensejadoras do dano, ou então o dolo, intenção de omitir-se, quando era obrigatório para o Estado atuar e fazê-lo segundo um certo padrão de eficiência capaz de obstar ao evento lesivo. Em uma palavra: é necessário que o Estado haja incorrido em ilicitude, por não ter acorrido para impedir o dano ou por haver sido insuficiente neste mister, em razão de comportamento inferior ao padrão legal exigível" (sem destaque no original).

Assim, irrefutável o acórdão quanto à condenação da União (...)". ${ }^{254}$

${ }^{254}$ STJ, Segunda Turma, REsp 647.493-SC , Rel. Min. João Otávio de Noronha, j. 22/05/2007, v.u., DJ 22/10/2007. Dispõe a ementa que: "RECURSO ESPECIAL. AÇ̃̃O CIVIL PÚBLICA. POLUIÇÃO AMBIENTAL. EMPRESAS MINERADORAS. CARVÃO MINERAL. ESTADO DE SANTA CATARINA. REPARAÇÃO. RESPONSABILIDADE DO ESTADO POR OMISSÃO. RESPONSABILIDADE SOLIDÁRIA. RESPONSABILIDADE SUBSIDIÁRIA.

1. A responsabilidade civil do Estado por omissão é subjetiva, mesmo em se tratando de responsabilidade por dano ao meio ambiente, uma vez que a ilicitude no comportamento omissivo é aferida sob a perspectiva de que deveria o Estado ter agido conforme estabelece a lei.

2. A União tem o dever de fiscalizar as atividades concernentes à extração mineral, de forma que elas sejam equalizadas à conservação ambiental. Esta obrigatoriedade foi alçada à categoria constitucional, encontrando-se inscrita no artigo $225, \S \S 1^{\circ}, 2^{\circ}$ e $3^{\circ}$ da Carta Magna.

3. Condenada a União a reparação de danos ambientais, é certo que a sociedade mediatamente estará arcando com os custos de tal reparação, como se fora auto-indenização. Esse desiderato apresenta-se consentâneo com o princípio da eqüidade, uma vez que a atividade industrial responsável pela degradação ambiental - por gerar divisas para o país e contribuir com percentual significativo de geração de energia, como ocorre com a atividade extrativa mineral - a toda a sociedade beneficia. 
No mesmo sentido, decide a Primeira Turma do STJ: "a responsabilidade do Estado, em se tratando de fiscalização, é subjetiva, dependendo da verificação de culpa". ${ }^{255}$

Por fim, em último caso, quando impossível for a identificação do responsável pela degradação, tendo em vista a impossibilidade de se provar

4. Havendo mais de um causador de um mesmo dano ambiental, todos respondem solidariamente pela reparação, na forma do art. 942 do Código Civil. De outro lado, se diversos forem os causadores da degradação ocorrida em diferentes locais, ainda que contíguos, não há como atribuir-se a responsabilidade solidária adotando-se apenas o critério geográfico, por falta de nexo causal entre o dano ocorrido em um determinado lugar por atividade poluidora realizada em outro local.

5. A desconsideração da pessoa jurídica consiste na possibilidade de se ignorar a personalidade jurídica autônoma da entidade moral para chamar à responsabilidade seus sócios ou administradores, quando utilizam-na com objetivos fraudulentos ou diversos daqueles para os quais foi constituída. Portanto, (i) na falta do elemento "abuso de direito"; (ii) não se constituindo a personalização social obstáculo ao cumprimento da obrigação de reparação ambiental; e (iii) nem comprovando-se que os sócios ou administradores têm maior poder de solvência que as sociedades, a aplicação da disregard doctrine não tem lugar e pode constituir, na última hipótese, obstáculo ao cumprimento da obrigação.

6. Segundo o que dispõe o art. $3^{\circ}$, IV, c/c o art. $14, \S 1^{\circ}$, da Lei n. 6.938/81, os sócios/administradores respondem pelo cumprimento da obrigação de reparação ambiental na qualidade de responsáveis em nome próprio. A responsabilidade será solidária com os entes administrados, na modalidade subsidiária.

7. A ação de reparação/recuperação ambiental é imprescritível.

8. Recursos de Companhia Siderúrgica Nacional, Carbonífera Criciúma S/A, Carbonífera Metropolitana S/A, Carbonífera Barro Branco S/A, Carbonífera Palermo Ltda., Ibramil - Ibracoque Mineração Ltda. não-conhecidos. Recurso da União provido em parte. Recursos de Coque Catarinense Ltda., Companhia Brasileira Carbonífera de Ararangua (massa falida), Companhia Carbonífera Catarinense, Companhia Carbonífera Urussanga providos em parte. Recurso do Ministério Público provido em parte.

${ }^{255}$ STJ. Primeira Turma, AgRg no Ag 822764 / MG, Min. Rel. José Delgado, j. 05/06/2007, v.u., DJ 02.08.2007 p. 364. Consta na ementa: PROCESSUAL CIVIL. AGRAVO REGIMENTAL. AGRAVO DE INSTRUMENTO. AMBIENTAL. LEGITIMIDADE DO ESTADO DE MINAS GERAIS. OMISSÃO DO DEVER DE FISCALIZAR. PRECEDENTES.

1. Cuida-se de agravo regimental interposto pelo Estado de Minas Gerais contra decisão que entendeu: a) inexistir ofensa ao artigo 535 do CPC; b) não ter sido a divergência jurisprudencial demonstrada conforme os ditames do CPC e do RISTJ; c) harmonizar-se o entendimento do acórdão recorrido com a jurisprudência deste STJ. Sustenta a agravante, em síntese, que: a) embora tenham sido apresentados embargos declaratórios, o Tribunal a quo não analisou questão relevante pertinente à responsabilidade objetiva do poluidor (art. $14, \S 1^{\circ}$, da Lei n. 6.930/81) e subjetiva da Administração Pública; b) a doutrina e a jurisprudência são favoráveis à sua tese; c) a responsabilidade do Estado, em se tratando de fiscalização, é subjetiva, dependendo da verificação de culpa; d) o dissídio pretoriano foi devidamente comprovado.

2. A matéria central sobre a responsabilidade objetiva do poluidor, presente no art. $14, \S 1^{\circ}$, da Lei n. 6.930/81, e subjetiva da Administração Pública, foi analisada no acórdão vergastado. Não há de se falar em violação do art. 535, II, do CPC.

3. A conclusão do acórdão exarado pelo Tribunal de origem está em consonância com a jurisprudência deste Superior Tribunal de Justiça que se orienta no sentido de reconhecer a legitimidade passiva de pessoa jurídica de direito público para responder por danos causados ao meio ambiente em decorrência da sua conduta omissiva quanto ao dever de fiscalizar. Aplicável, portanto, a Súmula 83/STJ.

4. Agravo regimental não-provido. 
o nexo de causalidade ou, até mesmo, por se tratar de empresa liquidada ou insolvente e, não sendo possível a responsabilização do Poder Público por sua omissão quanto ao exercício efetivo do poder de polícia, haverá que se recorrer ao Fundo de Reparação de Bens Lesados, previsto no art. 13 da Lei $\mathrm{n}^{\mathrm{o}} .7347 / 85$ ao qual, todavia, subsistirá o direito de regresso. ${ }^{256}$

\subsection{A responsabilidade da agroindústria diante do dano ambiental originado no âmbito da propriedade do produtor integrado}

De acordo com Lauschner, o complexo agroindustrial corresponde ao

(...) total das operações que abrangem a manufatura e distribuição dos insumos para a unidade produtiva rural, as operações produtivas na unidade produtiva como tal, e armazenagem, processamento e distribuição dos produtos rurais e de seus subprodutos. $^{257}$

Assim, conforme leciona Liz Sass ${ }^{258}$, a cadeia agroindustrial é formada por diversos atores "que se inter-relacionam e interagem constantemente" e podem estar em três setores distintos.

No primeiro deles, o qual corresponde ao montante da produção agropecuária, também denominado "antes da porteira”, situam-se os fornecedores de matérias primas e insumos tais quais sementes, implementos agrícolas, tecnologias, financiamentos, dentre outros.

Já no segundo, que corresponde à produção agropecuária propriamente dita ou "dentro da porteira", estão os produtores "os quais são

\footnotetext{
${ }^{256}$ STEIGLEDER,op. cit., p. 224 e 225.

${ }^{257}$ LAUSCHNER, Roque. Industrialização dos Produtos Agrícolas. Perspectiva Econômica. São Leopoldo, vol. 11, nº 33, 1981. p. 156. apud SASS, Liz Beatriz. A Relação entre a Agroindústria e o Produtor Integrado diante do Dano Ambiental: Uma análise a partir da Responsabilidade Civil. In BENJAMIN, Antônio Herman; LECEY, Eladio; CAPPELLI, Sílvia (orgs.). Congresso Internacional de Direito Ambiental. Meio Ambiente e acesso à justiça: flora, reserva legal e APP. V.1. São Paulo: Imprensa Oficial do Estado de São Paulo, 2007. p.424.

${ }^{258}$ SASS, Liz Beatriz. A Relação entre a Agroindústria e o Produtor Integrado diante do Dano Ambiental: Uma análise a partir da Responsabilidade Civil. In BENJAMIN, Antônio Herman; LECEY, Eladio; CAPPELLI, Sílvia (orgs.). Congresso Internacional de Direito Ambiental. Meio Ambiente e acesso à justiça: flora, reserva legal e APP. V.1. São Paulo: Imprensa Oficial do Estado de São Paulo, 2007. p.424.
} 
os agentes cuja função é proceder ao uso da terra para a produção de commodities" tais quais a criação de animais, produção de cereais, madeira, dentre outros e envolvendo ainda o preparo do solo, a colheita, irrigação, etc.

No terceiro setor, chamado de jusante da produção agropecuária, ou “depois da porteira", encontram-se os processadores, representados pela agroindústria, os atacadistas, os varejistas e os consumidores.

Deste modo, Sass demonstra que o complexo agroindustrial surge sob uma visão sistêmica na qual

seus agentes interagem constantemente entre si bem como se encontram sobre a influencia de dois ambientes distintos: o ambiente organizacional, no qual a cadeia agroindustrial está sob a influência dos órgãos ambientais, entre outros; e o ambiente institucional, perante o qual se impõe a observância de normas ambientais, entre outras. ${ }^{259}$

Considerando tal panorama, tem-se que a agroindústria, no desenvolvimento de seu produto, não realiza atividades apenas dentro das empresas industriais, mas relaciona-se com os demais atores dentre os quais se encontra o poluidor integrado.

Ademais, ensina Sass que, na medida em que a agroindústria moderniza o complexo rural, ela se torna o principal mercado dos produtores rurais, vez que necessita concentrar as atividade e garantir as matérias primas de forma planejada, regular e dentro de determinados padrões de qualidade, estabelecendo-se, para tanto, contratos específicos entre a agroindústria e o produtor ${ }^{260}$.

Observa-se, portanto, que

a atividade desenvolvida pelo produtor constitui uma extensão das atividades da agroindústria, que retira seu lucro do que nela é produzido e criado. Aliás, a crescente conscientização quanto à necessidade de exigir posturas ecologicamente corretas das empresas tem influenciado a busca por certificações ambientais, no que se compreende que a agroindústria deve apresentar preocupação com toda a cadeia de produção de sua atividade. ${ }^{261}$

\footnotetext{
${ }^{259}$ Ibid. p. 425 .

${ }^{260}$ Ibid. p. 425 .

${ }^{261}$ Ibid. p. 426 .
} 
Tendo em vista a) a estreita relação entre o produtor integrado e a agroindústria, sendo as atividades desta consideradas extensão das atividades daquele, e b) a possibilidade de responsabilização não só do poluidor direto, mas também do poluidor indireto, prevista no art. $3^{\circ}$, inciso IV, da Lei $n^{\circ}$. 6.938/81, tem-se que, de acordo com previsão legal, poderá a agroindústria ser considerada solidária e indiretamente responsável pelo dano ambiental no âmbito da propriedade do produtor integrado vez que, além de ser beneficiaria desta atividade, é ainda, a sua força motriz, "restando afastada a consideração de quaisquer responsabilidades contratuais assumidas entre os poluidores perante terceiros". ${ }^{262}$

Conclui-se então que, tendo em vista a adoção do regime da responsabilidade civil objetiva, quando se trata de danos ambientais, não se perquirindo a existência de culpa (lato sensu), não poderá a agroindústria eximir-se da sua co-responsabilidade sob a alegação de ausência de dolo, negligencia, imprudência ou imperícia, não cabendo ainda alagação de que a atividade era licenciada vez que, conforme estudado anteriormente, a licença apenas retira o caráter de ilicitude administrativa do ato, não afastando a obrigatoriedade de reparação do dano ambiental.

\subsection{A responsabilização dos produtores e fornecedores pela destinação final dos resíduos: a responsabilidade pós- consumo}

"Desde o seu primeiro momento no Planeta, o homem começou a gerar resíduos com suas atividades" ${ }^{263}$. Assim, os resíduos das atividades humanas "passaram a fazer parte da existência do homem, que começou a utilizar, transformar e modificar os recursos naturais disponíveis em cada

\footnotetext{
262 Ibid. p.434 e 435.

${ }^{263}$ DIAS, Jefferson Aparecido; MORAES FILHO, Ataliba Monteiro de. Os resíduos sólidos e a responsabilidade ambiental pós-consumo. Disponível em <www.prsp.mpf.gov.br/marilia>. Acesso em 12 nov. 2007. p. 5.
} 
momento da evolução"264. Percebe-se, portando, que a história do próprio homem confunde-se com a história dos resíduos ${ }^{265}$.

Em um primeiro momento, os resíduos ${ }^{266}$ eram considerados irrelevantes tendo em vista que a própria natureza acabava por reabsorvêlos e reincorporá-los. Contudo, se paulatinamente tal situação foi sendo modificada, após a Revolução Industrial, com a melhoria da tecnologia empregada, com o crescimento populacional, com o investimento nas novas técnicas de produção em massa, com o crescente consumo e, consequentemente, com um "aumento significativo no volume dos resíduos gerados" 267 , a questão ambiental tornou-se crítica e a adequada destinação do lixo tornou-se um desafio para a humanidade. ${ }^{268}$

Embora tenha prevalecido o entendimento de que "cabe apenas ao Poder Público, principalmente municipal, a destinação adequada dos resíduos sólidos produzidos em seu território" ${ }^{269}$, este não tem conseguido adotar "medidas que seriam adequadas ou mesmo aconselháveis para não provocar ou ao menos minimizar os danos ambientais" 270. Ademais, o ônus da destinação acaba recaindo apenas sobre o Poder Público enquanto as empresas que fornecem ou geram o produto e, consequentemente, “criam" o resíduo, são presenteadas com o lucro de sua negligência com o meio ambiente.

Tendo em vista o panorama exposto, e a possibilidade trazida pelo art. $14, \S 1^{\circ}$ e art. $3^{\circ}$, inciso IV da Lei $\mathrm{n}^{\mathrm{o}} .6 .938 / 81$, de se responsabilizar objetivamente e solidariamente poluidor direto e o poluidor indireto, o sistema brasileiro tem-se aberto para a responsabilização pós-consumo (“ou responsabilidade pelo ciclo total do produto ou responsabilidade estendida

\footnotetext{
${ }^{264}$ Ibid. p. 5.

${ }^{265}$ Ibid. p. 5.

266 A doutrina pátria não é pacífica quanto a distinção entre resíduos sólidos e lixo. Para uns, ambos os termos são sinônimos. Para outros, há diferença entre um termo e outro, sendo o lixo composto por objetos que não possuem qualquer tipo de valor ou utilidade enquanto o resíduo sólido possui valor econômico agregado possibilitando seu reaproveitamento no processo produtivo. (Ibid. p. 9). Neste trabalho, tomaremos ambos os termos como sinônimo.

${ }^{267}$ Ibid. p. 6.

${ }^{268}$ Ibid. p. 5 e 6.

${ }^{269}$ Ibid. p. 7.

${ }^{270}$ Ibid. p. 7.
} 
do produtor" ${ }^{271}$ ), "imposta a determinadas fontes geradoras, em virtude do fator de risco intrínseco do produto" 272 .

Assim,

"pela responsabilidade pós-consumo, fabricantes, comerciantes e importadores devem ser responsabilizados pelo ciclo total de suas mercadorias, do "nascimento" a sua "morte", procedendo à destinação final ambientalmente correta, mesmo após o uso pelo consumidor final, já que a disposição inadequada de seus produtos constitui uma grande fonte de poluição para o meio ambiente e um grande ônus para o Poder Público." ${ }^{273}$

Deste modo, cada empresa deverá assumir a responsabilidade na proporção em que afeta o meio ambiente equilibrado. Para tanto, quando se trata de responsabilização pós-consumo, o Pode Público pode ser valer do princípio do poluidor-pagador obrigando a atividade empresarial a internalizar os custos referentes à produção e aos recursos ambientais utilizados, inclusive os recursos ambientais, tais quais o solo utilizado para estocagem dos resíduos ${ }^{274}$.

Há que se acrescentar ainda que, com a internalização dos custos, as preocupações ambientais passam a estar na pauta das decisões econômicas das empresas incentivando assim o investimento no desenvolvimento de tecnologias que permitam agregar valor às embalagens ou produtos mesmo após a sua utilização pelo consumidor. Com isto, impede-se que os danos ambientais hoje produzidos sejam suportados pelas futuras gerações. ${ }^{275}$

De acordo com Dias \& Moraes Filho, para que seja implementada a responsabilidade pós-consumo, deve o Poder Público intervir na livre iniciativa sob o fundamento de que, de acordo com o art. 170, inciso VI, da Carta Magna, deve a ordem econômica assegurar a todos uma existência digna observando o princípio da defesa do meio ambiente. ${ }^{276}$

De fato, com a redação modificada pela Emenda Constitucional $n^{\circ}$. 42, de 19 de dezembro de 2003, assim dispõe o referido artigo:

\footnotetext{
${ }^{271}$ Ibid. p. 7.

${ }^{272}$ STEIGLEDER, op. cit, p. 204.

${ }^{273}$ DIAS; MORAES FILHO, op. cit., p. 32

${ }^{274}$ Ibid. 33 e 34.

${ }^{275}$ Ibid. 35.

${ }^{276}$ Ibid. 36
} 
Art. 170. A ordem econômica, fundada na valorização do trabalho humano e na livre iniciativa, tem por fim assegurar a todos existência digna, conforme os ditames da justiça social, observados os seguintes princípios:

VI - defesa do meio ambiente, inclusive mediante tratamento diferenciado conforme o impacto ambiental dos produtos e serviços e de seus processos de elaboração e prestação.

Percebe-se, portanto, ser inegável o papel conferido ao Estado de fiscalizar a atuação da atividade econômica sob pena de se omitir quanto ao dever de preservar o meio ambiente equilibrado, tal qual prevê o art. 225 da Constituição Federal de 1988.

Conforme leciona Steigleder, "essa forma de responsabilização já se encontra normatizada em relação aos agrotóxicos, pneus, pilhas e baterias de telefone celular" 277 .

Por meio do art. $6^{\circ}, \S 5^{\circ}$, da Lei Federal $n^{\circ}$. 7.802/89, incluído pela Lei $n^{\circ} .9 .974$ de 2000,

As empresas produtoras e comercializadoras de agrotóxicos, seus componentes e afins, são responsáveis pela destinação das embalagens vazias dos produtos por elas fabricados e comercializados, após a devolução pelos usuários, e pela dos produtos apreendidos pela ação fiscalizatória e dos impróprios para utilização ou em desuso, com vistas à sua reutilização, reciclagem ou inutilização, obedecidas as normas e instruções dos órgãos registrantes e sanitário-ambientais competentes.

No mesmo sentido, dispõe o Decreto Federal n ${ }^{\circ}$. 4.074/2002 e a Lei do Estado do Rio Grande do Sul, de nº 9.921/93, regulamentada pelo decreto $\mathrm{n}^{\text {o }} 38.356$ de 1998, impondo aos fabricantes, importadores e comerciantes de agrotóxicos a responsabilidade pela destinação ambiental correta das embalagens colocadas no mercado. ${ }^{278}$

Com relação aos pneus e às pilhas e baterias de telefones celulares, a regulamentação foi dada pelas Resoluções $n^{\circ} .258$ e 257 do CONAMA.

Ademais, quando se trata de pilhas que contenham mercúrio metálico, lâmpadas fluorescentes, baterias de telefone celular e demais artefatos que contenham metais pesados, no Estado do Rio Grande do Sul a

\footnotetext{
${ }^{277}$ STEIGLEDER, op. cit., p. 204 e 205.

${ }^{278}$ DIAS; MORAES FILHO, op.cit., 36 e 37.
} 
regulamentação é prevista pela Lei no ${ }^{\circ} 11.019$, de 23 de setembro de 1997, com redação alterada pela Lei no . 11.187/98.

Por sorte, tamanha preocupação parece também ter chegado ao Poder Judiciário, tendo o Tribunal de justiça do Estado do Paraná decidido em sede de apelação cível que

A chamada responsabilidade pós-consumo no caso de produtos de alto poder poluente, como as embalagens plásticas, envolve o fabricante de refrigerantes que delas se utiliza, em ação civil pública, pelos danos ambientais decorrentes. Esta responsabilidade é objetiva nos termos da Lei $n^{\circ} 7347 / 85$, artigos $1^{\circ}$ e $4^{\circ}$ da Lei Estadual $n^{\circ} 12.943 / 99$, e artigos $3^{\circ}$ e $14, \S 1^{\circ}$ da Lei $n^{\circ} 6.938 / 81$, e implica na sua condenação nas obrigações de fazer, a saber: adoção de providências em relação a destinação final e ambientalmente adequada das embalagens plásticas de seus produtos, e destinação de parte dos seus gastos com publicidade em educação ambiental, sob pena de multa ${ }^{279}$.

Tal precedente rompe com os preceitos tradicionais vez que, ainda que não tenha diretamente depositado as embalagens no meio ambiente, é o fabricante responsabilizado pelo seu recolhimento e destinação final tendo em vista que a simples existência do produto será responsável pela exposição da sociedade ao risco, passando a ser fator de risco e condição para a ocorrência do dano ambiental. ${ }^{280}$

Conforme demonstrado, embora ainda não seja satisfatória, a responsabilização pós-consumo vem sendo implementada tanto pelo

\footnotetext{
${ }^{279}$ TJPR, AC 0118652-1, 8a Câmara.Cível, Rel Des. Ivan Bortoleto - Unanime - J. 05.08.2002. consta na ementa: AÇÃO CIVIL PÚBLICA - DANO AMBIENTAL - LIXO RESULTANTE DE EMBALAGENS PLÁSTICAS TIPO "PET" (POLIETILENO TEREFTALATO) - EMPRESA ENGARRAFADORA DE REFRIGERANTES - RESPONSABILIDADE OBJETIVA PELA POLUIÇÃO DO MEIO AMBIENTE - ACOLHIMENTO DO PEDIDO - OBRIGAÇÕES DE FAZER - CONDENAÇÃO DA REQUERIDA SOB PENA DE MULTA - INTELIGÊNCIA DO ARTIGO 225 DA CONSTITUIÇÃO FEDERAL, LEI No $7347 / 85$, ARTIGOS $1^{\circ}$ E $4^{\circ}$ DA LEI ESTADUAL No $12.943 / 99,3^{\circ}$ e $14, \S 1^{\circ}$ DA LEI ${ }^{\circ} 6.938 / 81$ - SENTENÇA PARCIALMENTE REFORMADA. Apelo provido em parte. 1. Se os avanços tecnológicos induzem o crescente emprego de vasilhames de matéria plástica tipo "PET" (polietileno tereftalato), propiciando que os fabricantes que delas se utilizam aumentem lucros e reduzam custos, não é justo que a responsabilidade pelo crescimento exponencial do volume do lixo resultante seja transferida apenas para o governo ou a população. 2. A chamada responsabilidade pós-consumo no caso de produtos de alto poder poluente, como as embalagens plásticas, envolve o fabricante de refrigerantes que delas se utiliza, em ação civil pública, pelos danos ambientais decorrentes. Esta responsabilidade é objetiva nos termos da Lei $\mathrm{n}^{\circ} 7347 / 85$, artigos $1^{\circ}$ e $4^{\circ}$ da Lei Estadual $\mathrm{n}^{\circ}$ $12.943 / 99$, e artigos $3^{\circ}$ e $14, \S 1^{\circ}$ da Lei $n^{\circ} 6.938 / 81$, e implica na sua condenação nas obrigações de fazer, a saber: adoção de providências em relação a destinação final e ambientalmente adequada das embalagens plásticas de seus produtos, e destinação de parte dos seus gastos com publicidade em educação ambiental, sob pena de multa.

${ }^{280}$ STEIGLEDER, op. cit., 205.
} 
legislador quanto pelo poder judiciário, sendo medida eficaz e de extrema importância para manutenção e preservação do meio ambiente. 


\section{Conclusão}

Quando o ser humano passou a sentir os efeitos de seu desenvolvimento desenfreado, no qual o meio ambiente era visto apenas como um recurso que possibilitava a sua "evolução", percebeu que na esgotabilidade desta matéria prima estaria sua estagnação, quando não, seu retrocesso.

Assim, tomado pelo pensamento antropocêntrico de que o meio ambiente deveria ser protegido para que, consequentemente, não houvesse paralisação no "progresso", deu-se o início de uma era de medidas legais que visavam a proteção do mesmo.

Com o passar do tempo, alterando tal visão, na qual a preservação deste "bem" possuía como finalidade principal o bem-estar do ser humano, passou-se a admitir a proteção do meio ambiente em si mesmo considerado, iniciando assim a conservação efetiva deste meio ambiente autônomo.

Neste contexto, a Constituição Federal de 1988 previu em seu art. 225 , caput, que o meio ambiente ecologicamente equilibrado, bem de uso comum do povo, é direito garantido às presentes e futuras gerações, devendo ser protegido, tanto pelo poder público quanto pela coletividade. Por isso, sua apropriação, como macrobem, passa a ser vetada aos particulares os quais, apenas poderão apoderar-se dos recursos ambientais e, ainda assim, respeitados os limites previstos em lei.

Dentre outros meios para efetivar tal proteção, a responsabilização civil dos agentes poluidores merece destaque possuindo função não somente reparatória, mas também preventiva.

Todavia, quando se trata de lesão ao meio ambiente, tendo em vista a ausência dos requisitos rígidos para a reparação dos danos, tais quais certeza, atualidade, pessoalidade e a demonstração de um liame causal adequado entre o resultado e a atividade, como ocorre na responsabilidade civil tradicional, fez-se necessária a adaptação deste instituto de modo que a dificuldade de valoração do dano ambiental e de estabelecimento no nexo 
causal, a pluralidade de agentes poluidores e difusidade das vítimas não se tornassem óbices intransponíveis para a reparação.

Dentre estas adaptações, encontra-se a ampliação do rol dos agentes poluidores que passa a incluir não apenas aqueles de diretamente ensejaram o resultado lesivo, mas também, nos moldes do art. $3^{\circ}$, inciso IV, da Lei $n^{\circ}$. 6938/81, aqueles que de forma indireta contribuíram para o dano ambiental.

Em conjunto com tal ampliação do rol de sujeitos passivos de uma ação reparatória ambiental, o ordenamento jurídico vigente optou pelo regime da responsabilidade civil objetiva, não se perquirindo, portanto, a culpa (lato sensu) do agente poluidor. Com isto, substituindo-se a teoria da culpa, presente na responsabilidade civil subjetiva tradicional, pela teoria do risco, tem-se que, de acordo com a modalidade adotada - risco integral ou criado - e, dependendo da teoria do nexo causal escolhida - teoria da equivalência dos antecedentes ou causalidade adequada - flexibilizando mais ou menos o liame de causalidade, admitindo-se ou não as excludentes de responsabilidade - culpa exclusiva da vítima, fato de terceiro, caso fortuito e força maior -, pode-se chegar a resultados que firam a segurança jurídica ou, de outro modo, que mitiguem os objetivos maiores do instituto, quais sejam a preservação do meio ambiente e a reparação dos danos ambientais.

Ademais, há que se considerar ainda não ser pacífica na doutrina e nem na jurisprudência a amplitude dos riscos que originam a responsabilidade civil ambiental, não havendo sequer um parâmetro preciso acerca da diferenciação entre as modalidades.

Assim, em um dos extremos, flexibilizando demasiadamente o nexo causal e não se admitindo as excludentes de responsabilidade, seria possível a responsabilização infinita da cadeia de poluidores. Por outro lado, no outro extremo, tornando rígido o nexo causal e admitindo-se as excludentes, o resultado, também indesejado, seria a irreparabilidade dos danos ambientais. 
Deste modo, considerar responsável o poluidor indireto, tal como fez $o$ art. $3^{\circ}$, inciso IV, da Lei $\mathrm{n}^{\circ}$. 6938/81, sem que se delimite a abrangência de tal conceito e sem que se estabeleça a modalidade do risco e a teoria da causalidade adotada, é fazer pairar sobre toda a coletividade uma grande insegurança jurídica.

Há que se ressaltar que a grande problemática não diz respeito ao Estado como poluidor indireto e, tampouco, à co-responsabilidade das instituiçõos financeiras, situações amplamente discutidas e abordadas tanto pela jurisprudência quanto pela doutrina. O problema é mais profundo residindo em se saber qual será o limite para a responsabilização de um poluidor indireto. Novas possibilidades sempre surgem assim como a possibilidade de responsabilização da agroindústria por danos causados pelo produtor integrado e a responsabilização pós-consumo.

Assim, resta a questão: quem poderá ser considerado poluidor indireto para fins de responsabilização civil pelo dano ambiental?

Vez que nenhuma das teorias apresentadas oferece respostas prontas que satisfaçam tanto à necessidade de reparação do dano ambiental quanto à necessidade de segurança jurídica, servindo apenas como um roteiro para o desenvolvimento de um raciocínio lógico na busca de uma solução, tal indagação encontra-se longe de ser resolvida, cabendo, portanto, um estudo mais aprofundado pela doutrina sobre quem poderá figurar no pólo passivo de uma ação reparatória ambiental.

Por enquanto, restará nas mãos dos doutos julgadores a solução para o referido problema, devendo os mesmos, utilizando-se dos princípios da razoabilidade, bom-senso, probabilidade e equidade, bem como se valendo das melhores contribuições das teorias existentes, examinar, com base nas provas produzidas no curso do processo, o caso concreto. 


\section{Referências Bibliográficas:}

ANTUNES, Paulo de Bessa. Dano Ambiental: Uma Abordagem conceitual. Rio de Janeiro: Editora Lumen Juris, 2000. 329 p.

Dano Ambiental: A manifestação da vontade de repará-lo como causa da suspensão de aplicação de penalidades administrativas. In Revista de Direito Ambiental, São Paulo, n. 7, p. 110-118, 1997.

ATHIAS, Jorge Alex Nunes. Responsabilidade Civil e Meio Ambiente breve panorama do direito brasileiro. In BENJAMIN, Antonio Herman (coord.). Dano ambiental: prevenção, reparação e repressão. São Paulo: Editora Revista dos Tribunais, 1993. p. 237-249

BARBOSA, Rangel; OLIVEIRA, Patrícia. O princípio do poluidor-pagador no protocolo de Quioto. Revista de Direito Ambiental, São Paulo, n. 44, p.112-132, 2006.

BARROSO, Luís Roberto. A proteção do meio ambiente na Constituição Brasileira. O direito ambiental e o novo humanismo ecológico. Revista de Direito da Procuradoria Geral, Rio de Janeiro, n. 44, p. 41-75, 1992.

BENJAMIN, Antônio Herman. Responsabilidade civil pelo dano ambiental. Revista de Direito Ambiental, São Paulo, v.9, ano3, p.5-52, jan./mar. 1998.

O Princípio Poluidor-Pagador e a Reparação do Dano Ambiental. In BENJAMIN, Antonio Herman (coord.). Dano ambiental: prevenção, reparação e repressão. São Paulo: Editora Revista dos Tribunais, 1993. p.226-236

BESSA, Leonardo Roscoe. Dano Moral Coletivo. In BENJAMIN, Antônio Herman; LECEY, Eladio; CAPPELLI, Sílvia (orgs.). Congresso 
Internacional de Direito Ambiental. Meio Ambiente e acesso à justiça: flora, reserva legal e APP. V.3. São Paulo: Imprensa Oficial do Estado de São Paulo, 2007. p. 175-200.

BIRNFELD, Carlos André. Algumas Perspectivas sobre a Responsabilidade Civil do Poluidor por Danos Ambientais. In LEITE, José Rubens Morato BELLO FILHO; Ney de Barros (orgs.). Direito Ambiental Contemporâneo. São Paulo: Manole, 1997. p. 357-378.

BORGES, Roxana Cardoso Brasileiro. Direito ambiental e Teoria Jurídica no final do século XX. In VARELLA, Marcelo Dias e BORGES, Roxana Cardodo (orgs.). O novo em Direito Ambiental. Belo Horizonte: Del Rey, 1998.

BUGLIONE, Samantha. O desafio de tutelar o meio ambiente. Revista de Direito Ambiental, São Paulo, n. 17, p. 194-220, 2000.

CAFFERATTA, Nestor A. Prueba y Nexo de Causalidad em el Dano Ambiental. In BENJAMIN, Antônio Herman; LECEY, Eladio; CAPPELLI, Sílvia (orgs.). Congresso Internacional de Direito Ambiental. Meio Ambiente e acesso à justiça: flora, reserva legal e APP. V.3: São Paulo: Imprensa Oficial do Estado de São Paulo, 2007. p. 265-309.

CANOTILHO, J. J. Gomes. A responsabilidade por danos ambientais: aproximação juspublicística. In AMARAL, Diogo de Freitas do (coord.). Direito do Ambiente. Oeiras: Instituto de Administração, 1994. p.397-408.

CARVALHO, Délton Winter de. Dano ambiental futuro: a responsabilização civil pelo risco ambiental. Revista de Direito Ambiental, São Paulo, n. 45, p. 62-91, 2007. 
CARVALHO FILHO, José dos Santos. Manual de direito Administrativo. $17^{\mathrm{a}}$ edição. Rio de Janeiro: Editora Lumen Juris , 2007. 1056 p.

CAVALIERI FILHO, Sergio. Programa de Responsabilidade Civil. $7^{\mathrm{a}}$ ed. São Paulo: Atlas, 2007. 561 p.

COSTA NETO, Nicolao Dino de Castro e. Proteção Jurídica do meio ambiente. I-Florestas. Belo Horizonte: Del Rey, 2003. 407 p.

CRUZ, Branca Martins da. Responsabilidade civil pelo dano ecológico: Alguns problemas. Revista de Direito Ambiental, São Paulo, n. 5, p. 5-41, 1997.

Avanços e Retrocessos do Direito Ambiental na União Européia: análise crítica da Proposta de Diretiva sobre Responsabilidade Ambiental. In LEITE, José Rubens Morato BELLO FILHO; Ney de Barros (orgs.). Direito Ambiental Contemporâneo. São Paulo: Manole, 1997. p. 1-50.

DIAS, Jefferson Aparecido; MORAES FILHO, Ataliba Monteiro de. Os resíduos sólidos e a responsabilidade ambiental pós-consumo. Disponível em <www.prsp.mpf.gov.br/marilia>. Acesso em 12 nov. 2007.

FERRAZ, Sérgio. Responsabilidade civil pelo dano ecológico. Revista de Direito Público, São Paulo, n. 49/90, 1979.

FLORES, Manuela. Responsabilidade civil ambiental em Portugal: Legislação e Jurisprudência. Revista de Direito Ambiental, São Paulo, n. 11, p. $75-92,1998$.

FRANCO, Andréa Silveira Santana. A Responsabilidade Civil Ambiental do Novo Adquirente de Reserva Legal Degradada Ambientalmente. In 
BENJAMIN, Antônio Herman; LECEY, Eladio; CAPPELLI, Sílvia (orgs.). Congresso Internacional de Direito Ambiental. Meio Ambiente e acesso à justiça: flora, reserva legal e APP. V.2. São Paulo: Imprensa Oficial do Estado de São Paulo, 2007. p. 93-109.

FREITAS, Vladimir Passos de. O Poder Judiciário e o Direito Ambiental no Brasil. In BENJAMIN, Antônio Herman; LECEY, Eladio; CAPPELLI, Sílvia (orgs.). Congresso Internacional de Direito Ambiental. Meio Ambiente e acesso à justiça: flora, reserva legal e APP. V.3. São Paulo: Imprensa Oficial do Estado de São Paulo, 2007. p. 413-429.

GONÇALVES, Carlos Roberto. Direito Civil Brasileiro. V.IV: responsabilidade civil. São Paulo: Saraiva, 2007. 533 p.

GRECO, Leonardo. Competências constitucionais em matéria ambiental. Revista dos Tribunais, São Paulo, n. 687, p. 23-33, 1993.

HAMMERSCHMIDT, Denise. O risco na sociedade contemporânea e o princípio da precaução no direito ambiental. Revista de Direito Ambiental, São Paulo, n. 31, p. 136-156, 2003.

JUCOVSKY, Vera Lúcia Rocha Souza. Estado - Ambiente e danos ecológicos Brasil e Portugal. Revista de Direito Ambiental, São Paulo, n. 11, p. 93-92, 1998.

Responsabilidade civil do estado por danos ambientais no Brasil e em Portugal. Revista de Direito Ambiental, São Paulo, n. 12, p. 26-67, 1998.

KRELL, Andréas Joachim. Concretização do dano ambiental: objeções à teoria do risco integral. Revista de Informação Legislativa, Brasília, v. 139, 1998. p.22-37. 
LAMAC, Jaques. Responsabilidade Ambiental do Estado: Aspectos Administrativos. In Revista de Direitos Difusos, São Paulo, ano IV, v. 17, p. 2271-2290, 2003.

LANFREDI, Geraldo Ferreira. A objetivação da teoria da responsabilidade civil e seus reflexos nos danos ambientais ou no uso anti-social da propriedade. Revista de Direito Ambiental, n. 6, p. 87-96, 1997.

LEITE, José Rubens Morato. Dano Ambiental: do individual ao coletivo extrapatrimonial. São Paulo: Editora Revista dos Tribunais, 2000. 344 p.

LEME MACHADO, Paulo Affonso. Direito Ambiental Brasileiro. 15 edição. São Paulo: Malheiros 2007. 1111 p.

Paulo Affonso. O Princípio da Precaução e o Direito Ambiental. Revista de Direitos Difusos, São Paulo, v. 8, 2001.

LEUZINGER, Márcia Dieguez. Responsabilidade civil do Estado por danos ao meio ambiente. Revista de Direito Ambiental, São Paulo, n. 45, p. 184$195,2007$.

LOUBET, Luciano Furtado. Delineamento do dano ambiental: o mito do dano por ato lícito. Revista de Direito Ambiental, São Paulo, n. 40, p. 124$147,2005$.

LYRA, Marcos Mendes. Dano Ambiental. Revista de Direito Ambiental, São Paulo, n. 8, p. 49-83, 1997. 
MARCONDES, Ricardo Kochinski. BITTENCOURT, Darlan Rodrigues. Lineamentos da responsabilidade civil Ambiental. Revista de Direito Ambiental, São Paulo, n. 3, p. 108-149,1996.

MÁRQUEZ, José Juan González. De la Responsabilidad Aquiliana a La Responsabilidad Sin Dano. Una Propuesta para América del Norte. In BENJAMIN, Antônio Herman; LECEY, Eladio; CAPPELLI, Sílvia (orgs.). Congresso Internacional de Direito Ambiental. Meio Ambiente e acesso à justiça: flora, reserva legal e APP. V.3: 137-149. São Paulo: Imprensa Oficial do Estado de São Paulo, 2007.

MARTINS, Ricardo Marcondes. Regime jurídico da licença ambiental. Revista de Direito Ambiental. São Paulo, n. 40, p. 186-216, 2005.

MELLO, Celso Antônio Bandeira de. Curso de Direito Administrativo. $18^{\mathrm{a}}$ edição. São Paulo: Malheiros Editores, 2005. 1008 p.

MICHELS, Ruanda Schlickmann. Instrumentos administrativos de prevenção ao dano ambiental. Revista de Direito Ambiental, São Paulo, n. 45, p. 213-232, 2007.

MILARÉ, Edis. Direito do Ambiente. $5^{\mathrm{a}}$ edição ref., atual. e ampl. São Paulo: Revista dos Tribunais, 2007. 1280 p.

; LOURES, Flavia Tavares Rocha. O papel do terceiro setor na proteção jurídica do ambiente. Revista de Direito Ambiental, São Paulo, n. 35, p. 96-122, 2004.

MIRRA, Álvaro Luiz Valery. Ação civil pública e reparação do dano ao meio ambiente. $2^{\mathrm{a}}$ edição. São Paulo: Juarez de Oliveira 2004. 428 p. 
. Proteção do meio ambiente: a omissão do poder público e o papel social do Judiciário no controle da administração pública. Revista de Direito Ambiental, São Paulo, n. 30, p. 35-44, 2003.

A Noção de Poluidor na Lei no 6938/84 e a Questão da Responsabilidade solidária do Estado pelos Danos Ambientais Causados por Particulares. In MORATO LEITE, José Rubens; DANTAS, Marcelo Buzaglo (Orgs.). Aspectos Processuais do Direito Ambiental. Rio de Janeiro: Forense Universitária, 2003.

- Responsabilidade civil pelo dano ambiental e o princípio da reparação integral do dano. Revista de Direito Ambiental, São Paulo, n. 32, p. $68-82,2003$.

Direito Ambiental: o princípio da precaução e sua aplicação judicial. Revista de Direito Ambiental, São Paulo, n. 21, p. 92-102, 2001.

.Princípios fundamentais do direito ambiental. Revista de Direito Ambiental, São Paulo, n. 2, p. 50-66, 1996.

.Fundamentos do Direito Ambiental no Brasil. Revista dos Tribunais, São Paulo, v. 706, p. 7-29, 1994.

MORAES, Maria Celina Bodin de. O princípio da solidariedade. In PEIXINHO, Manoel Messias; GUERRA, Isabela Franco; NASCIMENTO FILHO, Firly (orgs.). Os princípios da Constituição de 1988. $2^{\mathrm{a}}$ edição. Rio de Janeiro: Lúmen Júris, 2006.

MUKAI, Toshio. Direito Ambiental Sistematizado. 4. ed. Rio de Janeiro: Forense Universitária, 2002. 214 p. 
NAVES NETO, Ronan Cardoso. A Aplicação de Excludentes de Responsabilidade Civil em Casos de Danos Ambientais e a Adoção da Teoria do Risco Criado como a Melhor Forma de se Efetivar os Princípios da Segurança Jurídica e da Prevenção. In BENJAMIN, Antônio Herman; LECEY, Eladio; CAPPELLI, Sílvia (orgs.). Congresso Internacional de Direito Ambiental. Meio Ambiente e acesso à justiça: flora, reserva legal e APP. V.3. São Paulo: Imprensa Oficial do Estado de São Paulo, 2007. p. $755-766$.

NERY JUNIOR, Nelson; NERY, Rosa Maria B. B. de Andrade. Responsabilidade Civil, Meio ambiente e Ação Coletiva Ambiental. In BENJAMIN, Antonio Herman (coord.). Dano ambiental: prevenção, reparação e repressão. São Paulo: Editora Revista dos Tribunais, 1993. p. $278-307$

OLIVEIRA, Alexandre Vidigal de. Proteção Ambiental em Juízo. Omissão administrativa - Questões relevantes. Revista de Direito Ambiental, São Paulo, n. 7, p. 132-136, 1997.

OLIVEIRA JÚNIOR, Zedequias de. Responsabilidade Administrativa Objetiva Ambiental: Aspectos jurídico-constitucionais. In BENJAMIN, Antônio Herman; LECEY, Eladio; CAPPELLI, Sílvia (orgs.). Congresso Internacional de Direito Ambiental. Meio Ambiente e acesso à justiça: flora, reserva legal e APP. V.3. São Paulo: Imprensa Oficial do Estado de São Paulo, 2007. p.703-718

PASQUALOTTO, Adalberto. Responsabilidade Civil por Dano Ambiental: Considerações de ordem material e processual. In BENJAMIN, Antonio Herman (coord.). Dano ambiental: prevenção, reparação e repressão. São Paulo: Editora Revista dos Tribunais, 1993. p.444-470 
RIBAS, Luiz César. Os processos de gestão ambiental, de avaliação ambiental e de mensuração de danos ambientais - escopo conceitual. Revista de Direito Ambiental, São Paulo, n. 8, p. 107-131, 1997.

ROCHA, Maria Isabel de Matos. Reparação de danos ambientais. Revista de Direito Ambiental, São Paulo, n. 19, p. 129-156, 2000.

SAMPAIO. Francisco José Marques. Responsabilidade Civil e Reparação de Danos ao Meio Ambiente. $2^{\mathrm{a}}$ edição. Rio de Janeiro: Editora Lumen Juris, 1998. $260 \mathrm{p}$.

O dano ambiental e a responsabilidade. Revista de Direito da Procuradoria Geral, Rio de Janeiro, n. 44, p. 132-154, 1992.

SASS, Liz Beatriz. A Relação entre a Agroindústria e o Produtor Integrado diante do Dano Ambiental: Uma análise a partir da Responsabilidade Civil. In BENJAMIN, Antônio Herman; LECEY, Eladio; CAPPELLI, Sílvia (orgs.). Congresso Internacional de Direito Ambiental. Meio Ambiente e acesso à justiça: flora, reserva legal e APP. V.1. São Paulo: Imprensa Oficial do Estado de São Paulo, 2007. p. 423-438.

SANTILLI, Juliana. A co-responsabilidade das instituições financeiras por danos ambientais e o licenciamento ambiental. Revista de Direito Ambiental, São Paulo, n. 21, p.132-173, 2001.

SIQUEIRA CASTRO, Carlos Roberto de. O direito ambiental e o novo humanismo ecológico. Revista de Direito da Procuradoria Geral, Rio de Janeiro, n. 44, p. 27-40, 1992.

STÉDILE, Luis Otávio. O licenciamento como limitador da Responsabilidade Civil por Dano Ecológico. In BENJAMIN, Antônio 
Herman; LECEY, Eladio; CAPPELLI, Sílvia (orgs.). Congresso Internacional de Direito Ambiental. Meio Ambiente e acesso à justiça: flora, reserva legal e APP. V.3. São Paulo: Imprensa Oficial do Estado de São Paulo, 2007. p. 443-458.

STEIGLEDER, Annelise Monteiro. Responsabilidade civil ambiental: as dimensões do dano ambiental no Direito Brasileiro. Porto Alegre: Livraria do Advogado Editora, 2004. 287 p.

. Considerações sobre o nexo de causalidade na responsabilidade civil por dano ao meio ambiente. Revista de Direito Ambiental, São Paulo, n. 32, p. 83-103, 2003.

- Considerações sobre o nexo de causalidade na responsabilidade civil por dano ao meio ambiente. Revista de Direito Ambiental, São Paulo, n. 32, p. 83-103, 2003.

Áreas contaminadas e a obrigação do poluidor de custear - Um diagnóstico para dimensionar o dano ambiental. Revista de Direito Ambiental, São Paulo, n. 25, p. 59-78, 2002.

TELLES, Eduardo Maccari. A responsabilidade civil do estado por atos omissivos e o novo código civil. Revista de Direito da Procuradoria Geral, rio de Janeiro, n. 57, p. 115-130, 2003.

TENFEN, Daniel Luís. Jurisprudências em Matéria Ambiental: Aspectos característicos. In BENJAMIN, Antônio Herman; LECEY, Eladio; CAPPELLI, Sílvia (orgs.). Congresso Internacional de Direito Ambiental. Meio Ambiente e acesso à justiça: flora, reserva legal e APP. V.3. São Paulo: Imprensa Oficial do Estado de São Paulo, 2007. p. 533-545. 
TOURINHO NETO, Fernando da Costa. O dano ambiental. Revista de Direito Ambiental, São Paulo, n. 3, p. 65-71, 1996.

VITTA, Heraldo Garcia. Da divisão de competências das pessoas políticas e o meio ambiente. Revista de Direito Ambiental, São Paulo, n. 10, p. 93$101,1998$. 